UNIVERSIDADE DE SÃO PAULO

INSTITUTO DE PSICOLOGIA

TAYNÁ SCANDIUZZI DE BRITO

INTERAÇÕES LINGUÍSTICAS ENTRE BEBÊS IRMÃOS DE CRIANÇAS COM TRANSTORNO DO ESPECTRO DO AUTISMO E SUAS MÃES 
UNIVERSIDADE DE SÃO PAULO

INSTITUTO DE PSICOLOGIA

TAYNÁ SCANDIUZZI DE BRITO

\title{
INTERAÇÕES LINGUÍSTICAS ENTRE BEBÊS IRMÃOS DE CRIANÇAS COM TRANSTORNO DO ESPECTRO DO AUTISMO E SUAS MÃES
}

\author{
Dissertação apresentada ao Instituto de \\ Psicologia da Universidade de São Paulo para a \\ obtenção do título de MESTRE em Ciências \\ Área de concentração: Psicologia Escolar e do \\ Desenvolvimento Humano
}

Orientador: Prof. Dr. Rogerio Lerner

São Paulo

2019 
Scandiuzzi de Brito, Tayná

Interações Linguísticas entre bebês irmãos de crianças com Transtorno do Espectro do Autismo e suas mães / Tayná Scandiuzzi de Brito; orientador Rogerio Lerner. - São Paulo, 2019.

$109 \mathrm{f}$.

Dissertação (Mestrado - Programa de Pós-Graduação em Psicologia Escolar e do Desenvolvimento Humano) -- Instituto de Psicologia, Universidade de São Paulo, 2019.

1. desenvolvimento de linguagem. 2. bebês. 3. autismo. 4. irmãos. 5 . desenvolvimento psíquico . I. Lerner, Rogerio, orient. II. Título. 
Scandiuzzi de Brito, Tayná Interações Linguísticas entre bebês irmãos de crianças com Transtorno do Espectro do Autismo e suas mães / Tayná Scandiuzzi de Brito; orientador Rogerio Lerner. - - São Paulo, 2019.

Dissertação apresentada ao Instituto de Psicologia da Universidade de São Paulo para a obtenção do título de MESTRE em Ciências

Área de concentração: Psicologia Escolar e do Desenvolvimento Humano

Orientador: Prof. Dr. Rogerio Lerner

Aprovada em:

Banca Examinadora:

Prof. Dr.:

Instituição: Assinatura:

Prof. Dr.:

Instituição: Assinatura:

Prof. Dr.:

Instituição: Assinatura:

Prof. Dr.:

Instituição: Assinatura: 
Aos meus pais,

Maria Egle e Francisco 


\section{AGRADECIMENTOS}

Ao João, por ser meu companheiro nos pequenos e grandes projetos da vida. Pelo exemplo de dedicação, ética e entusiasmo pela ciência. Obrigada por me acolher, me dar forças e por suas incontáveis contribuições neste trabalho, que não seria o mesmo sem você.

À minha família, pela permanente torcida e todo afeto despendido ao longo de minha vida.

À Lari e Ste, por todo apoio, leitura e sugestões. Nossos encontros semanais ajudaram incontestavelmente na construçãodeste trabalho e mostraram que a distância não é impeditiva nos laços de amizade e nas trocas de conhecimento.

Aos meus amigos queridos, Vanessa, Ni, Pri, Gustavo, Giu, Ju Moreira e Mari, por sempre me escutarem e me acolherem. Sem deixar de esquecer das minhas amigas da faculdade, Camila, Virgínia, Julia e Ana, pelos velhos e novos tempos. A vida é mais colorida ao lado de vocês.

À Prof. Ana Paula Ramos de Souza, por ter se disposto a embarcar neste trabalho comigo, obrigada pelos aprendizados, pelas tantas referências compartilhadas e seu esforço por se fazer presente nas bancas.

À Prof. Julia Durand, pelas contribuições na qualificação e pelas tardes em seu consultório, se dispondo a me auxiliar com o banco de dados.

Às Profas. Maria Cecília Pereira da Silva; Mariângela Mendes de Almeida e Eloísa Lacerda, por me entusiasmarem com o universo dos bebês e estarem sempre disponíveis para compartilharem seus conhecimentos comigo.

À Isabela de Moraes Fattore pela paciência e grande auxilio na codificação do meu banco de dados e ao Vinícius David, pela indispensável ajuda na difícil tarefa da análise estatística.

À Cidinha, pelo apoio, acompanhamento e trocas em psicologia.

Ao Prof. Dr. Rogerio Lerner, por ter me dado a oportunidade de desenvolver este trabalho, pela confiança a mim depositada e pelas sugestões e atenta correção desta dissertação.

À Coordenação de Aperfeiçoamento de Pessoal de Nível Superior (CAPES), pela concessão da bolsa de estudos que tornou possível a execução desta pesquisa. 
Queria que a minha voz tivesse um formato de canto. Porque eu não sou da informática: eu sou da invencionática. Só uso a palavra para compor meus silêncios

(Manoel de Barros) 


\section{RESUMO}

\section{INTERAÇÕES LINGUÍSTICAS ENTRE BEBÊS IRMÃOS DE CRIANÇAS COM TRANSTORNO DO ESPECTRO DO AUTISMO E SUAS MÃES}

Este estudo tem como objetivo verificar se a condição de um bebê possuir um irmão mais velho com Transtorno do Espectro do Autismo (TEA) associa-se a maior ausência de sinais enunciativos de aquisição de linguagem em comparação àqueles bebês que não possuem um irmão com este diagnóstico. O instrumento SEAL (Sinais enunciativos de aquisição de linguagem) foi aplicado em 80 duplas mãebebês, com bebês de até 12 meses e 29 dias, sendo 38 do grupo caso (bebês irmãos de crianças com TEA) e 42 do grupo controle (bebês irmãos de crianças sem TEA). A base de dados é secundária, sendo retirada da pesquisa "Vulnerabilidade de pais e irmãos de crianças com transtorno do espectro autista", com coordenação do Prof. Dr. Rogério Lerner do Instituto de Psicologia da USP. Como objetivos secundários, a presente pesquisa pretendeu averiguar se crianças que foram sinalizadas com dificuldade de desenvolvimento pelo instrumento IRDI (Indicadores de Risco para o Desenvolvimento Infantil) e sinalizadas com retraimento pelo instrumento ADBB (AlarmDistress Baby Scale) também foram aquelas indicadas com dificuldade de linguagem pelo SEAL. Dada uma correlação baixa encontrada, discutiu-se qualitativamente uma vinheta do material filmado de uma dupla mãe-bebê indicada somente pelo SEAL. A discussão teórica se dá a partir de autores com fundamentação da perspectiva enunciativa, da qual o SEAL se baseia, além da teoria de desenvolvimento emocional do psicanalista Donald Winnicott. Encontrou-se nos resultados que bebês da primeira subfaixa de idade ( 2 meses a 6 meses e 29 dias) do grupo caso possuem mais dificuldades de linguagem do que os do grupo controle e que bebês da segunda subfaixa de idade ( 7 meses a 12 meses e 29 dias) do grupo caso possuem menos dificuldades de linguagem, se comparados ao grupo controle, contrariando as expectativas. Além disto, bebês da segunda subfaixa de idade tiveram mais dificuldades de linguagem do que os da primeira subfaixa de idade. Houve consonância entre o IRDI, ADBB e SEAL na primeira subfaixa de idade, indicando que bebês com não dificuldades de desenvolvimento e sem retraimento não possuem também dificuldades de linguagem. Com a vinheta clínica foi possível observar mais atentamente as nuances vocais maternas, competência do bebê e sintonia da dupla. A complexidade em se avaliar uma dupla mãe-bebê em um único momento de filmagem também foi evocada, afirmando a importância de acompanhamento longitudinal das díades. Apesar dos dados inconclusivos para a detecção de dificuldades de linguagem entre os grupos caso e controle na amostra, isto não elimina a necessidade de atenção e cuidados para mãe e bebês irmãos de crianças com TEA. Estudos precisam ser desenvolvidos a fim de fundamentarem melhor a discussão dos instrumentos de linguagem e bebês de irmãos de crianças com TEA.

Palavras-chave: Desenvolvimento de linguagem. Bebês. Autismo. Irmãos. Desenvolvimento Psíquico. 


\section{ABSTRACT \\ LINGUISTIC INTERACTIONS BETWEEN BABIES BROTHERS OF CHILDREN WITH AUTISM SPECTRUM DISORDERS AND THEIR MOTHERS}

This study aims to verify if the condition of a baby with an older brother with Autism Spectrum Disorder (ASD) is associated with a greater absence of enunciative signs of language acquisition in comparison to those infants who do not have a sibling with this diagnosis. The SEAL instrument was applied in 80 double mother-babies, with infants up to 12 months and 29 days, 38 of the case group (infants of children with ASD) and 42 of the control group (infants siblings of children without ASD). The database is secondary, being taken from the research "Vulnerability of parents and siblings of children with autism spectrum disorder", with coordination of Prof. Dr. Rogério Lerner of the Institute of Psychology of USP. As secondary objectives, this study aimed to investigate whether children who were flagged with developmental difficulty by the IRDI instrument (Indicators of Risk for Child Development) and signaled with withdrawal by the ADBB (Alarm Distress Baby Scale) instrument were also those indicated with language difficulty by SEAL. Given a low correlation found, a vignette of the filmed material of a mother-infant indicated only by SEAL was discussed qualitatively. The theoretical discussion is based on authors based on the enunciative perspective, on which the SEAL is based, in addition to the theory of emotional development of the psychoanalyst Donald Winnicott. It was found in the results that infants of the first sub-age group (2 months to 6 months and 29 days) of the group had more language difficulties than those in the control group and that infants of the second sub-age group ( 7 months to 12 months and 29 days) of the group if they have less language difficulties, when compared to the control group, contrary to expectations. In addition, infants of the second sub-age group had more language difficulties than those of the first sub-age group. There was agreement between the IRDI, ADBB and SEAL in the first subage group, indicating that infants with no developmental difficulties and no withdrawal did not also have language difficulties. With the clinical vignette, it was possible to observe more carefully the maternal vocal nuances, the baby's competence and the tune of the pair. The complexity in evaluating a dual-motherbaby in a single moment of filming was also evoked, stating the importance of longitudinal accompaniment of the dyads. Despite the inconclusive data for the detection of language difficulties between the case and control groups in the sample, this does not eliminate the need for attention and care for sibling mothers and infants of children with ASD. Studies need to be developed in order to better inform the discussion of the language instruments and infants of siblings of children with ASD.

Keywords: Language development. Infants. Autism. Siblings. Psychical Development. 
LISTA DE ABREVIATURAS E SIGLAS

\begin{tabular}{ll} 
ADBB & Alarm Distress Baby Scale \\
ASHA & American Speech - Language - Hearing Association \\
CAPSi & Centro de Atenção Psicossocial Infantil \\
CIB & Coding Interective Behavior \\
CID - 10 & Classificação Internacional de Doenças - 10 \\
DD & Dificuldade de Desenvolvimento \\
DL & Dificuldade de Linguagem \\
DSM & Manual Diagnóstico de Doenças Mentais \\
GFTA-2 & Goldman-Fristoe Test of Articulation 2 \\
IRDI & Indicadores de Risco para o Desenvolvimento Infantil \\
M-Chat & Modified Chacklist foi Autism in Toodlers \\
TEA & Transtorno do Espectro do Autismo \\
NE-DD & Não - Dificuldade de Desenvolvimento \\
N-DL & Não - Dificuldade de Linguagem \\
R & Retraimento \\
\hline
\end{tabular}




\section{LISTA DE QUADROS}

Quadro 1. Sinais Enunciativos de Aquisição de Linguagem (Crestani, 2016).......... p. 62

Quadro 2. Indicadores de Risco para o Desenvolvimento Infantil (Kupfer, 2008).... p. 65 


\section{LISTA DE TABELAS}

Tabela 1. Contagem (N) de díades que pontuaram nos itens do SEAL no grupo caso p. 71

Tabela 2. Contagem $(\mathrm{N})$ de díades que pontuaram nos itens do SEAL no grupo caso na segunda subfaixa de idade.

p. 71

Tabela 3. Contagem $(\mathrm{N})$ de díades que pontuaram nos itens do SEAL no grupo controle. p. 72

Tabela 4. Contagem $(\mathrm{N})$ de díades que pontuaram nos itens do SEAL no grupo controle na segunda subfaixa de idade.

p. 72

Tabela 5. Quantidade do número de ausentes no SEAL entre os grupos caso e controle na primeira subfaixa de idade.

p. 73

Tabela 6.Quantidade do número de ausentes no SEAL entre os grupos caso e controle na segunda subfaixa de idade

p. 73

Tabela 7. Distribuição, na primeira subfaixa, de díades do grupo caso e controle com ou sem dificuldade no processo de aquisição de linguagem.

p. 74

Tabela 8. Distribuição, na segunda subfaixa, de díades do grupo caso e controle com ou sem dificuldade no processo de aquisição de linguagem. p. 75

Tabela 9. Distribuição, na primeira subfaixa, das díades Ñ-DD e DD avaliadas pelo IRDI em comparação com as díades Ñ-DL e DL avaliadas pelo SEAL p. 76 
Tabela 10. Distribuição, na segunda subfaixa, das díades Ñ-DD e DD avaliadas pelo IRDI em comparação com as díades Ñ-DL e com DL avaliadas pelo SEAL........... p. 77

Tabela 11. Distribuição, na primeira subfaixa, das díades SR e R avaliadas pela ADBB em comparação com as díades Ñ-DL e DL avaliadas pelo SEAL............................ p. 77

Tabela 12. Distribuição, na segunda subfaixa, das díades SR e R avaliadas pela ADBB em comparação com as díades Ñ-DL e DL avaliadas pelo SEAL........................... p. 78

Tabela 13. Associação de DL pelo SEAL nas diferentes subfaixas de idade. p. 78

Tabela 14. Variação de gênero masculino e feminino, nas duas subfaixas de idade, com o fator DL e N-DL no processo de aquisição de linguagem pelo SEAL p. 79

Tabela 15. Variação de categorias de escolaridade, nas duas subfaixas de idade, com o fator DL e Ñ-DL no processo de aquisição de linguagem pelo SEAL ...................... p. 80

Tabela 16.Regressão Logística sobre as variáveis sexo e escolaridade sobre DL pelo SEAL p. 81

Tabela 17. Análise DL e N-DL sem divisão das subfaixas de idade. p. 81 


\section{LISTA DE GRÁFICOS}

Gráfico 1. Distribuição de díades do grupo caso e controle com (DL) ou sem (Ñ-DL) dificuldade no processo de aquisição de linguagem............................................. p. 75

Gráfico 2. Distribuição de díades do grupo caso e controle com (DL) ou sem (N-DL) dificuldade no processo de aquisição de linguagem............................................. p. 76 
APRESENTAÇÃ

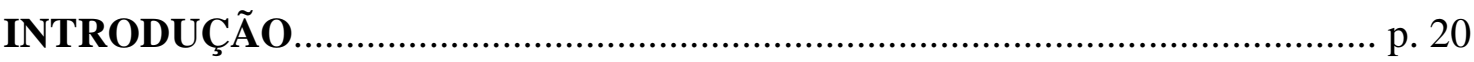

CAPÍTULO 1: COMUNICAÇÃO E AQUISIÇÃO DE LINGUAGEM............. p. 23

1.1 DESENVOLVIMENTO INFANTIL EM WINNICOTT ................... p. 23

1.2 COMUNICAÇÃO E AQUISIÇÃO DE LINGUAGEM PARA WINNICOTT ............................................................................. p. 30

1.3 O MANHÊS E A LINGUAGEM SOBRE OUTROS PRISMAS E ALGUMAS CONSONÂNCIAS COM WINNICOTT ....................... p. 30

1.3.1 Cena 1: Esther e Mariah (11 meses)...................................... p. 35

1.3.2 Cena 2: Sabrina e Ana (9 meses) ....................................... p. 36

1.3.3 Cena 3: Fabi e José (6 meses)............................................. p. 38

1.3.4 Cena 4: Carla e Bruna (4 meses)........................................ p. 40

CAPÍTULO 2: COMPORTAMENTO VOCAL NO TRANSTORNO DO ESPECTRO DO AUTISMO (TEA) ........................................................... 42

2.1 BREVES CONSIDERAÇÕES SOBRE O TEA................................ p. 42

2.2 COMPORTAMENTO VOCAL NAS CRIANÇAS COM TEA........ p. 44

2.3 UM GRUPO QUE MERECE ATENÇÃO: IRMÃOS....................... p. 48

CAPÍtULO 3: AQUISIÇÃO DE LINGUAGEM E EMBASAMENTOS DO SEAL ..p. 51

3.1 CONCEITO DE ENUNCIAÇÃO E OUTROS ASPECTOS DA LINGUAGEM.......................................................................... 51

3.2 VOZ E LINGUAGEM: CONSIDERAÇÕES A PARTIR DE OUTROS

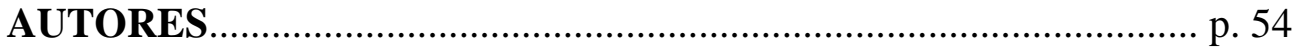

3.3 CAPÍTULO 4: PESQUISA EMPÍRICA........................................... p. 59

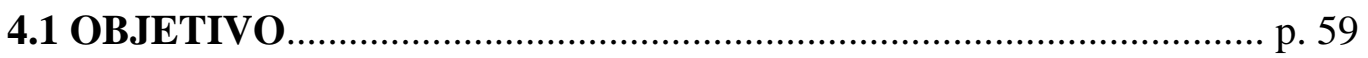

4.2 CARACTERIZAÇÃO DA PESQUISA …….................................... p. 59

4.3 SEUS PARTICIPANTES............................................................... 59

4.4 INSTRUMENTOS DE AVALIAÇÃO........................................... p. 60

4.4.1 Sinais Enunciativos na Aquisição de Linguagem (SEAL).... p. 60

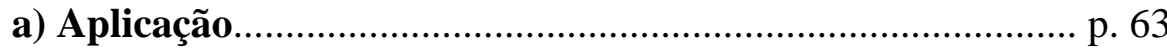

4.4.2 Indicadores de Risco ao Desenvolvimento Infantil (IRDI).. p. 64 
4.4.3 Escala de Retraimento Prolongado da Criança (ADBB AlarmDistress Baby Scale)........................................................ p. 66

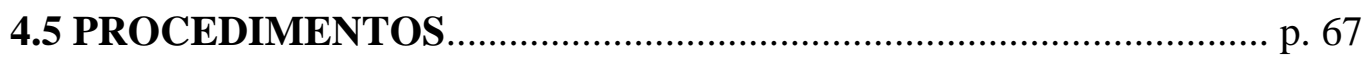

4.6 AVALIAÇÃO DAS FAMÍLIAS..................................................... p. 67

4.7 PREPARAÇÃO PARA ANÁLISE................................................... p. 69

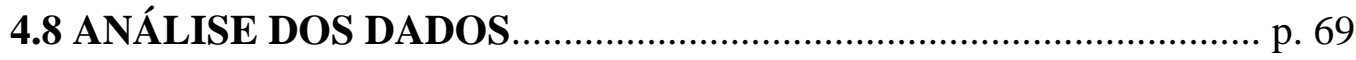

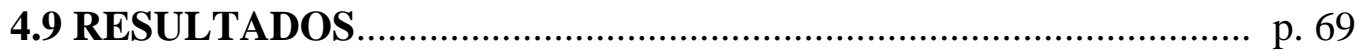

4.9.1 O SEAL nos grupos caso e controle................................ p. 70

a) Análise descritiva do SEAL ......................................... p. 70

b) Descritiva da soma do número de ausentes pelo SEAL..... p. 72

c) Associação qui-quadrado (Pearson) para dificuldade ou nãodificuldade de Linguagem.............................................. p. 74

4.9.2 O SEAL e instrumentos............................................... p. 76

a) IRDI E SEAL: Análise de Associação pelo Teste Exato de Fisher para Dificuldades de Desenvolvimento (DD) e DL.. p. 76

b) ADBB e SEAL: Análise de Associação pelo Teste Quiquadrado Pearson para Retraimento $(R)$ na ADBB e DL pelo SEAL p. 77

4.9.3 O SEAL e outros fatores p. 78

a) Fator Idade e DL pelo SEAL: Análise de Associação pelo Teste Qui-quadrado Pearson. p. 78

b) Sexo, escolaridade e DL para o SEAL: Análise de Associação pelo Teste Qui-quadrado Pearson......................................... p. 79

c) Teste de regressão logística sobre os fatores...................... p. 80

4.9.4 O SEAL sem a divisão de subfaixas de idade.................... p. 81

4.10 DISCUSSÃO

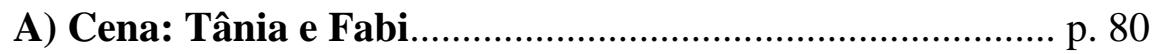

CAPÍTULO 5: CONSIDERAÇÕES FINAIS ............................................... p. 95

REFERÊNCIAS BIBLIOGRÁFICAS ................................................... p. 98 


\section{APRESENTAÇÃO}

Minha trajetória está marcada pelo trabalho com bebês e crianças pequenas, tanto como aprimoranda da AACD (Associação de Assistência à Criança Deficiente), como no Núcleo PaisBebês do Setor de Saúde Mental da Universidade Federal de São Paulo, no qual atuei por três anos, inicialmente como especializanda e posteriormente como colaboradora, além de participação por três anos no Grupo de Estudos de Observação de Bebês pelo Método Ester Bick em consultório particular. Tais lugares me levaram a entrar em contato com uma gama de crianças com possíveis diagnósticos de TEA (Transtorno do Espectro Autista) que apresentavam dificuldades nas competências sociais e comunicacionais, despertando em mim um desejo de aprofundar meus estudos e conhecimentos sobre o tema.

Este trabalho de mestrado partiu inicialmente da pesquisa: "Vulnerabilidade de pais e irmãos de crianças com transtorno do espectro autista" (financiada pela FAPESP com o processo número 13/25332-6 e pela Associação Internacional de Psicanálise com o processo número 1740613), com coordenação do Prof. Dr. Rogério Lerner (PSA - IPUSP), tendo como pesquisadora responsável a Dra. Julia Durand. Iniciei neste grupo no ano de 2014 como bolsista de treinamento técnico trabalhando na avaliação dos bebês participantes. Desde 2013, pesquisadoras bolsistas, mestrandas, doutorandas e pós-doutoranda auxiliaram na avaliação de famílias e continuam desenvolvendo projetos de pesquisas que investigam aspectos da saúde mental de mães de filhos com Transtorno do Espectro Autista, bem como desenvolvimento de bebês, seus irmãos mais novos, qualidade das interações mãe-bebê, além da avaliação de modelo-piloto de intervenção em díades consideradas em risco pela literatura.

O grupo objetivou trabalhar em conjunto na análise dos dados coletados, construindo um perfil de 144 famílias no total com um filho (a) mais velho diagnosticado com TEA (Transtorno do Espetro Autista) e que possuem outro filho (a) entre 2 e 24 meses em comparação com famílias que possuem um filho mais velho sem este diagnóstico, tendo como intuito o desenvolvimento de novos conhecimentos que promovam melhores condições de saúde psíquica para todos, sem deixar de olhar para as especificidades de cada criança, pai, mãe, cuidador e também profissional da rede pública de saúde

Crianças do grupo que possuía um irmão mais velho com TEA verbalizaram mais do que crianças do grupo com um irmão mais velho sem tal diagnóstico, avaliadas a partir da CIB, Coding 
Interactive Behavior (Feldman, 1998) e ADBB, Alarm Distress Baby Scale (Guedeney \& Fermanian, 2001), contrariando aquilo que a literatura e a clínica apontam a este respeito, na qual bebês irmãos de crianças com autismo apresentam maiores dificuldades para iniciar uma interação, buscar contato por meio visual, responder ao chamado e imitar (Newschaffer et al, 2012; Rogers, 2009). Hipotetizou-se que pode ser esta uma particularidade da amostra ou que os instrumentos utilizados não foram suficientemente sensíveis para captar uma suposta variação entre os grupos em relação a este aspecto em específico, já que é esperado que a verbalização ocorra com maior frequência no grupo de bebês com irmãos sem o diagnóstico de TEA.

A partir desta inquietação, caminhei por tentar compreender e igualmente encontrar algum instrumento capaz de captar de maneira mais específica os aspectos ligados ao processo de aquisição de linguagem, no qual a verbalização também faria parte. A CIB e a ADBB não possuem nenhum propósito de indicar questões de aquisição de linguagem, porém o resultado obtido com a CIB fez com que meu interesse por esta questão emergisse, pensando igualmente na aquisição de linguagem como um dos pilares que compõe desenvolvimento global infantil e sua importância para a construção subjetiva do bebê.

É importante ressaltar que partimos do pressuposto de que verbalização é um dos aspectos da linguagem, sendo o resultado obtido com a CIB um disparador para expandir meus interesses relativos ao universo linguístico e à aquisição de linguagem. Cabe também destacar que o funcionamento da língua é sempre multimodal, com mesclas de ações gesto-vocais; McNeill (1985) propõe que gesto e fala se encontram integrados numa mesma matriz de produção e significação e são constitutivos de um único sistema linguístico.

A partir daí, realizei uma busca ativa na literatura cientifica a fim de me apropriar mais de conceitos de linguagem e instrumentos capazes de avaliar tal aspecto. Dentro deste panorama encontrei o SEAL - Sinais Enunciativos de Aquisição de Linguagem; já validado para crianças de até 12 meses e que continua em processo de estudo por pesquisadores da área de Fonoaudiologia e Psicologia da Universidade Federal de Santa Maria, liderados pela Prof. Dra. Ana Paula Ramos de Souza. Tal instrumento propõe-se a detectar possíveis sinais de dificuldades no processo de aquisição de linguagem em bebês e crianças pequenas a partir de uma visão enunciativa de aquisição de linguagem, que será explicada mais adiante.

Com o instrumento encontrado, iniciei um diálogo com a Prof. Ana Paula Ramos, que auxiliou e aprimorou minha compreensão do SEAL, oferecendo caminhos para que eu refletisse 
melhor sobre a teoria enunciativa do linguista Benveniste, teórico motivador da construção do SEAL, e alguns dos processos intrincados sobre esta. Foram realizados encontros pessoalmente na cidade de São Paulo, assim como alguns por videoconferência.

Apresento aqui o resultado desta caminhada de estudos e aprofundamentos de experiências que partiram de minha prática clínica e se revelam nesta dissertação. 


\section{INTRODUÇÃO}

O projeto maior do qual esta dissertação se deriva surgiu após diversos autores (Cassel $e t$ al., 2007.; Baker-Ericzen, Brookman-Frazee \& Stahmer, 2005; Crespin, 2004; Elsabbagh, M et al., 2012; Hastings et al., 2005; Hoffman et al., 2009; Kasari \& Sigman, 1997; Ozonoff et al., 2011; Montes \& Halterman, 2007 e Slade, 2009) indicarem que bebês irmãos de crianças com TEA são mais vulneráveis a diversos problemas do desenvolvimento (10 a 20\%) assim como os pais dessas crianças estão mais suscetíveis a sintomas depressivos, de estresse e ansiedade (Marques \& Dixe, 2011; Osborne \& Reed, 2010.

A pesquisa da qual esta dissertação se origina obteve seus principais resultados nas díades com bebês até 12 meses pelo instrumento CIB - Coding Interactive Behavior (Feldman, 1998), onde irmãos de crianças com autismo tiveram médias maiores em retraimento $(\mathrm{p}=0,003)$ e maior prevalência de sinais de dificuldades de desenvolvimento $(\mathrm{p}=0,055)$ quando comparados com bebês irmãos de crianças sem TEA. Além disto, as mães das famílias de crianças com autismo apresentaram médias maiores de humor depressivo $(p=0,008)$ e constrição nas interações $(p=0,024)$ avaliados também pela CIB, quando comparadas com mães de bebês sem autismo. Para as crianças de 12 a 26 meses de idade, observou-se que as mães de crianças com autismo apresentaram médias maiores de intrusividade quando comparadas com as de crianças sem autismo (Durand et al., Infant Mental Health Journal, no prelo).

A partir deste ponto de partida, esta dissertação de mestrado tem como objetivo principal estudar a possível presença de sinais de atraso na aquisição de linguagem entre díades compostas por mães de uma criança com autismo e seu filho mais novo (grupo caso) em comparação às mães de crianças sem autismo e seu filho mais novo (grupo controle). O trabalho partiu dos dados de crianças com até 12 meses e 29 dias coletados do banco da pesquisa mais ampla que the antecede, expandindo seus resultados para a questão central estudada aqui, referente ao processo de aquisição de linguagem.

Sabemos que a voz nas interações sonoras entre mães e seus bebês pode ser vista como função integrativa do self e abordada como porta de entrada para a relação entre o eu e o tu, representando uma forma de vínculo que inicia contornos pulsionais antes que o olhar ou o significado apareçam. Malloch \& Trevarthen (2009) relatam sobre o momento de júbilo do bebê ao estabelecer uma protoconversação em contato afetivo com seus pais. O recém-nascido é envolvido em uma complexa rede de desejos e interdições que compõe o ambiente no qual ele é recebido. 
Quando a comunicação mãe-bebê se encontra com problemas, ao se pensar na reciprocidade queste vínculo impõe, entremeada de ritmo, sincronia e ajuste mútuo, faz-se necessário um olhar direcionado e cabíveis intervenções para que não haja prejuízos fundantes e cristalizações de sintomas.

Esta dissertação tem a intenção de refletir brevemente sobre o universo deste tema em consonância com a teoria de desenvolvimento emocional do psicanalista D. W. Winnicott e os conceitos de holding e handling, além de outros autores e algumas fundamentações da perspectiva enunciativa, que afirma que o falante, tomado aqui na relação mãe-bebê, se inscreve na linguagem pela construção dialógica do eu e do tu, delimitando um espaço de presença e ausência. “(...) Enunciar é assumir o lugar do eu no diálogo, para, em seguida, abandona-lo em favor do tu, para que este assuma também o lugar de eu” (Oliveira \& Ramos-Souza, 2014, p. 1701). O SEAL Sinais Enunciativos de Aquisição de Linguagem está ancorado na teoria enunciativa explorada por Silva (2007), que traz a concepção de linguagem desenvolvida por Benveniste, segundo a qual a aquisição de linguagem não pode ser compreendida apenas em um quadro de sistema linguístico predeterminado, mas como processo que envolve o jogo dialógico e a construção conjunta de significações, abrindo espaço para interpretar as possíveis faltas como fato integrante do processo de construção da linguagem em uma perspectiva intersubjetiva, própria de um indivíduo que é singular (Crestani, 2016).

Delineando os caminhos desta pesquisa, partiremos do desenvolvimento emocional do bebê pelo olhar de Winnicott, seguindo para os aspectos comunicacionais e de aquisição de linguagem, a fim de contextualizarmos melhor nosso universo de estudo, ilustrando-o com 4 vinhetas clínicas. Posteriormente passaremos pela questão do Transtorno do Espectro do Autismo (TEA) e os aspectos comunicacionais intrincados nele, chegando finalmente à problemática dos irmãos, na qual este trabalho se foca. Por fim apresentaremos de forma breve alguns pontos relativos à aquisição de linguagem que embasam o instrumento escolhido e outros achados sobre o universo da linguagem a partir de autores que trataram do tema.

Das 144 díades mães bebês, apresentaremos os achados estatísticos de 80 delas, a partir do recorte de idade de crianças de até 12 meses e 29 dias, idade corte utilizada pelo SEAL, além dos resultados de outros instrumentos utilizados na pesquisa maior, discutindo posteriormente tais efeitos e analisando as questões acerca dos sinais no processo de aquisição de linguagem a fim de tecermos considerações acerca da nossa problemática. Além disto, apresentarei uma vinheta clínica 
de uma dupla mãe-bebê escolhida dentro do universo amostral a fim de ilustrar os resultados empíricos e nos aproximar de nossa problemática por outro olhar. 


\title{
CAPÍTULO 1: COMUNICAÇÃO E AQUISIÇÃO DE LINGUAGEM
}

\subsection{DESENVOLVIMENTO INFANTIL EM WINNICOTT}

\author{
“(...) um olhar infantil primitivo, diferente daquele da mãe ou \\ do observador externo e que esse olhar infantil \\ seja examinado de forma "proveitosa" \\ (Winnicott, 1975 p. 96, tradução nossa).
}

Este trecho de Winnicott revela a necessidade de se olhar para o bebê a partir de sua própria perspectiva, com uma postura sensível frente aquilo que se mostra para ele, diferenciando-o da experiência do adulto. Mesmo com este olhar que visa a existência da singularidade da criança é importante salientar que se parte do paradoxo mãe-bebê para afirmar a possibilidade da existência do bebê.

Winnicott concebe o desenvolvimento como potencialidade de ser, não sendo algo inato. Para que tal desenvolvimento ocorra é necessário o encontro de um ambiente suficientemente bom e adaptado às necessidades do bebê, a fim de que os estágios maturacionais se fundamentem. As fases iniciais serão os alicerces da personalidade e da saúde psíquica do indivíduo e, para o autor, qualquer estágio no desenvolvimento nunca deixa de ter certa importância, apesar de gradativamente perder sua essência vital. Os estágios são alcançados e perdidos, sucessivamente, até sua transformação em fato, que ocorre em ritmo gradual ao longo da vida, dentro de determinadas condições ambientais. Ainda de acordo com Winnicott (1990, p. 55) “(...) é necessário que se presuma um desenvolvimento anterior bem-sucedido. O mais complexo deve desenvolver-se a partir do mais simples".

As tarefas não deixam de existir mesmo quando não há o alcance de determinado requisito, podendo haver um estacionamento no estágio maturacional, causando distúrbios emocionais. O indivíduo por falta de maturidade apoia-se em bases falsas para resolver as tarefas impostas, impossibilitando uma aquisição pessoal consistente do si-mesmo.

Os três momentos de desenvolvimento emocional descritos por Winnicott consistem em dependência absoluta, dependência relativa e rumo à independência. 
Para Winnicott (1990) desde a vida intrauterina o bebê é considerado um ser humano, pois já existe a capacidade de memória destas experiências vividas, ainda que o bebê se encontre em extrema dependência do ambiente para que haja a construção de significados destas vivencias. A primeira experiência é a da dependência absoluta, onde a distinção do $e u$ e não-eu ainda se mostra pouco evoluída e a mãe encontra-se em um estado psicológico que Winnicott denominou como preocupação materna primária, termo que designa a condição materna de abdicação de seu narcisismo para se identificar com seu filho e se colocar enquanto instrumento facilitador. Esta condição se desenvolve no final da gestação e nas primeiras semanas ou meses após o parto, permitindo à mãe estabelecer uma experiência de mutualidade que propicia uma ativa adaptação às demandas de seu filho. O cuidado do tipo paterno também é desenvolvido e representa o apoio à mãe/cuidadora a fim de que ela possa se dedicar integralmente às necessidades do bebê.

O bebê é visto por Winnicott como um ser complexo que inclui seu potencial e o meio ambiente no qual está inserido. Este ambiente é formado pela mãe, outros cuidadores e ambiente físico. A vivencia de experimentações neste ambiente permitirá a integração psique-soma e a formação do self, sendo o espaço fundante do vir a ser humano.

De acordo com Fulgêncio (2008) há um paradigma proposto por Winnicott do bebê no colo de sua mãe, compreendido enquanto relação unitária para o bebê e dual para a mãe. O que existe é um par lactante-lactente, no qual a existência do bebê está intrinsicamente ligada à figura materna. “(...) se olharmos através dos olhos do bebê, veremos que ainda não há um lugar a partir do qual olhar. No entanto, a semente de todo o desenvolvimento futuro está ali, e a continuidade da experiência do ser é essencial para a saúde futura do bebê que virá a ser um indivíduo" (Winnicott, 1990, p. 153).

Neste estágio de dependência absoluta, tudo é novo para o bebê, não existindo qualquer medida para julgamento ou comparação, havendo uma experiência de ilusão de que nada existe para além de si mesmo. Esta ilusão criativa, de que tudo foi criado por ele, traz a sensação de onipotência do bebê, capaz de lhe oferecer segurança e formas de lidar com o mundo que ele minuciosamente se depara (Winnicott, 1975).

Tal ilusão tem início com a experiência da primeira mamada, onde "o bebê está pronto para criar, e a mãe torna possível para o bebê ter a ilusão de que o seio, e aquilo que o seio significa, foram criados pelo impulso originado na necessidade" (Winnicott, 1990, p. 121). As repetidas experiências de criação do bebê com o oferecimento do seio pela mãe lhe desenvolvem a ilusão e, 
desta forma, o contato entre a psique e o ambiente (Winnicott, 1982). O objeto subjetivo cria-se desta forma, na medida em que o bebê crê que fez o seio existir a partir de sua necessidade. De acordo com Safra (2005, p. 20) este objeto dá início à constituição do self pela criança, sendo possível a percepção da realidade objetiva. A ilusão tem um papel de extrema importância no processo maturacional, pois é através dela que o bebê realizará a transição entre realidade subjetiva e objetiva, integrando novas possibilidades de existir a partir de sua criatividade.

O existir de um ambiente constante, onde a mãe é capaz de oferecer o seio ao bebê no momento da necessidade, cria um estado de confiança no bebê, desenvolvendo-se um espaço potencial, que será posteriormente desenvolvido.

Até próximo dos 6 meses de vida o bebê desconhece o estado de dependência, possuindo uma ilusão onipotente de conceber sua existência distinta do mundo externo. Porém, é a partir da desilusão desta indistinção entre mãe e bebê que se desenvolvem habilidades mentais, que culminam no processo de diferenciação entre ambos, já que o infante adquire consciência da necessidade de atrelamento para com a mãe, o que se dá no período de dependência relativa.

No estágio maturacional da dependência relativa há uma diferenciação do eu e do não-eu. A criança passa a ter consciência do próprio corpo, é capaz de usar a ambivalência e espera-se o surgimento do sentimento de culpa e preocupação.

O sentimento de onipotência passa a ser relativo, já que a figura materna vai aos poucos retornando às suas atividades e compromissos, o que implica no bebê a adaptação a esta nova realidade, que está fora do seu controle. Winnicott (1983) afirma que o bebê nesta fase passa a tolerar mais frustações, iniciando também a compreensão intelectual.

O existir de um ambiente constante e regular promove confiança, permitindo a criança antecipar acontecimentos e ir construindo a percepção de uma realidade independente dela. E, assim, se inicia a "humanização" do bebê, que auxiliada pelas experiências relativas aos fenômenos transicionais, permitirá ao bebê lidar com as ansiedades de perda e separação, e que o pensar e o fantasiar surjam (Winnicott, 2000). Quando o bebê não pode contar com "uma pessoa para juntar seus pedaços, ele começa com uma desvantagem na tarefa de integração do si mesmo e talvez não consiga empreendê-la, ou não consiga manter sua integração com confiança" (Winnicott, 2000, p. 276).

Ocorre igualmente o desenvolvimento do corpo do bebê, que passa a ser capaz de interagir com os objetos, manipula-los, iniciando um jogo simbólico com o outro. As aquisições motoras 
ampliam o universo do bebê, fazendo igualmente com que ele seja mais independente dos cuidados maternos, ampliando o contato com os objetos e auxiliando-o a diferenciar o eu e o não-eu.

Há no estágio de dependência relativa o que chamamos de personalização, mecanismo de integração entre o self e o soma ${ }^{l}$ capaz de distinguir o eu e o não-eu e personalizar a existência do ser.

Neste momento é exigido da mãe outro manejo para que consiga satisfazer as necessidades de seu filho, não tão mais focadas no holding, mas no handling.

É papel materno a promoção de um ambiente sustentador, “suficientemente bom”, que promova este amadurecimento do bebê; dentro deste contexto o holding, handling e a apresentação de objetos tem funções primordiais. O primeiro refere-se à capacidade materna/cuidador de oferecer sustentação e suporte ao infante, tendo como princípio básico o processo de identificação. Se define enquanto experiência física e simbólica, na medida em que tal vivência promove a confiança de ser amado e desejado. O acolhimento seguro e necessário oferecido ao bebê, descrito pelo autor como uma extensão da "capacidade fisiológica que caracteriza o período pré-natal" (1960, p.49) e igualmente realizado de forma constante, promove a estruturação da capacidade da criança em sentir-se real. A relação de holding assume importante função na integração do self, se estabelecendo como sustentação física e emocional dentro da relação mãe bebê, na medida em que esta mãe se apresenta enquanto espelho.

Winnicott, no artigo "O papel de espelho da mãe e da família no desenvolvimento infantil" (1975), propõe a noção de espelho como rosto humano, no caso, o rosto materno, trazendo a ideia da compreensão de um reconhecimento verdadeiro, autentico, expresso através deste rosto da mãe, que se adaptaria às necessidades do bebê. Neste modelo o indivíduo se distingue a partir da presença real, viva, que se estabelece na relação com o outro e não parte da virtualidade e de aspectos imagéticos no reconhecimento de si. Além disto, a função especular não estaria a serviço do Eu, mas à integração do self, referindo-se a um momento mais primitivo do desenvolvimento humano, anterior à organização de uma representação do Eu.

“O holding inclui especialmente o holding físico do lactente, que é uma forma de amar. É possivelmente a única forma em que uma mãe pode demonstrar ao lactente o seu amor"

\footnotetext{
1 "O que é elaborado psiquicamente não é a máquina fisiológica, mas precisamente esse corpo vivo, capaz de se mover, entrar em repouso, respirar, ficar tenso, mamar, digerir, evacuar, ter coordenação motora, tônus muscular, ficar excitado, ereto, andar e assim por diante. O soma Winnicottiano não é corpo físico, é corpo vivo personalizado, de modo que tudo o que Winnicott tem a dizer sobre ele cabe o título "resultados da elaboração imaginativa". (Loparic, 2000 p.364).
} 
(Winnicott, 1983, p. 48). No estágio de dependência absoluta, a mãe, se adequando às necessidades do bebê, confirma a onipotência da criança, atendendo às suas necessidades conforme a demanda.

Além do afeto físico, a comunicação entre mãe e bebê se faz de grande importância neste processo, onde a mãe, se aproximando da experiência do filho, encontra formas de dialogar com ele, em uma sintonia comunicacional. O chamado manhês, prosódia peculiar de um adulto ao se dirigir à criança, será melhor desenvolvido neste trabalho, trazido também sobre o olhar de outros autores.

A comunicação não verbal, citada por Winnicott tal como movimento de respiração, sons do batimento cardíaco da mãe, movimentos do contato físico entre mãe e bebê nos diferentes estados emocionais maternos se faz igualmente importantes para o bebê neste processo de confiança de um meio ambiente seguro.

Percebe-se o quanto a questão do cuidado está presente na função especular winnicottiana, trazido aqui não só nos aspectos do holding, pelo acolhimento de gestos espontâneos do bebê e um olhar sensível e atento, mas também pelos aspectos do handling, promotor também de experiência de integração e pertencimento do bebê em seu ambiente. Este último é caracterizado tanto pelos cuidados que a mãe oferece ao bebê voltados às suas necessidades fisiológicas e ao seu corpo, como também através de comportamentos sociais parentais, como falar, cantar, ninar, fazer careta, entre outros. O handling tem enquanto objetivo estabilizar as necessidades corporais/orgânicas e emocionais da criança, a partir da construção de uma confiabilidade no ambiente externo, que, juntamente com o holding vão constituir o processo de integração e personalização infantil. "Segurar e manipular (hold e handle) bem uma criança facilita o processo de maturação, e segurála mal significa uma incessante interrupção desses processos, devido às reações do bebê às quebras de adaptação" (Winnicott, 2006, p. 54).

Por último e não menos importante, a apresentação de objetos se insere no campo na subjetivação como um instrumento que capacita a criança a ser um agente ativo na resolução de suas necessidades frente ao mundo, em uma ação que circula pela criatividade. Para que esta ação criadora surja é necessária a apresentação simplificada e rotineira de objetos ao bebê que se conformam, acima de tudo, com a capacidade de dispor destes artifícios com os próprios recursos corporais. Para tal, tais objetos necessitam de qualidades que não coloquem em risco a regularidade e a continuidade do ambiente, além de servirem enquanto instrumentos para que o infante recupere a familiaridade com este mundo. 
É na apresentação simplificada e rotineira destes elementos que o bebê constrói sua confiança, sendo que a mãe, em seu estado de preocupação materna primária, é a primeira e principal representante do espaço e, a forma como ela se apresenta a seu filho, mesclada por variâncias temporais (presença e ausência) se mostra enquanto peça essencial no processo do vir a ser do indivíduo.

Porém, Winnicott refere problemas quando a mãe se afasta por um período maior do que o tolerável para a criança, já que a capacidade do bebê de preservar sua experiência de onipotência e seu impulso agressivo-criativo sobre o mundo está atrelado a aspectos temporais. A ausência materna pode provocar um estremecimento da confiança do bebê nesta fonte real de satisfação representada pela mãe e a continuidade da experiência pessoal de ser pode ser interrompida. Por tais necessidades o autor afirma que a variação temporal da presença materna se faz tão imprescindível quanto suas qualidades sensíveis. A capacidade do bebê de suportar a ausência precisa estar atrelada à competência do bebê de aguentar estar só, caminho que se constrói no espaço de confiança de um ambiente a partir da apresentação de objetos em pequenas doses e na capacidade suportiva do handling e holding. A qualidade afetiva destas interações, interpostas por um olhar sensível e amoroso através de jogos e brincadeiras, reforça a relação de confiança entre o bebê e seu mundo, compreendendo que a identificação emocional entre mãe e criança se configura como central no curso de integração infantil, que culmina com autonomia e independência do bebê.

No estágio maturacional rumo à independência, a partir dos dois anos de idade, a criança reconhece a existência do pai enquanto separado de si e diferente da mãe, mantendo uma relação triangular com estas figuras, porém ainda necessita ser amparada e estar em um ambiente estável, na qual a segurança e o cuidado se fazem importantes. Winnicott não se opõe ao complexo de Édipo e compreende a formação edípica na criança a partir de um processo no qual o uso de objetos está incluso e o infante já consegue sustentar uma relação triangular.

Dentro deste ambiente seguro, o bebê se torna capaz de assumir as responsabilidades de seu impulso instintivo, no qual a raiva se transforma em preocupação e culpa, permitindo à criança experimentar o complexo edípico e suportar as ambivalências das novas configurações relacionais. Isto só é possível a partir da confiança do infante sobre a possibilidade de sua mãe sobreviver aos ataques e aceitar seus gestos reparadores. A partir daí as exigências intelectuais tomam conta da vida infantil, exigindo dela comportamentos sociais e afetivos, já que na fase rumo à independência a criança já é emocionalmente capaz de perceber a si mesma e os outros como 
pessoas totais, além de realizar brincadeiras e entrar no sonho do adulto. As angústias e ansiedades evocadas nas relações são agora mais controladas, sendo que a noção de que a passagem do tempo proporciona alívio de sentimentos ruins, como dores, desespero e mágoas também pode ser conquistada (Winnicott, 1990).

Neste estágio, a criança é capaz de vivenciar a realidade dentro da distinção da objetividade e subjetividade. A realidade objetiva freia a fantasia total e torna suportável a realidade, apresentada pela mãe a partir da exposição dos objetos e da vivencia da experiência de ilusão. No processo de capacitação da criança para usar os objetos e explicitar melhor as relações objetais, Safra (2002) nos diz:

Winnicott tratou dessa questão de maneira brilhante, ao abordar o que denominou "Uso de um objeto". Ele assinala que a passagem de relacionar-se com o objeto para usar o objeto assenta-se sobre a capacidade do sujeito de destruir o objeto, para, desta forma, tirá-lo da área de seu controle onipotente. Segundo ele, isto é parte do caminho para o estabelecimento do princípio de realidade. Eu diria que é mais do que isso. Trata-se do momento em que a pessoa entra na possibilidade de não só criar o mundo, como fez no estado subjetivo, mas de criar no mundo, pois o indivíduo entra, por esse meio, no mundo.

O alojamento do self no mundo prossegue em movimentos cada vez mais sofisticados. Eventualmente, o indivíduo terá uma história que poderá ser narrada e datada (...) (Safra, 2002, p. 24, 25).

Para Winncott, o desenvolvimento humano é um processo que se desenvolve até o momento da morte, e ao longo deste caminho de busca de integridade do ser, o deparar-se com a precariedade se faz constante, mesmo após a instalação do si-mesmo, que se desenvolve com o nascimento da subjetividade da criança. A adolescência e a vida adulta são também importantes períodos pelos quais o indivíduo deverá passar, cabendo importantes alterações do trajeto da vida, que está em constante construção.

Partimos destes pressupostos ao olharmos para os bebês e suas mães que compõe este trabalho, sendo importante contextualizar de onde parte nossa visão sobre as díades estudadas para, a partir daí, introduzirmos os aspectos ligados à aquisição de linguagem. 


\subsection{COMUNICAÇÃO E AQUISIÇÃO DE LINGUAGEM PARA WINNICOTT}

Quando a mãe é capaz de se adaptar às necessidades do bebê, oferecendo segurança para que ele confie e acredite na realidade externa, há, como já argumentado, a saída do estado de onipotência do bebê, propiciando uma nova etapa de apropriação da criança no uso de objetos. Este estágio firma a entrada no simbólico e, portando, abre espaço para o uso da linguagem.

Vale ressaltar que bebês e adultos expressam uma cooperação psíquica que pode ser observada desde os primeiros momentos da vida do infante, como afirmam Araújo e Lerner (2010). E que o bebê apresenta "uma predisposição para rudimentos de capacidades sociais que permitem uma harmonização afetiva e a regulação emocional, gerando uma sensação de estabilidade interna e levando a uma comunicação precoce entre a criança e seu cuidador” (Araújo e Lerner, 2010, p. 36).

Winnicott afirma que a comunicação da mãe com seu bebê está alicerçada sobretudo na mutualidade estabelecida entre os locutores, indo além das necessidades fisiológicas satisfeitas, como indica o trecho:

Os bebês se alimentam e isto pode significar muito para a mãe, e a ingestão de comida concede ao bebê gratificação em termos de satisfações pulsionais. Uma outra coisa, contudo, é a comunicação ente o bebê e a mãe, algo que é uma questão de experiência e que depende da mutualidade que resulta das identificações cruzadas. (Winnicott, 1994, p. 198).

Dentre o amplo universo da comunicação não verbal, Winnicott, ao trazer os conceitos de handling e holding, discorre sobre o diálogo tônico-postural, acompanhado de manifestações verbais da mãe. Os movimentos de respiração, batimentos cardíacos, calor do seio e estados emocionais maternos também oferecem espaço para que o bebê se aproprie do ambiente e se desenvolva.

A capacidade de simbolização do bebê, descrita pelo autor pela via do brincar, acaba igualmente por ser levada em consideração ao tentarmos apreender a questão da linguagem na obra de Winnicott. O uso de objetos (frisa-se aqui a necessidade de o objeto ser real, no sentido de fazer parte da realidade compartilhada ente mãe e bebê) e a capacidade que o indivíduo tem de destruir este objeto, tira-o de seu lugar onipotente. Neste momento, a destruição desempenha um importante papel na construção da realidade, colocando o objeto fora do self, em um movimento de descoberta da própria externalidade. 
É neste espaço potencial, espaço do brincar, área da criatividade entre indivíduo e o meio ambiente, que o bebê experimenta o viver criativo, unindo e separando-se de sua mãe, em um movimento de construção de confiança. Se apropriar da realidade é entrar no mundo da linguagem.

Winnicott, em seus escritos, não se ateve a uma teoria linguística, focando em formas de comunicação não verbais e pré-verbais emergentes na relação com o bebê e sua mãe, refletindo sobre a linguagem enquanto mutualidade da experiência (Winnicott, 1994). Suas ações terapêuticas são focadas em experiências corporais, que retornam aos momentos de dependência tomados por outras questões distintas da linguagem verbal.

Este seu olhar o coloca como um grande percursor da psicanálise da primeiríssima infância e o traz como um autor essencial ao se refletir sobre o universo infantil. A fim de compreendermos mais sobre o âmbito da linguagem traremos agora visões da escola psicanalítica francesa, na qual esta questão foi amplamente aprofundada. A autora Marie Christine Laznik traz importantes contribuições aos refletirmos sobre interações sonoras entre mães e bebês e o estado destas mesmas interações em crianças com TEA.

\subsection{O MANHÊS E A LiNgUAGEM SOBRe OUTROS PRISMAS E AlgumaS CONSONÂNCIAS COM WINNICOTT}

Seguindo o caminho analítico de Freud e da escola francesa, há um processo de instalação do circuito pulsional pelo bebê, no qual a pulsão ${ }^{2}$ tem o propósito de cumprir sua meta de satisfação por meio do circuito de três tempos. No primeiro tempo há um movimento de busca pelo objeto oral por parte do bebê, Freud denominou esta etapa de busca ativa da parte do bebê (Laznik, 2004). No segundo tempo há o que Freud chama do retorno da pulsão sobre uma parte do próprio corpo do infante, em um movimento autoerótico ou reflexivo. E finalmente o terceiro tempo, identificado enquanto passivo por Freud, há a intenção de se fazer objeto para um outro.

2 Para Freud (2010), de forma bem superficial, pulsão (trieb) é um processo dinâmico, que impulsiona o organismo em direção a meta, o equilíbrio dos estados de tensão. Conceito entre o psíquico e o somático, se referindo à representação do somático no psiquismo. Para Lacan, pulsão não se refere à necessidade, nem ao registro orgânico, semelhante a Freud, refere-se ao limite entre o simbólico e o real, sendo representada no inconsciente pelos significantes, que indicam a demanda do sujeito ao Outro. 
Laznik afirma que neste momento há uma passividade ativa, já que o bebê procura se fazer olhar e ouvir pela mãe/cuidador, oferecendo o pé para "ser comido", por exemplo. No tempo de fechamento do circuito, que se repete e se reinventa inúmeras vezes na relação mãe-bebê, há a prova da existência de um outro para o bebê e, por consequência, o existir da pulsão. A entrada do desejo, dentro do processo de trocas intersubjetivas entre a díade encerra o terceiro tempo, que necessita de uma participação recíproca entre pais e bebê para que tal desenvolvimento ocorra.

Dentro deste universo das pulsões, destaca-se aqui a pulsão invocante, descrita por Lacan (1964), onde tomamos a voz enquanto objeto desta pulsão, na medida em que o se fazer ver e ter um outro que escuta se mostram importantes quando trata-se do tema em questão. Palladino (2007) afirma que, além da existência de um aparato biológico de fala, é necessário um modelo de aprendizagem advindo com a estimulação parental e, se existirem falhas, haverá problemas no desenvolvimento infantil e no processo de aquisição de linguagem.

A fala materna, o manhês, compreende toda emissão vocal materna ou de qualquer cuidador dirigida ao bebê, composta de uma prosódia peculiar. Apesar das distinções de comunicação sonora de cada mãe, existem certos elementos comuns, como a estrutura e sintaxe simplificada; expressões curtas; repetições rítmicas; sons desprovidos de significados e picos prosódicos acentuados. A integração destes é um fenômeno presente em muitas culturas, que encontra ecos sobretudo em situações amorosas (Socha, 2008).

Para Laznik, o manhês: “(...) descreve um conjunto particular de modificações no modo de falar de um adulto que se dirige a um bebê e que consegue captar sua atenção" (Laznik, 2004, p.15). A autora afirma que o poder da voz já está em ação mesmo antes do nascimento da criança e que a voz acaba por comandar o olhar e não o inverso, como costumeiramente imagina-se.

Através do trabalho com vídeos caseiros filmados por familiares de bebês que se tornaram autistas, ela percebeu que mesmo os bebês que se recusam a responder aos apelos e não olham espontaneamente nenhum adulto, não deixam de olhar as invocações de uma voz portadora de uma prosódia particular, descrita pelos psicolinguistas como característica do manhês. Em pesquisa realizada verificou-se que a voz gravada, na qual a mãe é incapaz de olhar para o bebê presente fisicamente (em oposição à uma imagem), impossibilita a genitora/cuidadora de produzir a prosódia característica, postada em entonação mais exagerada, com formações melódicas doces, longas e com extensões, essenciais para a captação do bebê (Laznik, Maestro \& Muratori, 2005). 
Laznik, Maestro \& Muratori (2005) compararam vozes de mães de crianças típicas e com TEA a partir de um aparelho realizador de análise espectral da voz e, confrontados os espectrogramas, observaram que a voz da mãe da criança com autismo não apresentava as características prosódicas do manhês em comparação à voz mais entoada da mãe da criança sem TEA. O desdobramento da pesquisa evidenciou que a não responsividade da criança com autismo afeta e impacta diretamente no manhês dos pais. Um estudo comparativo entre pais de crianças com desenvolvimento típico, pais de crianças com Síndrome de Down e outros de crianças com TEA indicou maior nível de estresse pelos pais de crianças com TEA, se comparados com os pais das crianças com desenvolvimento típico e com Síndrome de Down (Hayes \& Watdon, 2013).

O manhês e suas propriedades descritas revelam uma dimensão primordial da relação mãebebê, caracterizada como um gesto adaptativo e espontâneo da mãe ao infante, que permite com que esta criança reconheça seus próprios gestos sonoros ainda não articulados. Esta aproximação com a fala infantil propicia, a partir do próprio gesto espontâneo do balbuciar, a futura aquisição da linguagem pelo recém-nascido: "no seu balbuciar, o bebê imita o que ele escuta do outro ao mesmo tempo que imita a si próprio." (Socha, 2008).

Na fala materna, o sentido encontra-se na prosódia e não no conteúdo daquilo que é falado. Independente do discurso, o sentido da fala remete ao plano afetivo, como sugere Winnicott (2006, p. 85: "Ela pode sentir prazer em dizer: 'Dane-se, seu idiotinha' de um jeito agradável, de modo que se sinta melhor, e o bebê, encantado, lhe retribua com um sorriso. Ou, mais sutilmente ainda, que tal: 'oi, boi, boi, boi da cara preta, pega este menino...', que verbalmente não é lá muito agradável, embora seja muito doce como canção de ninar.”.

A afetividade e a adaptação ao bebê, observados pelo prisma do manhês, envolvem a criança em um cuidado construindo um espaço de confiança. Um ambiente seguro, capaz de fornecer aquilo que o bebê necessita, na qual a especularidade é um elemento essencial, faz com que o indivíduo encontre um lugar onde seja possível sua integração e construção do existir (Socha, 2008).

Na teoria winnicottiana, a capacidade materna de atender às necessidades em cada período do amadurecimento do indivíduo contribui para um desenvolvimento saudável. Dentro disto, a função especular da fala materna participa do processo de constituição do bebê e, quando ela não ocorre, não tendo o rosto da mãe como espelho, pode haver marcas significativas no processo maturacional. 
Socha (2008) cita algumas formas de fracassos de fala materna que podem acontecer na díade: a inexpressividade, a intrusividade e a impessoalidade. Vale salientar que estas classificações não têm um caráter tipológico causal, sendo utilizada aqui enquanto caminho ilustrativo para expandir nosso olhar sobre o tema, que é, muitas vezes, de difícil demonstração teórica.

Para ele, a inexpressividade seria a representação de uma fala que diz respeito somente a si mesma, caso de vozes depressivas ou maníacas, com dificuldades de se aproximarem da fala infantil. Nestes casos, a voz materna acaba se tornando um objeto externo impassível de ser construído pelo bebê e a realidade objetiva toma conta do lugar da apercepção criativa, experiência subjetiva do bebê em relação à sua mãe e ao ambiente que a cerca.

Quando a esperança se encontra drasticamente reduzida, o bebê humano deixa de se deslumbrar com a melodia da voz materna, restando apenas ruídos sonoros. Privada da possibilidade de criar a externalidade, a criança tem a experiência precoce de uma realidade objetiva. O mundo externo não concebido previamente pela criança lhe causa uma profunda sensação de irrealidade, visto que o self verdadeiro não é encontrado em parte alguma (Socha, 2008).

Já a intrusividade é caracterizada pela falta de um silêncio comunicativo, onde os gestos do bebê não são levados em consideração, não havendo sincronismo nos jogos sonoros, o que acaba por ocasionar a morte do gesto criativo e a criança tem um espaço propício para defesas de falso self. E finalmente a impessoalidade da voz representaria uma não identificação do bebê com a subjetividade materna, uma mãe que fala, porém não está presente, sendo complexo pensar na construção de um lugar do bebê no mundo sem que este último encontre um lugar na subjetividade do outro (Socha, 2008).

A protoconversação possui um importante papel na relação mãe-bebê e é a partir dela que a criança se insere na linguagem, em um processo de troca de turnos entre o par. Sabe-se que os distúrbios de comunicação estão atrelados à interação com a figura materna (ou cuidador principal), na medida em que a instauração da linguagem passa pela presença de um outro, que toma as manifestações da criança como significativas. É a partir deste movimento que o bebê vai se constituindo psiquicamente, com este diálogo intersubjetivo entre mãe-bebê.

A seguir, realizarei uma descrição de três cenas filmadas na qual as vozes maternas puderam ser classificadas como inexpressiva, intrusiva e impessoal, de acordo com Socha (2008) 
com a finalidade de nos aproximarmos das duplas e compreendermos melhor este processo relacional de trocas sonoras, observando mais atentamente a relação entre mãe e bebê pelos olhares dos autores citados.

Todas as duplas foram identificadas com dificuldades pelo SEAL e IRDI- Indicadores de Risco ao Desenvolvimento Infantil (que será exposto no capitulo 4 - Instrumentos de avaliação). Dentro do universo amostral total da pesquisa, 9 mães-bebês foram identificadas com dificuldade de desenvolvimento pelo IRDI e com dificuldade de linguagem pelo SEAL, 6 correspondendo ao grupo caso, possuindo um irmão mais velho com diagnóstico de TEA e 2 do grupo controle, sem irmãos com o diagnóstico. Uma cena onde há um encontro positivo e a dupla não se encontra em dificuldade (por qualquer um dos instrumentos) também será apresentada, totalizando 4 cenas. Todas as díades foram renomeadas de forma a prezar pelo sigilo.

\subsubsection{Cena 1: Esther e Mariah (11 meses)}

Mariah (mãe) e Esther (filha) estão em um quarto, com espaço livre e iluminado, tendo disponível uma caixa lúdica, com brinquedos variados. Mãe pega a cestinha com panelas e utensílios de cozinha e abre na frente da filha, colocando os objetos ao chão, silenciosamente. A bebê explora a cesta, dá alguns brinquedos para a mãe, outros coloca ao chão, em alguns momentos parecem disputar alguns brinquedos, mãe quer que fique de um jeito e ela de outro, a interação se dá sem som entre as duas. Segura uma panelinha oferecida pela mãe, sacode as perninhas, oferece à pesquisadora, porém (sem resposta), volta o brinquedo ao chão. A cena é marcada pela inexpressividade verbal. Encontra colher e leva à boca. Mariah mostra-se atenta aos movimentos da filha, verbaliza bem baixinho algo, sendo impossível de compreender aquilo que fala. Esther segue em silêncio, sem dirigir seu olhar à mãe. Mariah, de forma baixa e recatada, pergunta à pesquisadora se pode pegar outros brinquedos, e, com o consentimento, apresenta à filha uma boneca; a bebê dirige seu olhar à boneca, mas não se interessa, se concentrando em colocar a colher à boca. A mãe pega outros brinquedos da caixa e mostra à filha, que faz intenção de pegar, porém a bebê volta a colher à boca. Mãe apresenta carrinhos e bebê parece interessada, o olhar da filha sempre se dirige aos brinquedos, nunca à mãe. A cena segue permeada pelo silêncio verbal. Esther novamente estica uma das mãos e oferece um brinquedo à pesquisadora, que não dá resposta conforme a orientação estabelecida, a de intervir o mínimo possível. Mariah pega uma corrente de bolinhas brilhantes (como aquelas que se enrolam em árvores natalinas), bebê se interessa, larga a 
colher e leva a corrente à boca, sacode no chão, parece sentir e experênciar o barulho do brinquedo, que quebra com o silêncio da dupla; mãe acompanha com o olhar, sem verbalizar. Fim da cena.

Nesta breve vinheta, na qual a díade corresponde ao grupo caso, vemos que Esther reage às convocações maternas, porém sem iniciar uma interação e dirigir seu olhar à mãe. A bebê não se expressa verbalmente ou realiza qualquer tipo de ato sonoro, foca-se na exploração dos brinquedos da caixa lúdica (preferência ao jogo de panelinhas) levando-os à boca. Parece haver uma ação simbólica em seu brincar, contudo sem jogo simbólico. Mãe e filha, em muitos momentos, se perdem ao longo da filmagem, por entre os objetos, não havendo vitalidade e reciprocidade neste encontro. Mariah possui uma voz quase inexistente, muito baixa e pouco atrativa para captar a atenção da bebê e enlaça-la em um encontro duradouro. A voz materna, como nos diz Anzieu (1976) é considerada por suas qualidades vocais e pelos tempos de trocas sonoras, que servem como organizadores temporais e do espaço relacional entre mãe e bebê, a fim de que em um outro momento, a voz exista sem a presença visual da mãe, permitindo uma relação mesmo na ausência física.

Tomando como base as indicações citadas por Socha (2008), em referência aos fracassos de fala materna, percebemos uma fala inexpressiva, incapaz de se aproximar da fala infantil e captar a atenção de Esther, que se mostra mais interessada pelos objetos do que pelo encontro com a mãe. O deslumbre pela fala materna se reduz e a criança fica impedida de criar, se apropriando da realidade objetiva de forma precoce como afirma o autor: "o mundo externo não concebido previamente pela criança lhe causa uma profunda sensação de irrealidade, visto que o self verdadeiro não é encontrado em parte alguma" (Socha, 2008).

A cena explicita uma relação desencontrada, em que Esther e Mariah não conseguem construir um ritmo interacional, gerando empobrecimento e (des) vitalidade neste encontro. Diferenças culturais igualmente precisam ser levadas em consideração, neste caso, sabemos que Esther é de família imigrante e nos é colocada a questão das possíveis variações culturais de fala que alterariam nossa classificação inexpressiva, apesar do encontro desarmônico entre as duas.

\subsubsection{Cena 2: Sabrina e Ana (9 meses)}

Mãe (Ana) e filha (Sabrina) estão na sala de casa, em uma estante à frente encontram-se alguns brinquedos ao alcance de Sabrina. Ana segura o braço da filha e lhe apresenta uma boneca, 
silenciosamente. Sabrina se esquiva e a mãe chama-a em tom baixo, porém a bebê se vira para a estante com os brinquedos. Ana faz soar a boneca (fala frases) e coloca ao lado da filha, que se vira para escutar a boneca e sorri. Sabrina volta-se para a estante, a mãe a segura; tenta coloca-la sentada, mas a bebê engatinha para os brinquedos e pega uma mamadeira de brinquedo, levando-a a boca. A mãe reposiciona a filha, próxima a ela, parece falar algo (fica difícil identificar se é com a pesquisadora ou com alguém fora da cena). A bebê leva a mamadeira à boca, fazendo um movimento de morde-la e balbucia com intensidade. Ana retira a mamadeira da mão da filha, segura seus braços e depois tenta coloca-la em pé. Sabrina parece esparramar-se pelo chão, alcança um outo objeto de plástico (embalagem de shampoo) e a leva à boca. A bebê senta, Ana tenta levanta-la, mas a bebê novamente senta. A mãe diz em tom baixo, sem manhês: "ih, acho que ela não quer levantar não" (sic mãe). Sentada, Sabrina une suas mãos e a mãe tenta imita-la, batendo palmas perto de seu rosto. Sabrina mexe as mãozinhas (parecendo coça-las) e pega novamente a embalagem de shampoo. A mãe resgata a boneca e aciona o som, oferece a filha, que não se interessa. Segura a filha, que faz um movimento de sair e Ana oferece outro brinquedo (coelho de pelúcia). A Bebê balbucia, pega a boneca e leva o cabelo da boneca à boca, mãe retira. Ana olha para a câmera, a bebê faz movimento de engatinhar e a mãe a puxa de volta, segurando-a pelas pernas. A bebê reclama forte, a mãe a pega e coloca-a de pé, segurando seus braços. A bebê balbucia, faz um movimento de sentar e olha para a pesquisadora (fora de cena). Ana verbaliza algo, mas é difícil de compreender, sua voz é monótona e sem intencionalidade, chama pela filha. A bebê faz movimento de engatinhar e a mãe puxa-a pelas pernas novamente, Sabrina reclama forte. A mãe a coloca no colo, Sabrina novamente se incomoda e tenta se esquivar da mãe. A cena finaliza com a bebê indo engatinha fora do foco e a mãe tentando pega-la novamente.

Ana e Sabrina são também uma dupla mãe-bebê da segunda subfaixa e do grupo caso; notase uma grande dificuldade de sincronismo ente mãe e filha. Poderíamos classificar a voz de Ana como inexpressiva e ao mesmo tempo impessoal, já que as ações de Sabrina não são levadas em consideração. A mãe reconhece em alguns momentos as demandas de Sabrina, como a de que talvez ela não queira ficar em pé, porém não foi capaz de alterar seu agir e encontrar um ritmo comum de brincadeira. Ana dá uma sensação de descolamento da cena, parecendo escutar grande parte do tempo somente a si, possuindo uma fala que não encontra lugar, visto sua falta de 
vitalidade de direcionamento. A inexpressividade parece vir da dificuldade de se aproximar da fala infantil e de executar o manhês.

Ana possui um filho mais velho com autismo e a literatura refere o desamparo materno e aumento de chances de ocorrência de sintomas de depressão, ansiedade e estresse nos pais ao cuidarem de um filho com TEA. Lerner (2011) evidencia em bebês, posteriormente diagnosticados com autismo, intensa reação defensiva de afastamento dos pais para com estas crianças, entre $12 \mathrm{e}$ 18 meses de vida. É ainda discutido o estado de sideração parental por dificuldades de trocas entre pais e filhos com autismo (Crespin, 2004), devido à capacidade de apropriação dos pais por certas características da própria patologia, além da sobrecarga de cuidados oferecidos.

Já Sabrina se coloca na cena e consegue expressar suas vontades, apesar da aparente dificuldade motora de colocar-se sentada, algo esperado para sua idade de 9 meses. Este atraso já foi apontado pela literatura, que será posteriormente exposta ao falarmos de irmão de crianças com TEA, ligando atrasos motores a problemas futuros de linguagem.

Ana é uma mãe com comportamento intrusivo e com uma voz inexpressiva e impessoal, que nos faz refletir do quanto, muitas vezes, a voz e o comportamento podem se desenvolver sobre aspectos distintos. A vitalidade e imposição das ações físicas de Ana não se expressam em sua voz, que se mostra frágil, sem picos prosódicos e desconectada com os desejos da filha. A dificuldade de descrição daquilo que é ouvido se faz presente na construção da vinheta, já que saltam aos olhos principalmente o comportamento, que não é refletivo na voz, no que é ouvido/ não ouvido na filmagem. Está aí um desafio nas descrições: como ambientar o leitor com algo que foi unicamente ouvido? Como expressar o som, sua ausência e intensidade? Questões talvez que os literários saibam melhor responder.

\subsubsection{Cena 3: Fabi e José (6 meses)}

Mãe encontra-se com o filho nos braços, voltado para si, estão em uma poltrona, em um ambiente externo da casa, ao lado uma fonte de água que traz um barulho sereno à cena. Fabi chama o filho delicadamente, falando para ele levantar a cabeça e olhar para ela. O bebê, em seus braços, encontra-se com a cabeça e olhar voltados para baixo. A mãe levanta-o mais para cima, volta a falar com José, para que levante a cabeça e tenta chamar a atenção dele para a fonte, ao seu lado. Com alegria a mãe diz, “olha lá, viu?”. Pega um vasinho de flor, coloca-o próximo ao rosto de José, que não se mostra interessado. Sacode o filho no colo em uma brincadeira, perguntando 
frequentemente e com manhês por que José não quer olhar para ela; o bebê olha para cima, abre a boca e parece sentir a intensidade da brincadeira. "Você está com raiva porque a mamãe acordou ele, né" (sic), e segue dizendo ao filho "você acordou eu e não deu peitinho" (sic), dando um beijo nele. Chama o filho para brincar de cerra-cerra-cerrador, deitando-o no colo. A cena segue com a brincadeira, José abre a boca e franze o rosto, exprimindo um aparente sorriso, parece gostar. Mãe pega as mãos do filho e canta junto com ele parabéns, com certa energia. José olha para cima, esboça sorriso, Fabi beija as mãos do filho, que fixa o olhar em suas próprias mãos e depois se perde, abaixando a cabeça. Fabi segura José mais alto e o sacode moderadamente no ar, dizendo com intensidade "levanta esta cabeça, menino! Ah se você ver este celular você não vai mais olhar para a mamãe, né?", a partir de um olhar fugaz de José para a câmera. O Bebê segue com o olhar e cabeça caídos, a mãe tenta apresentar o vaso de flor novamente, mas sem resposta, deixa o objeto ao lado. Dá um beijo no filho e o coloca nos ombros. O bebê põe a mão na boca e olha para a câmera, Fabi pergunta com delicadeza, beijando-o “o que está olhando? ”. Vira o filho de frente e brinca com suas mãos, José boceja. A mãe intensifica a brincadeira com as mãos e José balbucia. Brinca de esconde-esconde com as mãos do filho, ficando neste jogo por um tempo, José volta a balbuciar. A mão retorna o filho para si, buscando seu olhar e volta a dizer, com manhês "olha para mim, você não vai olhar para mim? Eu não quero, mamãe! ”. José boceja e olha por entre os espaços, sem fixar seu olhar na mãe, boceja e volta a abrir a boca. A mãe conversa com o filho em manhês e depois fica em silêncio, balançando o filho no colo. Fim da cena.

Nesta descrição, vemos Fabi e José extremamente desconectados, José com sinais significativos de questões de desenvolvimento psíquico, expresso, entre outros, pela explícita recusa ao olhar materno. Dentre as categorias de Socha (2008), podemos classificar a voz materna como intrusiva pela falta de um silêncio comunicativo, que abriria espaço para as comunicações do bebê. Porém vale notar que José é uma criança que pouco responde aos chamados desta mãe, que insistentemente lhe convoca na tentativa de obter alguma reposta mais significativa, chamando-o ao encontro. Podemos aqui até pensar em expandir as categorias de Socha (2008) e criar uma nova categoria, da 'mãe desinvestida', que insiste em um encontro e torna-se intrusiva devido à falta de investimento do bebê nela própria/relação.

A falta de diálogo intersubjetivo entre Fabi e José, da primeira subfaixa e do grupo controle, preocupa e os coloca como uma díade em dificuldades, na medida em que não parece haver uma 
troca emocional ente os dois. Ao se pensar nos vínculos, refletimos sobre o papel interativo do bebê junto à sua mãe, como refere Winnicott ao descrever o processo de desenvolvimento infantil. Fabi é afetuosa em sua fala, executando prosódia adequada na tentativa de se aproximar afetivamente de José, se não fosse suas excessivas intervenções na tentativa de captá-lo. José parece, em quase toda a filmagem, indisponível para experênciar estados emocionais compartilhados com sua mãe.

\subsubsection{Cena 4: Carla e Bruna (4 meses)}

Carla (mãe) está finalizando a troca de fralda de Bruna (filha) em um trocador no quarto da bebê. Mãe e filha se olham e Carla diz “minha gorducha linda, minha gorducha linda!” (sic), esta segunda vez em um pico prosódico mais alto. Bruna olha para a mãe, sacode o corpo e sorri, colocando a língua para fora. A bebê balbucia, mãe a olha e diz a filha "Ah, é? Você é cheia de história para contar, né, filha! Cheia de conversa". A bebê balbucia novamente e olha para a mãe, que responde "Aguuu" e a bebê continua a balbuciar, explorando com o olhar o quarto e levando a mão à boca. Carla segue dizendo "converso com a minha mão, é isso que você faz" e se aproxima do rosto da filha, no intuito de beija-la. A bebê sorri e balbucia, sacudindo as pernas. "Tudo isto você tem de história para contar?”. A bebê leva a mão à boca e Carla diz, “chupando o dedo, é, a titia disse para eu não deixar", se aproximando corporalmente a filha, que sacode os braços e o corpo, balbuciando. Mãe se aproxima da filha e faz carinho em seu corpo e em seu rosto. Mãe pega um brinquedo e oferece à filha, que pega com sua mão. A mãe a auxilia e diz "esta semana aprendi a pegar brinquedo", mãe e filha se olham. A bebê ameaça reclamar e mãe a pega no colo, uma outra criança chega no quarto e a bebê lhe dirige o olhar. A cena termina.

A vinheta expressa um encontro marcado pelo contato afetivo, intersubjetivo, que se expressa através da comunicação não verbal, composta pelas trocas sonoras, prosódia, ritmo, intensidade vocal, trocas de olhar, imitação e capacidade empática materna. Seguindo os passos de Socha (2008) poderíamos criar novamente e categorizar esta fala como "intersubjetiva". Vemos a afetividade expressa por meio nas inflexões vocais e as mudanças tonais são transmissoras de aspectos ligados à agressividade e a sexualidade, como sugere Ogden (1998). É dentro deste contexto, envolvido pela sonoridade, fazendo referência ao envelope sonoro (posteriormente desenvolvido) de Anzieu (1976), que a subjetivação se constrói, permeada de silêncio e som. 
Nesta cena fica clara a confiança de Bruna no ambiente, sendo Carla capaz de atender às necessidades da filha e a captar possível desconforto que aparece ao final da filmagem. Um ambiente constante, de acordo com Winnicott, promove confiança no bebê e dá condições para que esta criança construa uma realidade para além dela. O rosto da mãe se faz como espelho, havendo a mutualidade de experiências, aqui marcadas pela ritmicidade do encontro, marca primordial para a entrada na linguagem.

Esta ritmicidade entre a gestualidade do bebê e a linguagem da mãe dirigida a ele, faz com que as manifestações do filho se transformem em palavras, com significados, construindo o caminho de entrada na linguagem pela criança: há o reconhecimento de um $e u$, que institui um tu e trabalha na subjetivação deste $t u$, dentro de uma singularidade que se expressa em cada ato de enunciação, temas que serão explicitados mais a frente. 


\section{CAPÍTULO 2: COMPORTAMENTO VOCAL NO TRANSTORNO DO ESPECTRO DO AUTISMO (TEA)}

\subsection{BREVES CONSIDERAÇÕES SOBRE O TEA}

O autismo infantil foi descrito por Leo Kanner em 1943 a partir do relato de onze casos de crianças que apresentavam significativa tendência ao retraimento, diferenciando-a do retardo mental e tendo como principais características início na primeira infância; perturbações das relações afetivas com o meio; solidão extrema; inabilidade no uso da linguagem para a comunicação; manutenção rígida de rotinas; presença de boas potencialidades cognitivas e incidência predominante no sexo masculino. Tais descrições tiveram grande impacto na literatura mundial e foram rapidamente absorvidas pela comunidade científica. A abordagem etiológica do autismo infantil posposta por Kanner ainda salientava a existência de uma distorção do modelo familiar decorrente do alto caráter intelectual dos pais, que ocasionaria alterações no desenvolvimento psicoafetivo da criança, além de pontuar sobre a influência do fator biológico destas, já que as alterações de comportamento eram verificadas precocemente, se chocariam com a hipótese puramente relacional. A partir disto, inúmeros trabalhos foram desenvolvidos, passando a se discutir os conceitos do autismo sob diferentes pontos de vista teóricos, entre eles o de se distinguir terminologicamente o autismo, a esquizofrenia e a psicose infantil.

A terminologia autismo é referenciada para se tratar de quadros clínicos variados, com sintomatologias similares, que são agrupadas de diferentes maneiras. Na quinta versão do Manual Diagnóstico e estatístico das Doenças Mentais - DSM, o diagnóstico para o autismo compele quatro distúrbios até então separados (Autismo, Síndrome de Asperger, Transtorno Desintegrativo da Infância e Transtorno Global ou Invasivo do Desenvolvimento sem outra especificação) dentro deste mesmo diagnóstico: o Transtorno do Espectro do Autismo (TEA). Fazem parte do espectro os quadros com dificuldades na interação e na comunicação social, e presença de interesses restritos e/ou comportamentos repetitivos. Na décima revisão da Classificação Internacional de Doenças CID 10, os Transtornos Globais do Desenvolvimento foram classificados como um grupo de alterações caracterizado por alterações qualitativas da interação social e modalidades de comunicação e por um repertório de interesses e atividades restrito e estereotipado. Neste caso, o Autismo Infantil caracteriza-se por um desenvolvimento anormal ou alterado, manifestado antes 
dos três anos de idade e que apresenta perturbações no funcionamento das áreas de interação social, comunicação e comportamento repetitivo, tendo uma incidência populacional em torno de 2-5 indivíduos para 10.000, com predomínio do sexo masculino (CID-10, 1994).

Apesar da diferença entre os estudos, principalmente em decorrência das variações do critério, conceito diagnóstico e instrumentos utilizados, houve intensa elevação dos dados de prevalência de TEA pelo mundo nas últimas décadas, crescimento que pode ser justificado tanto por esta nova configuração do diagnóstico, como pela idade da detecção, maior conhecimento do transtorno pelos profissionais de saúde pública, mudanças nos serviços e políticas públicas, além de um possível aumento real dos casos. O Centro de Controle e Prevenção de Doenças dos Estados Unidos (Center for Desease Control and Prevetion - CDC) apontou uma prevalência de um caso para cada 110 crianças, e em 2015 a estimativa foi de um a cada 68. No Brasil, o único estudo indica taxa de ocorrência de $0,3 \%$ na população geral, sendo que a amostra reduzida pode ser uma das justificativas a esta menor expressividade, apesar de que o único outro estudo realizado na América Latina, também encontrou baixa prevalência (17 para 10.000) em comparação com outros estudos pelo mundo. Ainda é pouco clara a influência cultural, étnica, geográfica e sócio econômica associadas ao TEA, sendo que a maioria dos estudos foram realizados na América do Norte, Norte da Europa e Japão, com certa escassez de pesquisas transnacionais (Paula et al, 2011).

No meio psicanalítico, em 1930, Melanie Klein já havia trazido suas observações e traçado conjecturas a respeito de seu paciente Dick, apesar de ela não o considerar com autismo. Os sintomas descritos por Klein iam ao encontro do que Kanner posteriormente descreveria como autismo infantil precoce. O universo particular das crianças com autismo também foi estudado por Margareth Mahler (1982), com seus estudos de separação-individuação; Esther Bick (1991[1968]), com o conceito de segunda pele; Donald Meltzer (1984; 1986); France Tustin (1984; 2018); Anne Alvares (1994), além de Marie-Christine Laznik (1995) com seu olhar para a prevenção e intervenção o mais breve possível e GenevièveHaag (2008). Todos estes estudiosos aqui citados refletem o quanto ter uma criança com este diagnóstico desperta a necessidade de conhecimento e cuidado, pois envolve uma série de fatores interatuantes, intra e extrafamiliares, que exigem dos serviços de saúde e dos profissionais olhares e cuidados não só para a criança, mas também para toda a rede familiar, que se encontra diretamente impactada.

Além da psicanálise, existem outras formas de se compreender o autismo. Acredita-se na possibilidade de uma causalidade múltipla para o transtorno, que inclui os estudos de Epigenética, 
correspondendo à interação entre fatores genéticos e ambientais. Os genes candidatos e regiões genômicas estão sendo avaliados pelo seu papel potencial no autismo, sendo que a evidência de uma base genética é fornecida pela coocorrência de autismo dentro das famílias de sangue, apesar da variação das frequências encontradas. Wassink et al (2001) encontraram uma taxa de concordância de $100 \%$ para o transtorno autista com gêmeos monozigóticos e $33 \%$ com gêmeos dizigóticos. Em artigo sobre genética do espectro do autismo, Geschwind (2011) afirma que dezenas de genes de susceptibilidade ao transtorno em questão foram identificadas nas últimas décadas, representando 10-20\% dos casos diagnosticados e que tais achados demostram a heterogeneidade da etiologia do TEA, além de importantes caminhos para a compreensão de sua fisiopatologia. O autor segue dizendo que a variância de abordagens genéticas e genômicas das pesquisas evidenciam rupturas das principais vias biológicas e que igualmente estão implicadas em outros distúrbios de desenvolvimento neurológico.

Outro estudo afirma uma maior prevalência de distúrbios do espectro do autismo entre irmãos não gêmeos se comparados a taxas na população em geral (Ritvo et al., 1989; Smalley, 1997). Foram encontradas maiores dificuldades comportamentais e menos comportamentos considerados pró sociais em irmãos (4 -16 anos) de crianças com autismo, se comparadas com amostras normativas. Porém, estudos ainda indicam não possuirem dados conclusivos para se afirmar que irmãos de crianças com autismo têm um prejuízo maior do que irmãos de crianças com outros diagnósticos mentais que sejam diferentes do autismo (Goldberg, Jarvis, Osann et al, 2005).

\subsection{COMPORTAMENTO VOCAL NAS CRIANÇAS COM TEA}

No que tange ao autismo, as alterações comunicativas estão presentes nas primeiras descrições do transtorno e geralmente se apresentam como uma das principais queixas dos pais, já que acabam por impactar na inserção social e cultural dos indivíduos, se caracterizando enquanto componente fundamental da composição do quadro clínico (Sousa et al., 2009). A questão da comunicação e linguagem nos diagnósticos de TEA se mostra igualmente de suma importância, sendo um fator importante na avaliação do prognóstico (Fernandes, 2009).

Quando existe uma boa descrição da história social primeva da criança e o uso de objetos, o diagnóstico de autismo pode ser feito sem referências aos atrasos de linguagem (Cohen et al., 1993; Siegwl et al., 1989). Porém o nível de linguagem expressiva aos 5 anos de idade é um importante 
descriminante de alto ou baixo funcionamento de crianças mais velhas e adultos com TEA, sendo pouco preditiva uma caracterização da história de linguagem para esta análise (Howlin et al., 2004).

Estudos indicam que grande parte das famílias descrevem as alterações de linguagem próximo dos 2 anos de idade, já que é neste momento que um desenvolvimento significativo é esperado. (Sousa et al., 2009), sendo que as crianças com TEA são raramente diagnosticadas antes dos 3 e 4 anos de idade (Charman \& Baird, 2002; Filipek et al., 1999; Fombonne, 2005). Porém Fernandes (2003) afirma que desde o primeiro ano de vida os pais já se mostram sensíveis às variações de comportamentos das crianças, que realizam pouco contato visual, baixa reciprocidade no encontro com o outro e na busca por este outro, além de baixa frequência de balbucios.

O pouco contato visual, falta de responsividade aos chamados parentais e baixo interesse na interação e no brincar são também identificados por alguns pais de crianças com TEA antes do primeiro ano de vida. Além de dificuldades de comunicação como atrasos no uso de gestos e dos balbucios, percebidos antes do início das verbalizações (Mitchell et al, 2006).

Em estudos de identificação parental nos significados das vocalizações pré-linguísticas em crianças pré-escolares com TEA, foram encontradas incapacidades parentais de compreender as mensagens tanto de outras crianças com TEA, como de seus próprios filhos. Situação não ocorrida com os pais de crianças sem o diagnóstico estudado ( Wing \& Wing 1976).

Pesquisas ainda encontraram em crianças com menos de 1 ano de idade, que posteriormente se tornaram autistas, uma menor responsividade aos próprios nomes ou a alguém falando se comparada com outras crianças (Lord, 1995) e uma menor responsividade também à voz materna (Klin, 1991).

As manifestações comunicativas circulam por um grande espectro de variações, apresentando-se de diferentes maneiras, interferindo igualmente na forma como os pais e cuidadores lidam e percebem tais dificuldades. Muitos estudos descrevem as características comunicativas de crianças com TEA entre o segundo e terceiro ano de vida, sumarizando alguns achados que incluem: padrões de olhar anormal; referenciamento social e compartilhamento de afetos limitados; baixa frequência de atenção compartilhada, apontando ou comentando; resposta inconsistente ao nome; baixa frequência de comunicação não verbal; falha nas respostas ou uso de gestos convencionais; faz de conta limitado (limited pretend play); restrições motoras e na imitação 
vocal; interesses diminuídos em pessoas e jogos interativos; atraso no desenvolvimento inicial e na linguagem verbal e vocalizações incomuns (Volkmar, Chawarska \& Klin., 2005).

Outras pesquisas demostram que além das dificuldades comunicacionais, as crianças com TEA apresentam em sua maioria importantes atrasos no processo de aquisição da linguagem falada (Tager-Flusberg, Paul \& Lord, 2005), tanto quanto nos aspectos fonológicos e outras características vocais em crianças pequenas.

Estudos que analisam erros fonéticos e fonológicos em crianças autistas de alto funcionamento e Síndrome de Asperger, entre cinco e 13 anos, através de testes de articulação padronizados, encontraram uma taxa de $12 \%$ da amostra com atrasos de fala/desordem. Dos 69 sujeitos (30 com autismo de alto funcionamento e 39 com Síndrome de Asperger), 28 dos sujeitos produziram erros pelo instrumento GFTA-2. Destes 28, 20 foram erros dentro da taxa dita normal e 8 tiveram erros fora da taxa normal. Um distúrbio de linguagem pode ser expresso através da fala e/ou escrita; por caráter receptivo (compreensão) e/ou expressivo (fala, leitura, escrita). Os erros considerados de desenvolvimento da fala incluem deslizamentos, redução grupal fonológica e exclusão de consoante ${ }^{3}$. Já os erros não desenvolvimentais seriam os de emissão de fonemas nasais específicos e supressão da consoante inicial, que foram encontrados tanto em crianças que obtiveram performance abaixo do normal nos testes de articulação padronizados, como nas crianças com scores dentro da média. Os resultados indicam que a minoria das crianças com autismo apresentou taxa abaixo do normal esperado em testes de articulação. Os erros indicariam um distúrbio de fala, e não propriamente de linguagem. Se os distúrbios da fala estão relacionados especificamente ou não ao TEA, sua presença inclui uma importante barreira social e comunicacional, sendo de suma importância o tratamento o mais cedo possível para as crianças (Cleland et al., 2010).

Bebês que desde o nascimento até os 3 meses não sorriem ou interagem com outros; que dos 4 aos 7 meses não balbuciam; que vocalizam pouco ( 7 a 12 meses); não fazem uso de gestos (7 a 12 meses); não compreendem aquilo que os outros dizem (7 meses a 2 anos); dizem somente poucas palavras (12 a 18 meses); são incapazes de formar sentenças (1 ano e meio a 2 anos); dizem menos de 50 palavras aos 2 anos; tem dificuldades de interagir/ brincar com outras crianças (2 e 3 anos) e não apresentam nenhum interesse para livros e desenhos/garatujas (2 anos e meio a 3 anos) podem ser indicativos de alguma desordem linguística (ASHA. Org, 2018).

${ }^{3}$ Distúrbios articulatórios que envolvem trocas fonéticas ou mesmo omissão de sons. 
Ao pensarmos em marcos de desenvolvimento típico de linguagem espera-se que crianças entre 12 e 15 meses de idade, em termos semânticos, expressem-se com uma média de 10 palavras e uma média receptiva de 50 palavras, com estratégias de compreensão de nomear objetos e usa-los de acordo com suas finalidades. Na sintaxe, é ansiado que as primeiras produções sejam de palavras-chaves únicas, as holofrases; uma palavra que carrega a força de toda a sentença. E na fonologia, é esperado que a criança use CV ou CVCV (consoante-vogal ou consoante-vogalconsoante-vogal), como exemplo: Ba ou mama/papa. Na pragmática ${ }^{4}$ é desejado que a criança expresse pedidos e comentários, sendo a comunicação acompanhada de gestos com vocalizações de fala. (Tager-Flusberg, Paul \& Lord, 2005).

A deficiência auditiva aparece como uma das primeiras hipóteses para compreender a ausência de balbucio e inconsistência à reciprocidade aos estímulos parentais e ambientais, porém esta identificação a termo está muito atrelada à atenção profissional e às expectativas da família frente ao seu filho.

Há escassa literatura sobre como se estabelece o processamento auditivo em crianças com TEA, cabendo destacar aspectos emocionais, sociais, orgânicos e cognitivos ao se refletir sobre a linguagem, devendo se considerar estes elementos nas investigações e intervenções terapêuticas. (Fernandes, 2003).

O desenvolvimento da linguagem até os 5 anos de idade está diretamente relacionado aos progressos futuros infantis, sendo a linguagem um significativo marcador de prognósticos nos casos de TEA. O relato de familiares e a detecção de sinais realizadas por profissionais da puericultura se fazem extremamente necessários aos pensarmos em intervenção a termo.

Sabe-se do quanto a presença de uma criança com o diagnóstico influencia no estado emocional parental, e estudos sobre coparentalidade de pais de crianças com autismo indicam necessidade de intervenções na dinâmica familiar, a fim de auxiliar as atividades da vida do casal e diminuir a sobrecarga materna, reduzindo por consequência o estresse (Sifuentes \& Bosa, 2010).

Nos cuidados de crianças com autismo Araújo (2003) refere-se ao desamparo materno, até mesmo antes da gravidez, como um dos fatores que interferem significativamente na capacidade de um ambiente dito como suficientemente bom. Se faz essencial a existência de um ambiente/mãe capaz de sustentar e acolher as necessidades do bebê em cada período de seu desenvolvimento.

\footnotetext{
${ }^{4}$ Ramo da linguística que analisa o uso concreto da linguagem pelos falantes da língua em diversos contextos, sendo que o uso e efeito prático que os atos de fala podem gerar são mais importantes do que a semântica ou sintaxe.
} 
Um grande número de dados sugere que um ambiente social e linguístico com pais e professores ativos e amorosos acabam por ser um diferencial a essas crianças. Déficits iniciais de aquisição de linguagem ou fatores sociais ou cognitivos afetando a linguagem podem compor diferentes experiências de linguagem, sendo que a raiz destas diferenças pode estar associada a oportunidades de repertórios de linguagem que os mais velhos oferecem aos mais novos (TagerFlusberg, Paul \& Lord, 2005., p. 335/336).

A necessidade de um olhar atento por parte dos profissionais da saúde se faz de suma importância, a fim de valorizar os relatos familiares e estabelecer um cuidado não só para o eixo formal da linguagem, mas para a qualidade da interação, compondo aspectos de intencionalidade e reciprocidade da díade, principalmente. Os instrumentos utilizados nesta dissertação se propõem a captar tais aspectos, já que se sabe o quanto tal problemática é componente dos processos intersubjetivos do bebê, fator de imprescindível atenção nos âmbitos de prevenção, promoção e tratamento.

\subsection{UM GRUPO QUE MERECE ATENÇÃO: IRMÃOS}

Os irmãos de crianças com autismo se configuram enquanto grupo de risco ao transtorno e outros problemas de desenvolvimento. Daí a necessidade de olhar para esta população, intuito desta e da grande pesquisa do qual este mestrado se origina, já que há uma taxa de recorrência estimada entre 6,9\% e 21\% nestes irmãos (Ozonoff et al., 2011; Messinger et al.,2013; Sandin et al., 2014). Além disso, há um aumento duplicado se mais de um irmão possuir autismo e este risco amplia em três vezes se o bebê for do sexo masculino (Ozzonoff et al., 2011); sabendo também que daqueles que não possuíram o diagnóstico 25-50\% podem desenvolver atrasos motores, sociais e de comunicação (Bailey, Phillips, \& Rutter, 1996).

Para Teixeira Caldas Campana \& Lerner (2014) mães que tiveram um primeiro filho com autismo tendem a apresentar marcas significativas na função materna, que podem se refletir na relação estabelecida com seus outros filhos. Em algumas situações, a capacidade da mãe de reconhecimento do desejo em seus filhos pode se encontrar mais fragilizada, porém, se oferecido um espaço de escuta, estas mães são capazes de se descolarem deste aparente destino, assim como os irmãos, apesar da maior vulnerabilidade ambiental.

As poucas experiências de reciprocidade entre mãe e bebê com autismo podem provocar nestas mães sentimentos insuportáveis de serem elaborados emocionalmente na relação devido a dificuldades de integração com os estados mentais um do outro, o que dificulta os cuidados de um 
bebê, recém-chegado à família. A criança com autismo possui mais entraves para estabelecer uma relação de sintonia afetiva, onde recompensas e gratificações são vivenciadas com mais intensidade.

Araujo (2010) ainda fala de uma suspensão de investimentos e capacidades parentais em pais que tiveram um primeiro filho com autismo, além de bebês irmãos que pouco solicitam a atenção e ajuda de seus cuidadores principais. A autora percebeu sintomas de ansiedade e pobreza simbólica nestes bebês, irmãos de crianças com TEA, que se expressam em um brincar mais empobrecido, restrito à nomeação dos objetos e suas funções e também em uma linguagem monossilábica, de perguntas e respostas, sem construção de frases.

Ao tratarmos destes bebês irmãos de crianças com autismo, um grupo de pesquisadores encontrou uma maior frequência de atraso motor nestes bebês se comparado a crianças do grupo controle (sem irmãos com TEA), além de que atrasos diversos de linguagem se desenvolveram em $67-73 \%$ dos irmãos que apresentaram atraso motor, supondo que problemas motores precoces podem ser preditivos para possíveis dificuldades comunicacionais em crianças com risco para autismo (Bhat et al., 2014).

Estudos sugerem que o surgimento dos gestos está intimamente ligado ao desenvolvimento da linguagem, além de que o desenvolvimento motor precoce fornece uma base para o desenvolvimento futuro da comunicação, no qual formas não verbais comunicativas incluem atos de motricidade final, ações motoras grossas e viradas de cabeça que visam o olhar (Gernsbacher, Stevenson, Khandakar, \& Goldsmith, 2008). Tais achados endossam a necessidade de se compreender a linguagem não somente enquanto aspecto verbal, mas como variante multimodal, no qual o corpo do bebê se coloca em importante destaque neste processo, conceituação aqui trazida também pela ideia de envelope sonoro de Azieu (1994), que será posteriormente melhor apresentada.

O grupo de Bath e de outros pesquisadores igualmente detectaram marcadores de comunicação social para o diagnóstico precoce de TEA: interrupção da comunicação não verbal, como baixa frequência de iniciação das respostas e atenção compartilhada entre díades mãe bebê (Sullivan et al., 2007; Landa, 2007; Yoder, Stone, Walden, \& Malesa, 2009); baixa reciprocidade na interação social e troca de olhares empobrecida durante os encontros, como também pouco afeto positivo compartilhado; além de atrasos na comunicação verbal, com redução das experimentações de consoantes, sílabas canônicas e palavras (Landa, 2007). 
Para estes irmãos de crianças com o transtorno, que já foram diagnosticadas com autismo, houve atraso de linguagem no primeiro e segundo ano de vida mesmo quando estes irmãos ainda não possuíam um diagnóstico estabelecido, sem compor critérios para o TEA (Paul et al., 2011).

Outro estudo que avaliou bebês aos 8 e posteriormente aos 36 meses que possuíam irmãos dentro do espectro do autismo encontrou uma taxa de $21 \%$ de TEA neste grupo de irmãos, sendo que muitos daqueles que fugiram ao diagnóstico, apresentaram dificuldades de desenvolvimento e alguns comportamentos ligados ao transtorno em questão (Messinger et al., 2013).

Landa et al. (2012), ao estudar irmãos de crianças com autismo entre 6 e 36 meses, evidenciaram bebês com rápido desenvolvimento (25,7\%); desenvolvimento típico (40\%); desenvolvimento típico com alguns atrasos motores e de linguagem e bebês com atraso no desenvolvimento após o sexto mês de vida. Todos os bebês irmãos que posteriormente receberam o diagnóstico de TEA apresentaram atrasos no desenvolvimento e se distribuíram entre todas as classes descritas, com exceção do grupo com desenvolvimento acelerado.

Tomados juntos, tais resultados evidenciam tanto problemas no desenvolvimento como também a presença de significativos atrasos na linguagem verbal e não verbal em crianças com risco para TEA no primeiro e segundo ano de vida, o que faz que os irmãos de crianças com o transtorno aqui exposto necessitem de um olhar cuidadoso por parte dos profissionais e estudiosos das mais diferentes áreas de trabalho e que os aspectos de aquisição de linguagem possam ser melhor compreendidos, como tal pesquisa aqui se propõe. 


\section{CAPÍTULO 3: AQUISIÇÃO DE LINGUAGEM E EMBASAMENTOS DO SEAL}

\subsection{CONCEITO DE ENUNCIAÇÃO E OUTROS ASPECTOS DA LINGUAGEM}

Sabe-se que a comunicação mãe-bebê tem um papel decisivo na construção no vínculo entre a díade; a boca se abre e é através dela que o contato corpo-a-corpo com a mãe se faz pela mamada, intermediada pela voz materna, que vem significar este cuidado junto com as inflexões inconscientes trazidas pelos afetos dos pais. A voz da mãe permite que o bebê deixe de ser apenas um corpo e passe a ser inserido em um simbólico, nomeando, distinguindo, celebrando o corpo do bebê e, desta forma, evocando sua existência. Uma voz que é escutada e compreendida pela criança antes mesmo de seu nascimento, que está envolvida por histórias de seus ancestrais (Szejer, 1999).

Parte-se da compreensão de que o humano está pautado na relação com o outro e, consequentemente, na linguagem, sendo que a constituição psíquica da criança é dependente dos processos interativos iniciais. É primordialmente a mãe que desempenha este papel e, a partir desta relação, o bebê se vê envolvido por esta fala materna, que o acolhe e o faz presente, permitido que ele esteja em diálogo e em sintonia com ela, mãe, mesmo sem a emissão de qualquer palavra.

Logo, o ato de instauração da criança na linguagem evidencia um espaço de enunciação, no qual a criança não desenvolve os mecanismos da língua, mas os constitui e por eles é constituída, simultaneamente. A linguagem surge na criança em um processo de atualização dos signos no diálogo com o tu (adulto), que a identifique como um $e u$, pois é necessário que haja a passagem de locutor à sujeito. Desta forma, a análise da linguagem no bebê implica na apreciação do lugar de fala que o adulto lhe concede. A entrada da criança no universo linguístico já é pautada por um mundo constituído, porém há uma construção deste mundo pelo bebê no processo de apropriação da linguagem, que evolui juntamente com o desenvolvimento desta criança, que passa a se perceber como pessoa, passando de uma autorreferenciação em terceira pessoa para primeira pessoa eu (Kruel et al., 2016).

Dentro da diversidade teórica do campo da Linguística, destaca-se nesta pesquisa a Linguística da Enunciação, tendo como objeto central o sujeito, diferenciando-se de outros tipos que não incluem a subjetividade do indivíduo como princípio de funcionamento da linguagem. Dentro da Teoria da Enunciação sobressaem autores como Charles Bally; Roman Jakobson; Émile Benveniste; Oswald Ducrot; Jacqueline Authier-Revuz; Antoine Culioli; entre outros, que mantém 
uma unicidade de pensamento pela orientação enunciativa a partir de Ferdinand de Saussure; pela intenção de definir o termo enunciação e foco no sujeito no tratamento da linguagem. Silva (2007, p. 141) afirma que os fenômenos estudados por esta teoria pertencem à língua, mas se expandem à fala, já que é somente através dela que a existência se dá, a partir do questionamento do existir de ambos. É por meio do uso da língua que o discurso se atualiza, configurando-se no estudo das representações linguísticas do sujeito na própria enunciação.

Silva (2007) ainda sugere que a criança como locutor irá apontar novas estruturas para aquilo que já é estabelecido dentro da língua, trazida pelo alocutário (pessoa a quem o locutor dirige o ato da fala), propondo três mecanismos enunciativos:

$1^{\mathrm{o}}$ Relações de conjunção e disjunção $e u$ e $e u / t u$ com transformação do lugar enunciativo partindo do outro para o reconhecimento que este lugar provoca no outro.

$2^{\circ}$ Semantização da língua (dar significado à língua) e construção de referência (eu-tu) / ele, onde há a passagem de uma referência mostrada para uma constituída na fala-discurso.

$3^{\circ}$ Instauração da criança na língua, onde há a passagem do uso discursivo por meio de funções e formas para a constituição da dupla enunciação: o discurso sendo constituído e formando um novo discurso.

Nesta pesquisa me aterei somente ao primeiro mecanismo, já que a amostra aqui utilizada se dirige a crianças de até 12 meses. Compreende-se deste processo que entre os primeiros meses de vida o bebê responde, por meio de comunicação não verbal, aos desígnios maternos convocados verbalmente: "Na relação de conjunção, o caráter de pessoa implica a constituição mútua de eu e de tu. Nas relações de disjunção, o eu institui o tu, rompendo a unidade da relação eu-tu e constituindo-se como pessoa subjetiva e oposição a tu, pessoa não-subjetiva" (Silva, 2007, p. 226). Como exemplos de relações conjuntivas, Silva (2007) traz o bater palmas da criança quando o adulto (tu) canta parabéns e a imitação sonora de crianças com os sons de animais. Já para relações de disjunção seria o momento quando se brinca de assustar o irmão e a criança diz "ah".

Ramos (2013) ainda exemplifica e expande este primeiro mecanismo descrito por Silva (2007) com a ligação entre a gestualidade do bebê e a linguagem da mãe dirigida a ele no processo de interpretação articulatória corpolinguagem do bebê: a mãe transformando em palavras as manifestações vocais e gestuais de seu filho que ainda não são língua. A partir deste processo, esta mãe permite que a criança acesse o sistema linguístico, inserindo-o simbolicamente na linguagem pela via da tradução das cenas corporais vividas pelo bebê. 
O principal instrumento deste trabalho, o Sinais Enunciativos de Aquisição de Linguagem (SEAL), tem como base a teoria enunciativa e seu diálogo com a psicanálise se faz intensamente presente, pois considera o sujeito a partir de sua constituição na enunciação por meio de marcas inscritas em seu discurso; daí um importante elo de discussão entre o campo da Linguística e o da Psicanálise, trazida aqui pelo arcabouço de Winnicott. O autor traz os conceitos de handling e holding para falar da interação entre mãe-bebê como aquilo que escapa à língua, onde o cuidado materno se manifesta pelo toque, ritmo, intensidade, cheiro e olhar; além da hipótese de Preocupação Materna primária e a teoria de Amadurecimento Pessoal, que referem significativamente sobre a importância da ligação entre corpo do bebê e linguagem materna e a necessidade de sincronismo da relação para que haja um desenvolvimento satisfatório da criança.

Em se tratando de linguagem, há uma diferenciação nos termos de domínio gramatical e apropriação da linguagem como a atualização do sistema linguístico no ato enunciativo, na qual a aquisição de linguagem não é abordada somente pelo conhecimento gramatical da língua, mas em sua dimensão discursiva, onde é valorizada a maneira como o indivíduo se coloca no processo discursivo. Dentro desta perspectiva, a aquisição de linguagem se dá na relação $e u$-tu, no vínculo que criança faz com seus interlocutores, a partir de um lugar que igualmente se estabelece para ela e se faz o uso do sistema linguístico. O uso da língua pela criança é sempre único, cabendo considerar o processo de aquisição em um espaço singular, implicando a relação da criança com o "outro" e com a língua, em cada ato de enunciação. O $e u$ e o tu são compreendidos como instancias de funcionamento linguístico-discursivo, havendo produção de sentidos e referências, sendo que a aquisição surge na maneira como cada locutor se apropria da língua e coloca o alocutário no momento da enunciação, dentro de uma posterior apropriação, sob a construção de novos sentidos a partir dos pré-existentes (Silva, 2007).

Para Benveniste a língua é sempre uma mediação entre os indivíduos, cultura e sociedade, valorizando-se os aspectos intersubjetivos da comunicação, que abarca estas três instâncias citadas simultâneas em seu funcionamento. Para tal, a criança ocupa uma relação intersubjetiva junto à mãe; "a criança nasce e desenvolve-se na sociedade dos homens. São homens adultos, seus pais, que lhe inculcam o uso da palavra" (Benveniste, 1995, p. 31). É pela via da intersubjetividade que a comunicação linguística se dá, pois para o autor em questão é sempre a partir do ato da fala dentro de uma troca com o outro que a experiência da linguagem se coloca. 
A protoconversação entre mãe e bebê se mostra enquanto origem no diálogo eu-tu, sendo preenchido com vocalizações, balbucio, diálogo tônico-postural, olhar, entre outros, constituindose de valor ímpar na construção subjetiva do bebê. Daí a importância do tema central desta pesquisa sobre tais aspectos em uma população que se mostra de risco, como a dos irmãos de crianças com TEA, ainda pouco olhada pelos profissionais de saúde. O processo de aquisição de linguagem se apresenta intrinsicamente ligado às relações iniciais mãe-bebês, sendo que interações deficientes podem propiciar instalação de distúrbios de linguagem ou transtornos de desenvolvimento futuros. Flores, Beltrami e Ramos (2011) observaram nas sessões de terapias com bebês e crianças pequenas que mães de bebês em situações de risco, diferentemente daquelas que não possuem o filho nesta condição, parecem não conseguir estar disponíveis na identificação daquilo que é necessário para seus bebês, em cada momento, o que pode dificultar a apropriação de signos pela criança.

Crestani e seu grupo (2016) validaram o instrumento SEAL (Sinais Enunciativo de Aquisição de Linguagem) com o propósito de tanto sinalizar as condições de enunciação oferecidas pelo adulto cuidador (consideradas importantes para que a subjetivação do bebê aconteça no campo da aquisição de linguagem, como captar o funcionamento da linguagem infantil na protoconversação entre o bebê e aquele que exerce a função materna, capaz de predizer possíveis impedimentos na constituição linguística dos bebês.

$\mathrm{O}$ uso do SEAL nesta pesquisa, conjuntamente aos Indicadores de Risco ao Desenvolvimento Infantil (IRDI), a ADBB e informações socioeconômicas, é original por nunca ter sido feito antes.

\subsection{VOZ E LINGUAGEM: CONSIDERAÇÕES A PARTIR DE OUTROS AUTORES}

"Há uma voz, uma voz que é a voz de homem como o canto é a voz do grilo ou o zurro é a voz do burro?

E, se existe, essa voz é linguagem? Qual é a relação entre voz e linguagem, entre phoné e logos? E se algo como uma voz humana não existe, em que sentido pode o homem ser ainda definido 
como o ser vivo que possui linguagem?

As questões assim formuladas delimitam uma interrogação filosófica"

(Agamben, 2007)

Partindo da ópera, Rosolato (1977) refere-se à voz como possibilidade humana, capaz de atingir o mundo que nos cerca. A questão da voz e suas formas de relação com o outro são objeto de infinitas reflexões em todos os campos do saber, já que é algo constituinte do humano e tem origem na mais tenra idade do existir.

No bebê, Rosolato afirma que o grito representa uma manifestação de excitação, seja ela de dor ou prazer, de maneira ativa ou passiva. Posteriormente, os ruídos vocais se tornam ação no espaço, no qual o bebê controla suas emissões e reproduz por imitação os sons vividos, sendo capaz de utilizar este recurso como forma de suportar as angústias de separação entre eu e o outro. A voz é vista como objeto de pulsão, já que para o autor, além do valor biológico, a voz tem um importante papel na busca de prazer, com a intenção de afetar o outro e o intuito de assegurar o vínculo, pensando igualmente na voz como objeto de afeto e representação da palavra.

A afetividade é expressa por meio das inflexões da voz e mudanças de pitch (sensação de frequência) para onde está direcionada a libido; por meio da voz a sexualidade e a agressividade são transmitidas e, dentre tantos caminhos para se expressar afetos, a voz seria o mais eficaz, já que se configura como porta de entrada para a relação primitiva entre o bebê e o outro. Ogden (1998) afirma que uma das formas de se marcar a existência do humano, seria a partir da criação de uma voz, esta compreendida no sentido de "deixar falar" aquilo que se é, sendo uma experiência manifesta no ato da fala ou escrita, já que esta concepção se relaciona com muitas formas de linguagem, seja ela poética ou analítica, por exemplo.

Anzieu (1994) problematiza a voz como uma possibilidade original de manifestação de angústia do bebê diante de sua total fragilidade e dependência. A voz, inicialmente orgânica, marca o aparecimento do bebê fora do corpo materno e aos poucos a criança vai desenvolvendo consciência do que ocorre através de suas pregas vocais, igualmente daquilo que percebe enquanto sons de seu corpo e das sensações que pode se provocar sobre si mesmo. Há um prazer em experênciar os sons que escuta do meio, passando a utilizar estes ruídos para manifestar seus desejos e aprendendo que seus barulhos convocam a presença materna. A voz surge então como 
aquilo que afirma a separação entre o bebê e a mãe, ao mesmo tempo que é ela quem traz o retorno do objeto amado. De acordo com Anzieu (1994, p. 151) "a voz prolonga a boca, que mama nos limites perceptíveis ao ouvido".

Anzieu, a partir do conceito eu-pele, refere a construção do psiquismo como fundamentada na interação com o meio, em paralelo com a realidade orgânica. O autor parte da consideração de Freud na qual a função psíquica se desenvolve com apoio de uma função corporal, cujo funcionamento se coloca para o plano mental. As diversas funções da pele servem de suporte para o eu-pele se constituir como um envelope psíquico, capaz de distinguir o mundo exterior do interior. É pela experiência corporal, na relação de cuidado entre mãe e bebê, que se constrói um espaço interno pelo bebê. Ainda afirma que “(...) a abertura do mundo psíquico da criança se faz em dois tempos: um primeiro tempo materno, o agente de abertura teria a capacidade de rêverie ${ }^{5}$ da mãe; um segundo tempo paterno, o agente de abertura seria a posição paterna, que vem abrir a simbiose mãe-bebê, garantindo a identidade de cada um. Nem por isto arrancar a criança da mãe, nem romper sua raiz simbiótica - ideia da membrana psíquica” (Anzieu, 1994, p. 44). Com o conceito de eu-pele, Anzieu enfatiza a importância de vários envelopes que se originam na relação com o outro e entre eles, destacam-se os envelopes sonoros.

O sonoro, de acordo com Anzieu, é caracterizado pela ausência de concretude, sendo algo inapreensível, no qual somente a fonte sonora, em alguns casos, é capaz de reparar, modular e fabricar este som. A noção de envelope, estritamente clara de suas delimitações físicas, aqui não se faz presente, já que a experiência sonora beira ao impalpável. Porém se a sensação de envelopamento é colocada, faz pensar sobre uma dimensão tátil, que não indica diretamente a noção do sonoro, em si. Compreender a experiência sonora é caminhar para uma elaboração mental do som, a partir do conceito do eu-pele. Para tal, coloca-se igualmente o conceito de banho sonoro elaborado por Anzieu (1976) que introduz a noção musical, assim interpretada por Lecourt (In Anzieu, 1994), se referindo a uma experiência de leveza, de sinestesia, que caminha pela transferência dos afetos, sendo representadas pelo holding, de Winnicott (1975).

É a partir das trocas entre mãe e bebê que as zonas do banho sonoro vão se diferenciando, a começar, desde os primórdios, pela voz materna, que se considera pela qualidade vocal e por tempos de trocas sonoras, que organizam o espaço e o tempo relacional na interação entre mãe e

\footnotetext{
5 Conceito criado por Bion (1991) que se refere à capacidade materna de utilizar seu "aparelho para pensar" os pensamentos do bebê, nomeando e significando seus estados mentais e sensações em um período em que a crianças ainda não tem capacidade para fazê-lo sozinho.
} 
filho, para que em um outro momento a voz passe a existir por ela mesma, separada da presença visual da mãe, permitindo uma comunicação à distância e mesmo a ausência. Dentro destas trocas sonoras se faz muito presente a memória, sem a qual a experiência de feed-back sonoro não poderia existir (Anzieu, 1976).

Lecourt (In Anzieu, 1994) considera o envelope sonoro sobre dois ângulos: o verbal e o musical. Ela sugere que aquilo que faz com que eles se unam é o material sensorial sonoro e a estrutura grupal da qual eles são parte, além da intensidade desta perfeição que necessita da existência do som. Tanto de uma como de outra parte se implantam níveis de diferenciação e de articulação, sendo que o ângulo verbal, mais linear (no tempo) e univocal (aparente) é colocado para o exterior. O ângulo musical, em espessura, tecida pela voz (tanto no tempo como no espaço) e plurivocal, é mais direcionado para o interior. Ela ainda segue afirmando que os modelos de contato são bem distintos, sendo que um soa, canta, vibra e ressoa, como no banho sonoro, enquanto o outro é articulatório e mais abstrato. Um é "nós" e o outro é "eu", em referência às bases grupais de suas estruturas, um é mais voltado para o grupo interno, coesivo e o outro voltado para o grupo externo e a diferenciação, porém são indissociáveis e complementares (Anzieu, 1994 p. 212).

O envelope sonoro necessita de uma mentalização que assegure a noção de espaço, continuidade e continência. Dentro deste aspecto este nível de mentalização não é influenciado pelos códigos de linguagem verbal e musical, tecidos por diferentes sons e silêncios. Porém são diferenciados dentro do plano sonoro por uma delimitação de zonas dentro deste mesmo espaço que são constituídas por sons conhecidos e reprodutíveis, que podem ser associados ou não de maneira flexível. São caracterizados também por modos diferentes de seleção de sons, sendo que a palavra se assemelha a um som musical, havendo variabilidades destas características sonoras, com mudanças prosódicas marcadas por amplificações de intensidades e acentuações variadas de timbres. Há como compreensão a monofonia da palavra, no qual não há qualquer acompanhamento sendo o inverso da polifonia musical e ao mesmo tempo a integração do silêncio que compõe o plano sonoro, repleto de respirações, pontuações e ritmos variados.

Sobre o silêncio Anzieu expõe " a integração combinada do som e do silêncio, relacionada aos códigos verbais e musicais, constituem uma proteção geralmente eficaz contra a experiência traumática (intrusão, buracos, rupturas, pelo som, lacuna, pelo siêncio) e persecutória” (Anzieu, 1994, p. 2011. Tradução nossa). 
Olhar para a voz a partir do conceito de envelopes psíquicos de D. Anzieu, fazendo um recorte específico para o envelope sonoro, nos traz a magnitude de sua importância para a construção subjetiva do indivíduo, na medida em que retrata seu valor para o investimento relacional, apesar da complexidade desta elaboração mental, já que o sonoro passa pela ausência de concretude. Falar sobre a voz invoca a se tentar compreender sobre o processo de aquisição de linguagem e suas articulações com a teoria enunciativa, que embasa o instrumento utilizado nesta dissertação.

Anzieu faz um caminho diferente de Winnicott, ao criarmos paralelos entre os dois autores. Winnicott compreenderia o envelope sonoro enquanto banho melódico a partir da fala materna, na relação entre mãe e seu bebê. $\mathrm{O}$ envelope sonoro seria visto enquanto processo de integração do self, na capacidade da criança de sentir-se real. Para Anzieu, a função especular da voz materna oferece condições para que a experiência vivida pelo bebê possa adquirir representação psíquica, indo mais ao encontro da estruturação do $\mathrm{Eu}$ do que no estágio do eu-sou, como propõe Winnicott. Apesar destas diferenças, que não implicam em oposições, o olhar de ambos auxilia no estudo e compreensão do universo sonoro e processo de subjetivação, no qual este trabalho se propõe a discorrer. 


\section{CAPÍTULO 4: PESQUISA EMPÍRICA}

Mistério, algo que, penso, mais tempo, menos lugar. Quando o mistério voltar, meu sono esteja tão solto, nem haja susto no mundo que possa me sustentar.

(Estrofe do poema Adminimistério - Paulo Leminski)

\subsection{OBJETIVO}

A parte empírica desta pesquisa tem como objetivo verificar se a condição de possuir um irmão com TEA (38 díades - grupo caso) está associada a maior ausência de sinais enunciativos do processo de aquisição de linguagem em comparação com aquelas crianças que não possuem um irmão com este diagnóstico (42 díades - grupo controle). Além de:

A) Averiguar se crianças que foram sinalizadas pelos instrumentos IRDI (Indicadores de Risco para o Desenvolvimento Infantil) e ADBB (Alarm Distress Baby Scale) também foram aquelas indicadas pelo SEAL (Sinais Enunciativos de Aquisição de Linguagem).

B) Fazer análise qualitativa de 1 vinheta do material filmado de uma díade mãebebê considerada em dificuldade na avaliação pelo SEAL.

\subsection{CARACTERIZAÇÃO DA PESQUISA}

Estudo de Caso-Controle com delineamento de corte transversal.

\subsection{SEUS PARTICIPANTES}

A amostra da presente pesquisa é composta de 80 famílias com bebês de 2 até 12 meses e 29 dias e ao menos um (a) filho (a) mais velho (a), sendo 38 famílias do grupo caso, com pelo menos um filho com diagnóstico de TEA e 42 famílias do grupo controle, sem filhos com 
diagnóstico de TEA. Esta amostra tem origem de um banco de dados maior, composto por 144 famílias com bebês entre 2 e 24 meses, sendo 69 famílias caso e 75 famílias controle. As crianças do grupo caso foram encaminhadas por serviços assistências a pessoas com diagnóstico de TEA e que possuíam um irmão mais novo na família. Fizeram parte do estudo os CAPSi dos municípios de São Paulo e Guarulhos, o Serviço de Psiquiatria do Hospital das Clínicas da Faculdade de Medicina da Universidade de São Paulo, a Faculdade de Fonoaudiologia da Universidade de São Paulo, APAE (Associação de Pais e Amigos dos Excepcionais) de São Carlos, AMA (Associação Amiga do Autista) e GAIADI (Grupo Interdisciplinar de Avaliação e Intervenção em Atrasos no Desenvolvimento Infantil) de Ribeirão Preto. A especificidade do critério de inclusão, que correspondia a famílias com ao menos um filho (a) com diagnóstico de TEA e outro filho (a) com idade entre dois e 24 meses, justifica a alta variabilidade de municípios que compuseram a pesquisa, com o intuito de se obter um tamanho importante de amostra.

Encontraram-se as famílias do grupo controle através das Unidades Básicas de Saúde vinculadas aos municípios participantes da pesquisa, do Hospital Universitário da Universidade de São Paulo, Creches e Pré-Escolas da Universidade de São Paulo e Ribeirão Preto, além de indicações de conhecidos por parte das pesquisadoras. Ambos os grupos foram pareados de acordo com o sexo e idade do bebê, município de residência e escolaridade materna/cuidador referência. Os critérios de exclusão adotados foram o de alguma criança apresentar uma síndrome ou problema congênito grave, capaz de alterar seu desenvolvimento global e a adoção de filhos, tendo em vista o conhecimento da importância da carga genética no diagnóstico de TEA.

Ressalto que utilizo aqui os dados já coletados na pesquisa anteriormente mencionada. Minha amostra parte do recorte de crianças deste banco de dados de até 12 meses e 29 dias, sendo que não tive contato direito com as famílias.

\subsection{INSTRUMENTOS DE AVALIAÇÃO}

\subsubsection{Sinais Enunciativos de Aquisição de Linguagem (SEAL)}

Para o estudo em questão, a fim de se captarem de forma mais sensível dificuldades do processo de aquisição de linguagem em irmãos de crianças com TEA, utilizou-se o SEAL.

O instrumento foi validado em 2015 para crianças de até 12 meses e 30 dias e estudos longitudinais estão sendo elaborados pelo grupo de pesquisa da Universidade Federal de Santa 
Maria, liderado pela prof. Dra. Ana Paula Ramos de Souza. O SEAL tem como proposta uma avaliação contínua de habilidades de linguagem e comunicação desde os primeiros meses de vida, levando em consideração a importância de se realizar intervenções na primeira infância a fim de se trabalhar pela remissão e não cristalização de sintomas, entre tantos outros benefícios já validados mundialmente (UNESCO, 2002). Em seu projeto igualmente se visa “(...) ampliar os olhos dos profissionais da puericultura, e em especial do fonoaudiólogo, para a aquisição e desenvolvimento da linguagem infantil a partir de uma proposta teórica que inclua o bebê e suas relações, ou seja, que coloque o princípio da intersubjetividade como central na análise da linguagem" (Crestani, 2016, p. 18). O instrumento está ancorado no IRDI (Indicadores de Risco ao Desenvolvimento Infantil) - Quadro 2, no qual alguns indicadores foram sensíveis para captar questões relativas à aquisição de linguagem.

Crestani (2012) encontrou resultados de valor preditivo em analogia à aquisição de linguagem nos indicadores do IRDI da faixa etária de 1 a 3 meses e 29 dias; igualmente na subfaixa II, que corresponderia às crianças de 4 a 7 meses e 29 dias e subfaixa IV, de crianças de 12 a 18 meses. Os indicadores da subfaixa III não se mostraram presentes na amostra da pesquisa, que correspondeu a 117 bebês. Itens como o 6 - A criança utiliza sinais diferentes para expressar suas diferentes necessidades e o 7 - a criança reage (sorri, vocaliza) quando a mãe ou outra pessoa está dirigindo-se a ela mostraram-se presentes na amostra, mesmo em bebês que teriam distúrbios de linguagem aos 2 anos de idade. Este resultado motivou as pesquisadoras a estudar mais sobre os índices e elaborar um instrumento que fosse mais sensível e específico para o processo de aquisição de linguagem, baseando-se na teoria enunciativa de que é necessário mais do que sorrir e vocalizar ou reagir ao manhês para que o bebê construa sua intersubjetividade.

O SEAL é composto de doze itens observáveis na interação mãe-bebê desde o nascimento e é proposto a partir de fenômenos enunciativos, que permitem captar na relação adulto-criança as posições ocupadas pelo enunciador e as ferramentas linguísticas utilizadas por ele. Encontramos como foco a relação $e u$-tu (criança-adulto, respectivamente), discorrido brevemente na introdução.

O instrumento passou por validação de conteúdo, processo de fidedignidade com método entre avaliadores, análise fatorial e estudos de concordância com o IRDI, Denver II - Linguagem e variáveis obstétricas e socioeconômicas. No método de Consistência Interna obteve-se Alpha=0,84 para a Fase 1 (crianças de 2 até 6 meses e 29 dias) e alfa=0,74 na Fase 2 ( 7 a 12 meses e 29 dias), demostrando confiabilidade. Os itens 1; 3; 4 e 7 foram os de maior relevância na Fase 1 após 
análise fatorial com rotação Varimax, com cargas fatoriais expressas por ordem de importância: 7 $(0,992) ; 3(0,952) ; 4(0,932)$ e 1(0,906). Na Fase 2, a relevância ficou restrita aos itens $11(0,956)$ e 12(0,959).

Como resultado geral houve maior prevalência de risco nos itens do SEAL em relação ao IRDI, sendo que quando uma criança obteve ausente em algum item do IRDI, obteve também no SEAL, porém a recíproca não é verdadeira, já que ausente no SEAL não implicou ausência de IRDI. Já no estudo de concordância com o Denver II-Linguagem obteve-se de forma genérica indício de risco em maior prevalência nos itens SEAL se comparado aos fracassos no Denver II. Uma especificação mais detalhada de todos os resultados encontra-se na tese de doutorado de Crestani (2016).

Pelas características sui generis de cada faixa etária o instrumento foi dividido, resultando em dois: crianças de 2 a 6 meses e 29 dias e dos 7 aos doze meses e 29 dias, respectivamente. Díades em risco pelo SEAL referem-se àquelas que possuem pelo menos um dos itens 1,3,4,7,11 ou 12 ausentes, avaliados após análise fatorial.

Os índices são apresentados no Quadro 1 a seguir:

Quadro 1. Sinais Enunciativos de Aquisição de Linguagem (Crestani, 2016)

\begin{tabular}{|l|}
\hline \multicolumn{1}{|c|}{ Itens 2 meses a $\mathbf{6}$ meses e 29 dias } \\
\hline $\begin{array}{l}\text { 1. } \\
\text { A criança reage ao manhês, por meio de vocalizações, movimentos corporais ou } \\
\text { olhar. }\end{array}$ \\
\hline 2. $\begin{array}{l}\text { A criança preenche seu lugar na interlocução com sons verbais como vogais e/ou } \\
\text { consoantes. }\end{array}$ \\
\hline 3. $\begin{array}{l}\text { A criança preenche seu lugar na interlocução com sons não verbais de modo } \\
\text { sintonizado ao contexto enunciativo (sorriso, grito, choro, tosse, resmungo). }\end{array}$ \\
\hline 4. A criança preenche seu lugar na interlocução silenciosamente apenas com \\
movimentos corporais e olhares sintonizados ao contexto enunciativo. \\
\hline 5. A criança inicia a conversação ou protoconversação. \\
\hline 6. A criança e a mãe (ou sua substituta) trocam olhares durante a interação. \\
\hline
\end{tabular}


7. A mãe (ou sua substituta) atribui sentido às manifestações verbais e não verbais do bebê, e sustenta essa protoconversação ou conversação, quando o bebê a inicia.

8. A mãe (ou sua substituta) utiliza o manhês falando com a criança de modo sintonizado ao que está acontecendo no contexto e aguardando as respostas do bebê.

\section{Itens 7 meses a 12 meses e 29 dias}

9. A criança preenche seu lugar na interlocução (enunciado) com sons verbais (sílabas com vogais e consoantes variadas - ao menos dois pontos e dois modos articulatórios de consoantes).

10. A criança esboça a produção de protopalavras por espelhamento à fala da mãe (ou substituto).

11. A criança esboça a produção de protopalavras espontaneamente.

12. Quando a mãe (ou substituta) é convocada a enunciar pela criança, a mesma reproduz seu enunciado e aguarda a resposta da criança.

\section{a) Aplicação}

Nesta pesquisa, o SEAL foi aplicado às filmagens das interações livres entre mãe/cuidador e bebê, com duração de 6 a 10 minutos oriundas da pesquisa maior e serviram de material para codificação de outros instrumentos. O SEAL segue o mesmo padrão de aplicação do IRDI, realizado por meio de observação e perguntas. A instrução, no momento da gravação, dada pela pesquisadora ao responsável era a de que se interagisse com o bebê conforme o costume, a partir dos recursos que dispunha no momento. Para as crianças acima de 10 meses ficava à disposição para o uso da díade uma caixa lúdica com brinquedos variados (carrinhos, panelinhas, bonecas, ferramentas, animais selvagens, telefone de brinquedo, etc). Vale notar que em todas as filmagens houve a presença de uma pesquisadora, que fazia a gravação, sem interação direta com a dupla. Os contextos de filmagens variaram, desde ambientes domésticos, até institucionais.

A codificação do SEAL foi realizada por Isabela de Moraes Fattore, fonoaudióloga integrante do Núcleo Interdisciplinar de Detecção e Intervenção Precoce da Universidade Federal de Santa Maria, habilitada a codificar o instrumento. A especialista esteve em estado de cegueira 
frente à condição de risco do bebê (irmão com TEA). Os vídeos foram passados à codificadora via internet, sendo oferecido somente como informação a data de nascimento de cada criança.

\subsubsection{Indicadores de Risco para o Desenvolvimento Infantil (IRDI)}

O IRDI foi resultado da pesquisa Multicêntrica de Indicadores de Risco para o Desenvolvimento Infantil ocorrida entre 2000 e 2008 em diversos estados brasileiros, com financiamento do Ministério da Saúde. Este estudo, realizado por um grupo de especialistas, validou 31 indicadores clínicos de desenvolvimento observados nos primeiros 18 meses de vida do bebê, sendo que dois ou mais indicadores ausentes podem estar associados a problemas de desenvolvimento e a risco psíquico em crianças de 3 anos (Kupfer et al, 2009). Os indicadores estão distribuídos em quatro subfaixas, por idade. O instrumento foi elaborado a partir da articulação de conceitos psicanalíticos com outras áreas do saber, com o intuito de ser utilizado por profissionais da área da saúde que trabalham na atenção primária, estando fundamentado a partir de quatro eixos nos quais se alicerça a subjetividade e os conceitos da psicanálise, que abarcam o desenvolvimento emocional do bebê e a relação entre ele e seus pais.

O eixo Suposição de Sujeito (SS) corresponde a uma antecipação da mãe/ cuidador para com o bebê, supondo que existe um sujeito psíquico já formado ali. Esta antecipação provoca grande júbilo do bebê, já que vem carregada de afeto por meio das palavras. O bebê então responde a esta mãe que o permite existir, propiciando a construção da subjetividade.

O Estabelecimento de Demanda (ED) representa a capacidade da mãe de poder receber expressões como o choro, por exemplo, como uma demanda de seu bebê e que é dirigida a ela. Este reconhecimento e esta formação da demanda estarão posteriormente ligados à atividade de inserção do sujeito na relação com outros indivíduos e também na linguagem.

Enquanto isto, o Alternância presença/ausência (PA) concebe as ações maternas enquanto fundamentais para a construção da simbolização na criança. É a alternância de sua ausência e presença (não só física, mas também simbólica) que propicia o bebê a experienciar a descontinuidade, tanto de satisfação, como da presença da mãe, obrigando a criança a criar um dispositivo subjetivo para a simbolização no período de espera do retorno, ação esta que servirá de base para o desenvolvimento de respostas e demandas futuras deste bebê. 
Já o eixo Função Paterna (FP) tem como o intuito de verificar as consequências da presença de um terceiro na relação mãe-bebê, capaz de introduzir aspectos da cultura, que advém em forma de lei (não). O filho, a partir daí, passa a ser um indivíduo singularizado desta mãe, que não tem o bebê mais como algo para a sua satisfação.

Os eixos brevemente descritos correspondem à relação mãe-bebê, às ações da mãe dirigidas ao filho, bem como às produções infantis originárias desta relação inicial. Dos 31 indicadores da grande pesquisa multicêntrica, 18 indicadores se apresentaram enquanto preditivos de riscos ao desenvolvimento, expostos no Quadro 2; crianças com 2 ou mais indicadores ausentes são consideradas em risco.

No estudo maior foi pedido que a mãe interagisse com o bebê como usualmente o faz, sendo que quando não era possível observar se tal comportamento estava presente, o mesmo foi perguntado à mãe e tanto a resposta materna, quanto a observação da pesquisadora (que passou por treinamento) foram consideradas válidas. Todas as interações foram filmadas.

Propriamente nesta pesquisa serão utilizados os resultados da aplicação do IRDI de todos os bebês de até 12 meses e 29 dias. Vale ressaltar que esta codificação foi feita pelo nosso grupo de pesquisa.

Quadro 2. Indicadores de Risco para o Desenvolvimento Infantil (Kupfer, 2009)

\begin{tabular}{|l|c|}
\hline \multicolumn{1}{|c|}{ O A 4 MESES INCOMPLETOS } & EIXOS \\
\hline 1. Quando a criança chora ou grita, a mãe sabe o que ela quer. & SS/ED \\
\hline 2. A mãe fala com a criança num estilo particularmente dirigido à ela (mamanhês). & SS \\
\hline 3. A criança reage ao mamanhês. & ED \\
\hline 4. A mãe propõe algo à criança e aguarda sua reação. & PA \\
\hline 5. Há trocas de olhares entre a criança e a mãe. & SS/PA \\
\hline 4 A 8 MESES INCOMPLETOS & \\
\hline 6. A criança utiliza sinais diferentes para expressar suas diferentes necessidades. & ED \\
\hline
\end{tabular}




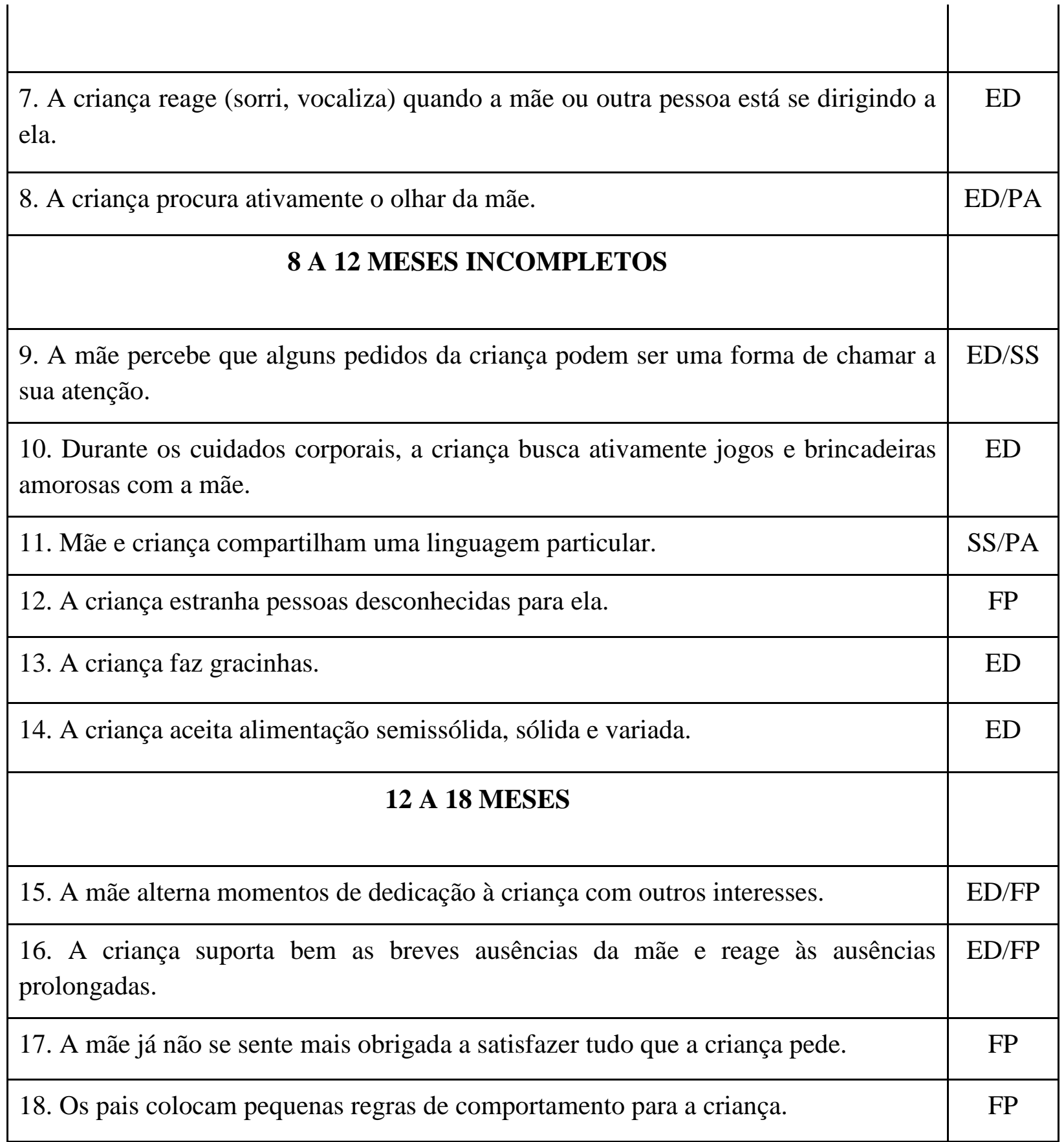

\subsubsection{Escala de Retraimento Prolongado da Criança (ADBB - Alarm Distress Baby Scale)}

Outro instrumento utilizado foi a ADBB, que tem por objetivo avaliar o comportamento de retraimento social de crianças de 2 a 24 meses através da diminuição de reações ao meio pelo bebê, sejam elas positivas (sorriso, contato visual...) ou negativas (choro ou gritos, por exemplo). A 
escala foi criada em 2001 por Guedeney e Fermanian com o intuito de ser aplicada no contexto da consulta pediátrica ou observação psicológica na interação do profissional com o bebê, com validação brasileira (Facuri Lopes et al., 2008).

A escala é composta por oito itens: 1) expressões faciais; 2) contato visual; 3) nível geral de atividade corporal; 4) atividades de auto estimulação; 5) vocalizações; 6) vivacidade na resposta à estimulação; 7) competência para entrar em relação; e 8) competência para se tornar atrativo. Cada um dos itens é cotado numa escala que varia de 0 a 4 , sendo $0=$ absolutamente normal; 1 = dúvida quanto a presença de caráter anormal; $2=$ discretamente, mas nitidamente patológico; $3=$ francamente anormal; e 4 = com caráter patológico severo. Crianças com escore final igual ou superior a 5 seriam aquelas com sinalização de alerta em seu desenvolvimento.

No contexto da pesquisa maior a ADBB foi aplicada através das filmagens das interações livres mãe-bebê, após indicação do Prof. Guedeney em novembro de 2015, em visita ao Brasil.

\subsection{PROCEDIMENTOS}

O projeto maior foi aprovado em 2013 pelo Comitê de Ética e Pesquisa do Instituto de Psicologia da Universidade de São Paulo e pelos serviços de saúde do município de São Paulo, Guarulhos, Ribeirão Preto e São Carlos. Posteriormente as pesquisadoras contataram por telefone as Secretarias de Saúde e a equipe organizou-se com quatro pessoas em São Paulo-Guarulhos e outras duas no interior.

\subsection{AVALIAÇÃO DAS FAMÍLIAS}

Com as famílias selecionadas, assinou-se o TCLE- Termo de Consentimento Livre e Esclarecido, dando início à avaliação com o Questionário 1 (Q1). Este é constituído por dados de parte do perfil dos participantes da pesquisa, sobre o estado emocional daquele cuidador que se apresenta e sobre sua percepção a respeito de suporte social, além de questões sobre o filho (a) mais velho (a). Para tal, foi aplicado o Instrumento CARS - Childhood Autism Rating Scale (Pereira, Riesgo e Wagner, 2008), capaz de diferenciar a partir dos 2 anos de idade crianças com autismo leve-moderado àquelas com autismo grave; Escala de Apoio Social (EAS) que mensura os recursos do meio (relações de suporte interpessoal tais como apoio emocional, afetivo, entre 
outros) que a pessoa julga possuir (Griep et al, 2005); Self-Report Questionnaire (SRQ-20), instrumento criando pela Organização Mundial de Saúde (OMS) que identifica transtornos mentais comuns (TCMs) em adultos (Jesus Mari \& Williams, 1986) e a Escala de Estresse Percebido (PSS 14), capaz de avaliar o grau de estresse em que um indivíduo reconhece nas situações de seu viver.

Em um segundo momento, entrou-se novamente em contato por telefone com esta mesma família a fim de agendar a segunda avaliação, que ocorreu num prazo médio de uma semana da primeira. Para este momento, deu-se preferência para o encontro na residência e a mãe (cuidador/a) era orientada a propor um horário em que o bebê não estivesse com sono, fome ou doente, respeitando a rotina familiar. A aplicação do Questionário 2 (Q2), também com a presença do cuidador de referência e bebê (se prematuro, idade gestacional inferior a 37 semanas, houve correção da idade) contou com o Instrumento M-Chat (Modified Checklist for Autism in Toddlers), que propõe identificar crianças com autismo a partir dos 18 meses de vida (Losapio e Pondé, 2008); a Escala de Retraimento (ADBB) com o estranho, na interação bebê-pesquisador e o IRDI.

Além disto, foi neste momento que houve a filmagem da interação mãe-bebê com vídeos de duração de cinco a dez minutos. É a partir destes vídeos que esta pesquisa se organiza, dado que o SEAL foi codificado através deste banco de imagens em questão. Com a filmagem também foi codificada a escala CIB e a ADBB, igualmente utilizadas neste estudo.

Após aplicação dos Questionários 1 e 2 em todas as famílias realizou-se uma devolutiva para os núcleos familiares frente ao estado de saúde mental dos cuidadores e seus bebês, sendo que os casos detectados com sinal ou sofrimento psíquico, além de riscos ao desenvolvimento foram encaminhados para os serviços de saúde especializados, a fim de que pudessem receber atendimento adequado.

Os dados coletados neste grande projeto, além do trabalho de pós-doutorado da Dra. Julia Durand, foi utilizado na pesquisa de mestrado da Ligia Perez Paschoal, com o título Retraimento social em bebês: um estudo exploratório sobre os irmãos mais novos de crianças com Transtorno do Espectro do Autismo (2016) e está sendo usado pela pesquisadora Stephania A. R. Batista Geraldini para elaboração de sua tese de doutorado igualmente pelo Programa de Pós-graduação em Psicologia Escolar e do Desenvolvimento Humano do IP-USP, todos com orientação do Prof. Dr. Rogerio Lerner.

Este trabalho de mestrado se aterá à amostra com bebês de até 12 meses do banco de dados original. A data de nascimento das crianças aqui selecionadas foi registrada no momento da 
primeira avaliação e fizeram parte da pesquisa as crianças que no momento da filmagem (segunda avaliação) possuíam até 12 meses e 29 dias. Alguns instrumentos citados, como CARS; SRQ-20; PSS 14; M-Chat e CIB não serão utilizados nesta dissertação. A pesquisa se fixará aos resultados da ADBB e IRDI com o intuito de dialogarem e trazerem novos elementos de análise para a pesquisa, a fim de fundamentar melhor os resultados aqui encontrados pelo SEAL, dentro do processo de enunciação na aquisição de linguagem.

\subsection{PREPARAÇÃO PARA ANÁLISE}

Os dados dos questionários 1 e 2 aqui utilizados (idade do bebê, sexo e escolaridade materna) foram devidamente agrupados e tabulados juntamente com a codificação do SEAL, IRDI e ADBB. Utilizou-se o programa Excel 2010 e Stata 20 e o VLC media player para a visualização das filmagens.

\subsection{ANÁLISE DOS DADOS}

As análises descritivas, teste Qui-quadrado Pearson, regressão logística e teste exato de Fisher foram obtidas pelo Excel 2010; software STATA ${ }^{T M} 8.0$ e SPSS. Os resultados terão como base de discussão os autores citados nos capítulos teóricos, dirigidos tanto por autores psicanalíticos, como por nuances teóricas norteadoras do SEAL, além de algumas vinhetas descritivas, a fim de aprofundar os temas desenvolvidos.

\subsection{RESULTADOS}

Os dados aqui apresentados são da totalidade de 80 famílias com crianças de até 12 meses e 29 dias que fazem parte do banco de dados da pesquisa intitulada "Vulnerabilidade de pais $e$ irmãos de crianças com transtorno do espectro autista", sendo 38 delas do grupo caso (bebês irmãos de crianças com TEA) e 42 do controle (bebês irmãos de crianças sem diagnóstico de TEA).

Inicialmente serão expostas as análises entre os grupos caso e controle, que abarcam uma descritiva do SEAL; quantidade de números ausentes em cada díade dos grupos e associação entre os grupos para dificuldade ou não-dificuldade de aquisição de linguagem. As abreviações Ñ-DL 
(Não - Dificuldade de linguagem) e DL (Dificuldade de linguagem) foram escolhidas com o intuito de facilitar a descrição dos resultados para o leitor. Posteriormente se apresentarão as análises entre SEAL com os instrumentos IRDI e ADBB, a partir do teste exato de Fisher e quiqudrado de Pearson, respectivamente. Em seguida, serão expostas as variáveis idade, sexo e escolaridade em relação à DL para o SEAL e, finalmente, a disposição do SEAL sem a divisão de subfaixas.

O teste Qui-quadrado e o teste exato de Fisher foram escolhidos pela necessidade de cruzarmos as variáveis disponíveis na dissertação a fim de observarmos se existem ou não associação entre elas. E optou-se pelo teste de regressão logística visto a característica binária das variáveis.

\subsubsection{O SEAL nos grupos caso e controle}

\section{a) Análise descritiva do SEAL}

A seguir, a Tabela 1 indica o número de díades (N) e sua porcentagem (\%) em cada um dos itens do SEAL pontuados, ou seja, tido como presentes no grupo caso. Do total de 38 díades do grupo caso, 16 delas estão na subfaixa do 7 a 12 meses de idade e, por consequência, pontuam também nos itens 9 a 12. A Tabela 2 descreve este número (N) e sua porcentagem (\%). Observamos na Tabela 1, menor pontuação no item 2- A criança preenche seu lugar na interlocução com sons verbais como vogais elou consoantes, com 39,5\%.

A maior pontuação ficou a cargo do item 4 - A criança preenche seu lugar na interlocução silenciosamente apenas com movimentos corporais e olhares sintonizados ao contexto enunciativo, com 92,10\% de presença; seguido pelos itens 1 - A criança reage ao manhês, por meio de vocalizações, movimentos corporais ou olhar e 6 - A criança e a mãe (ou sua substituta) trocam olhares durante a interação.

$\mathrm{Na}$ Tabela 2, houve pontuação semelhante, de 18,7\% nos itens 9 - A criança preenche seu lugar na interlocução (enunciado) com sons verbais (sílabas com vogais e consoantes variadas ao menos dois pontos e dois modos articulatórios de consoantes); 10 - A criança esboça a produção de protopalavras por espelhamento à fala da mãe (ou substituto) e 11- A criança esboça a produção de protopalavras espontaneamente. 
Tabela 1. Contagem $(\mathrm{N})$ de díades que pontuaram nos itens do SEAL no grupo caso.

\begin{tabular}{lcc}
\hline Itens & \multicolumn{2}{c}{ Grupo caso } \\
SEAL & N & \% \\
\hline Seal1 & 34 & 89,50 \\
Seal2 & 15 & 39,50 \\
Seal3 & 31 & 81,50 \\
Seal4 & 35 & 92,10 \\
Seal5 & 20 & 52,60 \\
Seal6 & 34 & 89,50 \\
Seal7 & 29 & 79,30 \\
Seal8 & 33 & 86,80 \\
\hline Total & 38 & 100 \\
\hline
\end{tabular}

Tabela 2. Contagem (N) de díades que pontuaram nos itens do SEAL do grupo caso na segunda subfaixa de idade.

\begin{tabular}{llc}
\hline Itens & \multicolumn{2}{c}{ Grupo caso } \\
SEAL & N & \% \\
\hline Seal9 & 3 & 18,70 \\
Seal10 & 3 & 18,70 \\
Seal11 & 3 & 18,70 \\
Seal12 & 2 & 12,50 \\
\hline Total & 16 & 100 \\
\hline
\end{tabular}

Já a Tabela 3 refere-se número de díades $(\mathrm{N})$ e sua porcentagem (\%) em cada um dos itens do SEAL pontuados no grupo controle. O item mais pontuado pelas díades, de forma semelhante ao grupo caso, foi o 4 - A criança preenche seu lugar na interlocução silenciosamente apenas com movimentos corporais e olhares sintonizados ao contexto enunciativo, além do item 8 - A mãe (ou sua substituta) utiliza o manhês falando com a criança de modo sintonizado ao que está acontecendo no contexto e aguardando as respostas do bebê, ambos com 92.8\%. Destaque novamente para o item 2 , que segue como o menos pontuado (31\%).

A Tabela 4 refere-se às 24 díades que estão na segunda subfaixa e também pontuam nos itens 9 ao 12, nota-se o item 12 - Quando a mãe (ou substituta) é convocada a enunciar pela criança, a mesma reproduz seu enunciado e aguarda a resposta da criança; como sendo o de menor pontuação, com 4,2\% (somente 1 díade pontuou neste item). 
Tabela 3. Contagem (N) de díades que pontuaram nos itens do SEAL no grupo controle.

\begin{tabular}{lcc}
\hline Itens & \multicolumn{2}{c}{ Grupo controle } \\
& N & \% \\
\hline Seal1 & 37 & 88,10 \\
Seal2 & 13 & 31,00 \\
Seal3 & 38 & 90,50 \\
Seal4 & 39 & 92,80 \\
Seal5 & 20 & 47,60 \\
Seal6 & 40 & 95,20 \\
Seal7 & 32 & 79,20 \\
Seal8 & 39 & 92,80 \\
\hline Total & 42 & 100 \\
\hline
\end{tabular}

Tabela 4. Contagem (N) de díades que pontuaram nos itens do SEAL do grupo controle na segunda subfaixa de idade.

\begin{tabular}{lcc}
\hline Itens & \multicolumn{2}{c}{ Grupo controle } \\
SEAL & N & \% \\
\hline Seal9 & 4 & 16,60 \\
Seal10 & 4 & 16,60 \\
Seal11 & 2 & 8,30 \\
Seal12 & 1 & 4,2 \\
\hline Total & 24 & 100 \\
\hline
\end{tabular}

\section{b) Descritiva da soma do número de ausentes pelo SEAL}

Os dados das Tabelas 5 e 6 referem-se à quantidade de número de ausentes no SEAL entre os grupos caso e controle. O número de ausentes se refere aos itens pontuados negativamente pelas díades (não presentes): quanto maior o número de ausentes, maior a dificuldade no processo enunciativo de aquisição de linguagem (DL) pela criança/mãe.

$\mathrm{Na}$ Tabela 5, que corresponde à primeira subfaixa (2 a 6 meses), 1 díade do grupo caso obteve todos os 8 itens ausentes do SEAL, sendo considerada com grande DL; destaque também para o resultado de 0 ausentes, com 8 duplas do grupo caso e 3 do controle; resultado este inverso ao esperado. 
A Tabela 6, da segunda subfaixa de idade ( 7 a 12 meses), exprime maior homogeneidade entre os grupos caso e controle, realce para a $\mathrm{s}$ duas díades que pontuaram ausente em todos os 12 itens serem do grupo caso.

Tabela 5. Quantidade do número de ausentes no SEAL entre os grupos caso e controle na primeira subfaixa de idade.

\begin{tabular}{lccc}
\hline Idade & $\begin{array}{l}\text { Número } \\
\text { de } \\
\text { ausentes }\end{array}$ & $\begin{array}{c}\text { Caso } \\
(\%)\end{array}$ & $\begin{array}{c}\text { Controle } \\
(\%)\end{array}$ \\
\hline Primeira & $\mathbf{0}$ & $8(36,5)$ & $3(16,6)$ \\
Subfaixa & $\mathbf{1}$ & $3(13,5)$ & $6(33,3)$ \\
& $\mathbf{2}$ & $8(36,5)$ & $7(38,9)$ \\
& $\mathbf{3}$ & $1(4,5)$ & $1(5,6)$ \\
& $\mathbf{4}$ & $1(4,5)$ & 0 \\
& $\mathbf{5}$ & 0 & $1(5,6)$ \\
& $\mathbf{6}$ & 0 & 0 \\
& $\mathbf{7}$ & 0 & 0 \\
& $\mathbf{8}$ & $1(4,5)$ & 0 \\
\hline
\end{tabular}

Tabela 6. Quantidade do número de ausentes no SEAL entre os grupos caso e controle na segunda subfaixa de idade.

\begin{tabular}{cccc}
\hline Idade & $\begin{array}{c}\text { Número } \\
\text { de } \\
\text { ausentes }\end{array}$ & $\begin{array}{c}\text { Caso } \\
(\%)\end{array}$ & $\begin{array}{c}\text { Controle } \\
(\%)\end{array}$ \\
\hline Segunda & $\mathbf{1}$ & 0 & $1(4,3)$ \\
Subfaixa & $\mathbf{2}$ & $1(7,1)$ & $1(4,3)$ \\
& $\mathbf{3}$ & 0 & 0 \\
& $\mathbf{4}$ & $2(14,35)$ & $4(17,45)$ \\
& $\mathbf{5}$ & $3(21,4)$ & $4(17,45)$ \\
& $\mathbf{6}$ & $2(14,35)$ & $6(26,1)$ \\
& $\mathbf{7}$ & $2(14,35)$ & $3(13)$ \\
& $\mathbf{8}$ & $1(7,1)$ & 0 \\
& $\mathbf{9}$ & $1(7,1)$ & $2(8,8)$ \\
& $\mathbf{1 0}$ & 0 & $1(4,3)$ \\
& $\mathbf{1 1}$ & 0 & $1(4,3)$ \\
& $\mathbf{1 2}$ & $2(14,35)$ & 0 \\
\hline
\end{tabular}




\section{c) Associação qui-quadrado (Pearson) para dificuldade ou não-dificuldade de Linguagem}

Os dados seguintes apresentam a distribuição das duplas mãe-bebê segundo cada subfaixa de idade; grupo caso ou controle e que foram classificadas com DL (Dificuldade de Linguagem) ou Ñ-DL (Não-dificuldade de Linguagem) pelo SEAL.

Observamos que os marcadores de significância, indicados na tabela - valor-p - foram superiores a 0,05, número classificatório capaz de indicar a probabilidade de se observar um valor da estatística do teste maior ou igual ao encontrado; significando que o teste qui-quadrado não foi capaz de observar nenhuma associação entre grupo caso (bebês irmãos de crianças com TEA) ou controle (bebês irmão de crianças TEA) e dificuldade de linguagem (DL) ou não dificuldade de linguagem (Ñ-DL) pelo SEAL em nenhuma subfaixa de idade.

Apesar disto, nota-se na Tabela 7 e Gráfico 1, uma tendência na primeira subfaixa a uma dificuldade no processo de aquisição de linguagem (DL) em bebês com irmão com TEA (18,2\%), se comparado aqueles com irmãos sem TEA, pertencentes ao grupo controle $(11,1 \%)$, indicadas por $\tilde{N}$-DL, com variação de 2 bebês para mais no grupo caso (DL).

$\mathrm{Na}$ Tabela 8, observa-se um resultado inverso, com prevalência de bebês de irmãos com TEA no grupo controle $(95,8 \%)$ para DL, comparada aos bebês do grupo caso $(87,5 \%)$. Nota-se elevado número de díades pontuadas com DL na segunda subfaixa, sendo que das 40 díades, apenas 3 não estão com dificuldade neste quesito, sendo 2 do grupo caso e 1 do grupo controle.

Este resultado revela-se extremamente diverso do esperado e fundamentado na literatura entre grupos caso e controle para DL, já que é predito que crianças do grupo caso tenham mais DL do que aquelas do controle. Observa-se também grande disparidade entre a primeira e a segunda subfaixa. Estes aspectos serão aprofundados na seção de discussão.

Tabela 7. Distribuição, na primeira subfaixa, de díades do grupo caso e controle com ou sem dificuldade no processo de aquisição de linguagem.

\begin{tabular}{lcccccc}
\hline $\begin{array}{l}\text { Primeira } \\
\text { subfaixa }\end{array}$ & SEAL & Caso $(\%)$ & $\begin{array}{c}\text { Controle } \\
(\%)\end{array}$ & $\begin{array}{c}\text { Total } \\
(\mathbf{N})\end{array}$ & $\begin{array}{c}\text { Qui } \\
\text { quadrado }\end{array}$ & Valor-p \\
\hline & $\tilde{\mathbf{N}}-\mathbf{D L}$ & $18(81,8)$ & $16(88,9)$ & 34 & & \\
& DL & $4(18,2)$ & $2(11,1)$ & 6 & 0,388 & 0,533 \\
& Total & $22(100)$ & $18(100)$ & 40 & & \\
\hline
\end{tabular}


Tabela 8. Distribuição, na segunda subfaixa, de díades do grupo caso e controle com ou sem dificuldade no processo de aquisição de linguagem.

\begin{tabular}{lcccccc}
\hline $\begin{array}{l}\text { Segunda } \\
\text { subfaixa }\end{array}$ & SEAL & Caso $(\%)$ & $\begin{array}{c}\text { Controle } \\
(\%)\end{array}$ & $\begin{array}{c}\text { Total } \\
(\mathbf{N})\end{array}$ & $\begin{array}{c}\text { Qui } \\
\text { quadrado }\end{array}$ & Valor-p \\
\hline & $\tilde{N}-D L$ & $2(12,5)$ & $1(4,2)$ & 3 & & \\
& DL & $14(87)$ & $23(95,8)$ & 37 & 0,961 & 0,327 \\
& Total & $16(100)$ & $24(100)$ & 40 & & \\
\hline
\end{tabular}

Gráfico 1. Distribuição de díades do grupo caso e controle com (DL) ou sem (Ñ-DL) dificuldade no processo de aquisição de linguagem.

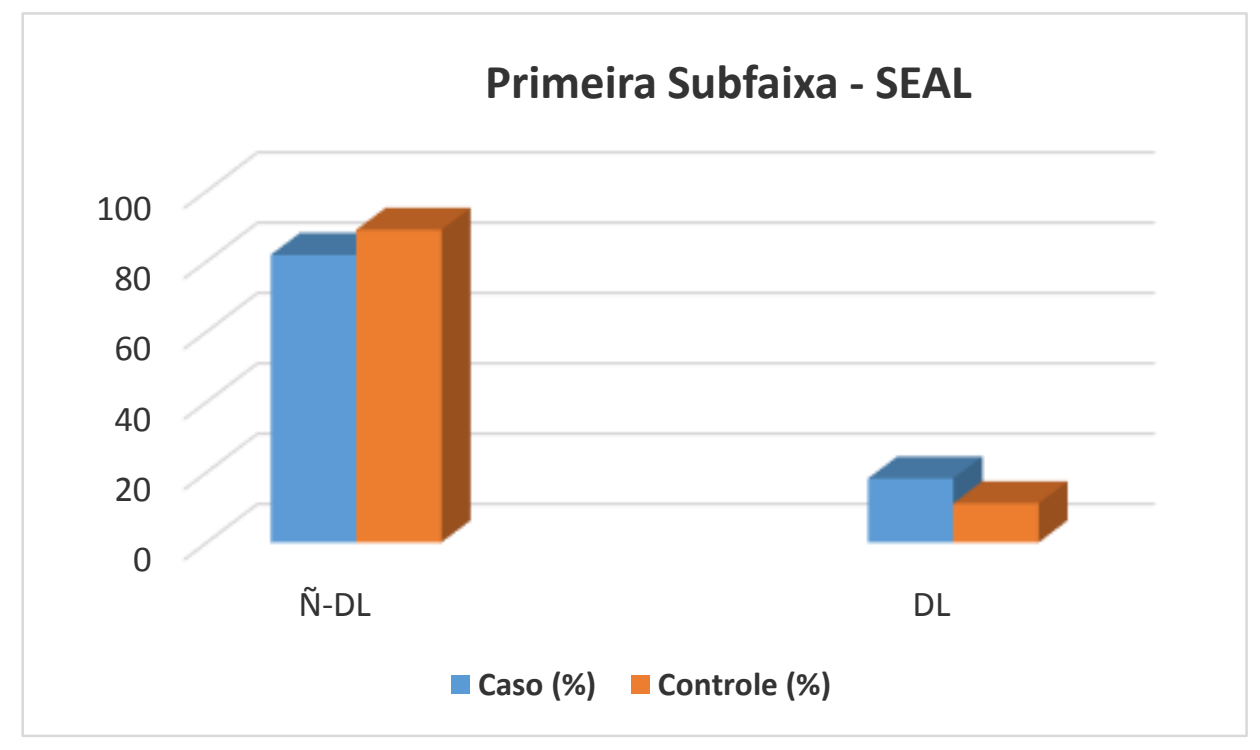


Gráfico 2. Distribuição de díades do grupo caso e controle com (DL) ou sem (N-DL) dificuldade no processo de aquisição de linguagem.

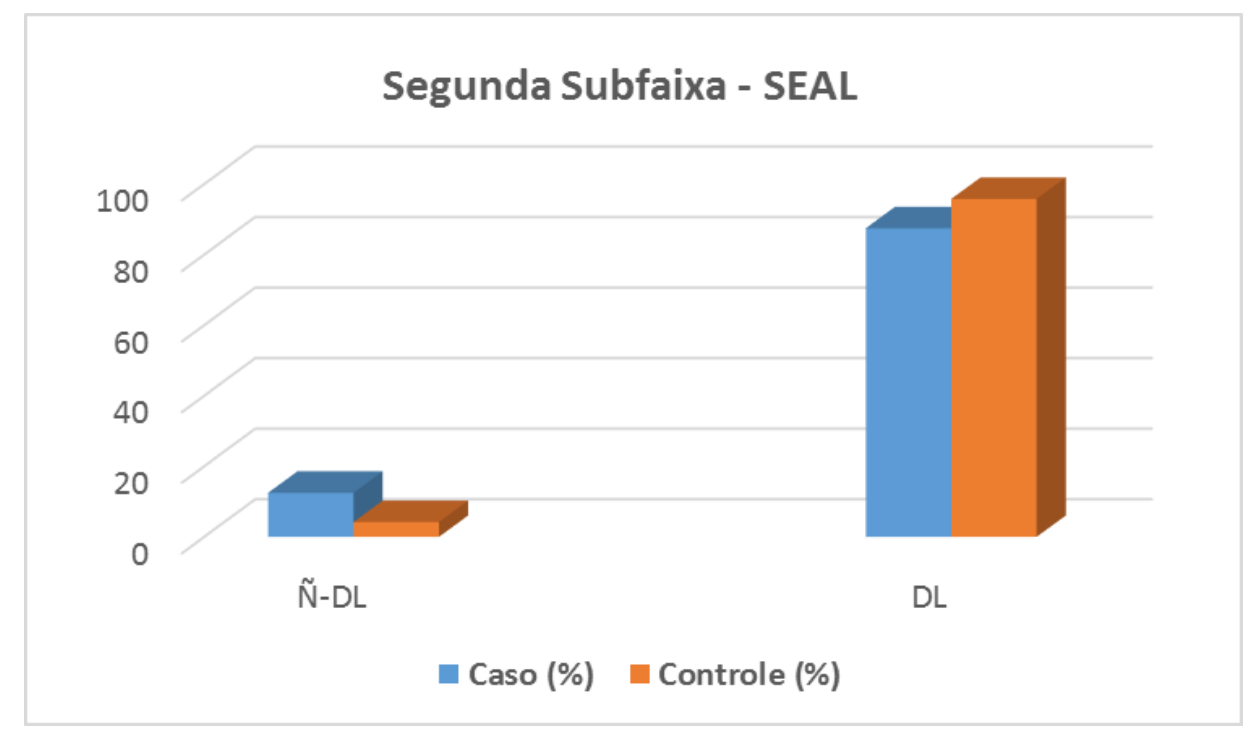

\subsubsection{SEAL e instrumentos}

\section{a) IRDI E SEAL: Análise de Associação pelo Teste Exato de Fisher para Dificuldades de Desenvolvimento (DD) e DL}

Observa-se, na Tabela 9, um valor-p $=0,019$ entre as variáveis DD (Dificuldade de Desenvolvimento) no IRDI e DL (Dificuldade de Linguagem) no SEAL na primeira subfaixa, sendo que das 38 duplas em Ñ-DD pelo IRDI, o total de 34 delas também foram identificadas com N-DL pelo SEAL. Das 6 crianças em DL, 2 delas foram indicadas com DD pelo IRDI.

$\mathrm{Na}$ Tabela 10, na segunda subfaixa, das 33 em Ñ-DD pelo IRDI, 30 foram identificadas com DL pelo SEAL, não havendo dependência entre as variáveis.

Tabela 9. Distribuição, na primeira subfaixa, das díades Ñ-DD e DD avaliadas pelo IRDI em comparação com as díades Ñ-DL e DL avaliadas pelo SEAL.

\begin{tabular}{lcccccc}
\hline $\begin{array}{l}\text { Primeira } \\
\text { subfaixa }\end{array}$ & SEAL & \multicolumn{2}{c}{ IRDI } & $\begin{array}{c}\text { Total } \\
\text { (N) }\end{array}$ & $\begin{array}{c}\text { Qui } \\
\text { quadrado }\end{array}$ & Valor-p \\
\hline & & $\tilde{\mathbf{N}}-\mathrm{DD}(\%)$ & $\mathbf{D D}(\%)$ & & & \\
\cline { 3 - 5 } & $\tilde{\mathbf{N}}-\mathrm{DL}$ & $34(89,5)$ & 0 & 34 & & \\
& DL & $4(10,5)$ & $2(100)$ & 6 & 11,93 & 0,019 \\
& Total & $38(100)$ & $2(100)$ & 40 & & \\
\hline
\end{tabular}


Tabela 10. Distribuição, na segunda subfaixa, das díades Ñ-DD e DD avaliadas pelo IRDI em comparação com as díades Ñ-DL e com DL avaliadas pelo SEAL.

\begin{tabular}{lcccccc}
\hline $\begin{array}{l}\text { Segunda } \\
\text { Subfaixa }\end{array}$ & SEAL & \multicolumn{2}{c}{ IRDI } & $\begin{array}{c}\text { Total } \\
(\mathbf{N})\end{array}$ & $\begin{array}{c}\text { Qui } \\
\text { quadrado }\end{array}$ & Valor-p \\
\hline & & $\tilde{\mathbf{N}}-\mathrm{DD}(\%)$ & DD (\%) & & & \\
\cline { 3 - 4 } & $\tilde{\mathbf{N}}-\mathbf{D L}$ & $3(9,1)$ & 0 & 3 & & \\
& DL & $30(90,9)$ & $7(100)$ & 37 & 0,688 & 1 \\
& Total & $33(100)$ & $7(100)$ & 40 & & \\
\hline
\end{tabular}

b) ADBB e SEAL: Análise de Associação pelo Teste Qui-quadrado Pearson para Retraimento (R) na ADBB e DL pelo SEAL

Houve um valor-p=0,003 entre retraimento $(\mathrm{R})$ pela $A D B B$ e dificuldade de linguagem (DL) pelo SEAL na primeira subfaixa (2 a 6 meses de idade), sendo que das 35 crianças sem retraimento (SR) pela ADBB, 32 delas não foram identificadas em dificuldades de linguagem ( $\tilde{\mathrm{N}}$ DL) pelo SEAL. Por outra perspectiva, 3 do total de 6 crianças em DL pelo SEAL, também foram avaliadas em Retraimento pela ADBB, com chance de 50\% de associação entre DL e R.

A segunda subfaixa, observada na Tabela 12, não indica significância entre os instrumentos, sendo que das 37 crianças com dificuldades de linguagem (DL) pelo SEAL, 7 delas foram identificadas como retraídas pela $\mathrm{ADBB}$.

Tabela 11. Distribuição, na primeira subfaixa, das díades SR e R avaliadas pela ADBB em comparação com as díades N-DL e DL avaliadas pelo SEAL.

\begin{tabular}{lcccccc}
\hline $\begin{array}{l}\text { Primeira } \\
\text { Subfaixa }\end{array}$ & SEAL & \multicolumn{2}{c}{ ADBB } & $\begin{array}{c}\text { Total } \\
\text { (N) }\end{array}$ & $\begin{array}{c}\text { Qui } \\
\text { quadrado }\end{array}$ & Valor-p \\
\hline & & SR $(\%)$ & $\mathbf{R}(\%)$ & & & \\
\cline { 3 - 5 } & N-DL & $32(91,4)$ & $2(40)$ & 34 & & \\
& DL & $3(8,6)$ & $3(60)$ & 6 & 9,076 & 0,003 \\
& Total & $35(100)$ & $5(100)$ & 40 & & \\
\hline
\end{tabular}


Tabela 12. Distribuição, na segunda subfaixa, das díades SR e R avaliadas pela ADBB em comparação com as díades Ñ-DL e DL avaliadas pelo SEAL.

\begin{tabular}{|c|c|c|c|c|c|c|}
\hline \multirow[t]{2}{*}{$\begin{array}{l}\text { Segunda } \\
\text { subfaixa }\end{array}$} & \multirow[t]{2}{*}{ SEAL } & \multicolumn{2}{|c|}{ ADBB } & \multirow[t]{2}{*}{$\begin{array}{c}\text { Total } \\
(\mathrm{N})\end{array}$} & \multirow[t]{2}{*}{$\begin{array}{c}\text { Qui } \\
\text { quadrado }\end{array}$} & \multirow[t]{2}{*}{ Valor-p } \\
\hline & & SR $(\%)$ & $\mathrm{R}(\%)$ & & & \\
\hline & $\tilde{\mathbf{N}}$-DL & $2(6,3)$ & $1(12,5)$ & 3 & & \\
\hline & DL & $30(93,7)$ & $7(87,5)$ & 37 & 0,36 & 0,548 \\
\hline & Total & $32(100)$ & $8(100)$ & 40 & & \\
\hline
\end{tabular}

\subsubsection{O SEAL e outros fatores}

a) Fator Idade e DL pelo SEAL: Análise de Associação pelo Teste Quiquadrado Pearson

A análise indica haver uma forte associação entre a idade e dificuldade de aquisição de linguagem (DL) pelo Seal, com valor-p menor que 0,0001, conforme a tabela 14 demonstra, indicando que díades da segunda subfaixa apresentar maiores índices de DL do que crianças na primeira subfaixa.

Na segunda subfaixa, 86\% (N=37) das duplas foram indicadas com DL pelo SEAL, em contraponto à primeira subfaixa, com frequência de $14 \%(\mathrm{~N}=6)$ com DL. Para as díades Ñ-DL, $91,9 \%$ encontra-se na primeira subfaixa e $8,1 \%$ na segunda subfaixa, somente.

Tabela 13. Associação de DL pelo SEAL nas diferentes subfaixas de idade

\begin{tabular}{cccccc}
\hline \multicolumn{7}{c}{ SEAL } & & & \\
& $\tilde{N}-D L(\%)$ & DL $(\%)$ & Total & qui quadrado & valor-p \\
\hline $\mathbf{2}$ a 6 meses & $34(91,9)$ & $6(14)$ & 40 & & \\
$\mathbf{7}$ a 12 meses & $3(8,1)$ & $37(86)$ & 40 & 48,322 & $<0,0001$ \\
Total & $37(100)$ & $43(100)$ & 80 & & \\
\hline
\end{tabular}




\section{b) Sexo, escolaridade materna e DL para o SEAL: Análise de Associação pelo Teste Qui-quadrado Pearson}

Como pode ser visto na Tabela 14, parece haver uma tendência, na primeira subfaixa, a meninas possuírem menos DL do que os meninos: 21 meninas não apresentaram DL versus 13 meninos. Já na segunda subfaixa, este resultado não se dá, havendo uma maior proporcionalidade entre os gêneros.

Na Tabela 15 o fator Escolaridade materna foi dividido em 6 categorias, sendo a categoria 1 correspondente ao ensino fundamental incompleto; 2 ao fundamental completo; $\mathbf{3}$ ao ensino médio incompleto; $\mathbf{4}$ ao médio completo; $\mathbf{5}$ ao superior incompleto; $\mathbf{6}$ a superior completo.

Na primeira subfaixa, o número de mães com ensino médio completo predomina, sendo que das 17 díades, 4 delas encontram-se com DL. Nesta subfaixa, não houve mães com ensino superior incompleto. Na segunda subfaixa, a categoria 4 - ensino médio completo também prevalece, com 15 mães, sendo que deste total, 13 delas foram indicadas pelo SEAL, junto aos seus filhos, com DL.

Tabela 14. Variação de gênero masculino e feminino, nas duas subfaixas de idade, com o fator DL e Ñ-DL no processo de aquisição de linguagem pelo SEAL.

\begin{tabular}{ccrr}
\hline Idade & Sexo & \multicolumn{1}{c}{$\begin{array}{c}\tilde{N}-D L \\
(\%)\end{array}$} & \multicolumn{1}{c}{$\begin{array}{c}\text { DL } \\
(\%)\end{array}$} \\
\hline 2 a 6 & Masculino & $13(35,1)$ & $3(7)$ \\
meses & Feminino & $21(56,8)$ & $3(7)$ \\
7 a 12 & Masculino & $3(8,1)$ & $19(44)$ \\
meses & Feminino & 0 & $18(42)$ \\
\hline
\end{tabular}


Tabela 15. Variação de categorias de escolaridade, nas duas subfaixas de idade, com o fator DL e Ñ-DL no processo de aquisição de linguagem pelo SEAL.

\begin{tabular}{cccc}
\hline Idade & Escolaridade & $\begin{array}{c}\tilde{\mathbf{N}}-\mathrm{DL} \\
(\boldsymbol{\%})\end{array}$ & $\begin{array}{c}\text { DL } \\
(\boldsymbol{\%})\end{array}$ \\
\hline $\begin{array}{c}\mathbf{2} \text { a 6 } \\
\text { meses }\end{array}$ & $\mathbf{1}$ & $2(5,9)$ & 0 \\
& $\mathbf{2}$ & $4(11,8)$ & 0 \\
& $\mathbf{3}$ & $7(20,6)$ & $1(16,7)$ \\
& $\mathbf{4}$ & $13(38,2)$ & $4(66,6)$ \\
& $\mathbf{5}$ & 0 & 0 \\
& $\mathbf{6}$ & $8(23,5)$ & $1(16,7)$ \\
\hline 7 a 12 & $\mathbf{1}$ & 0 & $7(18,9)$ \\
meses & $\mathbf{2}$ & 0 & $2(5,4)$ \\
& $\mathbf{3}$ & 0 & $8(21,6)$ \\
& $\mathbf{4}$ & $2(66,7)$ & $13(35,2)$ \\
& $\mathbf{5}$ & 0 & $2(5,4)$ \\
& $\mathbf{6}$ & $1(33,3)$ & $5(13,5)$ \\
\hline
\end{tabular}

\section{c) Teste de regressão logística sobre os fatores}

Visando a uma identificação de potenciais efeitos, foi realizada uma regressão logística, tendo a DL como desfecho e a escolaridade e sexo como preditores. Como há muitos valores “zero" na escolaridade, elas foram agrupadas em apenas 3 categorias: fundamental (2), médio [2(1)] e superior [2(2)].

A tabela abaixo indica os valores-p associados às variáveis investigadas. Como pode ser visto, nenhuma das variáveis ou seus níveis parecem ter efeito sobre a DL (dificuldade de linguagem) ou Ñ-DL (não dificuldade de linguagem) do SEAL, nem mesmo as idades da primeira e segunda subfaixas 
Tabela 16. Regressão Logística sobre as variáveis sexo e escolaridade sobre DL pelo SEAL

\begin{tabular}{|c|c|c|c|c|}
\hline \multicolumn{5}{|c|}{ Variáveis na equação } \\
\hline Idade & & Wald & $\begin{array}{c}\text { Grau } \\
\text { liberdade }\end{array}$ & Valor-p \\
\hline \multirow{4}{*}{2 a 6} & $\begin{array}{l}\text { escolaridade } \\
2\end{array}$ & 0,314 & 2 & 0,855 \\
\hline & $\begin{array}{l}\text { escolaridade } \\
2(1)\end{array}$ & 0 & 1 & 0,999 \\
\hline & $\begin{array}{l}\text { escolaridade } \\
2(2)\end{array}$ & 0 & 1 & 0,999 \\
\hline & Sexo & 0,059 & 1 & 0,808 \\
\hline \multirow{4}{*}{6 a 12} & $\begin{array}{l}\text { escolaridade } \\
2\end{array}$ & 0,004 & 2 & 0,998 \\
\hline & $\begin{array}{l}\text { escolaridade } \\
2(1)\end{array}$ & 0 & 1 & 0,999 \\
\hline & $\begin{array}{l}\text { escolaridade } \\
2(2)\end{array}$ & 0 & 1 & 0,999 \\
\hline & Sexo & 0 & 1 & 0,998 \\
\hline
\end{tabular}

\subsubsection{O SEAL sem a divisão de subfaixas de idade}

O objetivo desta análise foi buscar uma potencial relação entre as variáveis caso e controle junto à DL pelo SEAL, independentemente da idade. Como eram variáveis dicotômicas, optou-se pela utilização do teste qui quadrado.

A tabela 17 indica que as proporções de Seal são bastante semelhantes nos dois grupos, ficando sempre entre 40 e $60 \%$. De fato, o teste realizado não mostrou uma dependência entre as duas variáveis ( $\chi^{2}=1,186$ e $\mathrm{p}=0,276$ ), indicando que mesmo com um possível aumento da amostra $(\mathrm{N}=80)$ os resultados não seriam diferentes dos encontrados.

Tabela 17. Análise DL e N-DL sem divisão das subfaixas de idade

\begin{tabular}{cccc}
\hline & \multicolumn{2}{c}{ SEAL } & \\
& DL (\%) & $\begin{array}{c}\text { N-DL } \\
(\%)\end{array}$ & Total \\
\hline Caso & $20(52,6)$ & $18(47,4)$ & 38 \\
Controle & $17(40,5)$ & $25(59,5)$ & 42 \\
Total & $37(46,2)$ & $43(53,8)$ & 80 \\
\hline
\end{tabular}




\subsection{DISCUSSÃO}

Os resultados revelam não haver diferenças significativamente estatísticas entre os grupos caso e controle no quesito de sinais enunciativos de aquisição de linguagem avaliado através do instrumento SEAL, tanto para a primeira subfaixa, de 2 a 6 meses e 29 dias, como para a segunda subfaixa, de 7 a 12 meses e 29 dias. Porém observa-se uma tendência, na primeira subfaixa, a uma maior dificuldade no processo de aquisição de linguagem no grupo caso (irmãos mais novos de crianças com TEA), se comparada ao grupo controle (irmãos de crianças sem o diagnóstico de TEA), com ligeira variação de 7,1\% a mais para díades do grupo caso com dificuldades de linguagem em comparação com aquelas do grupo controle.

Ainda nesta primeira subfaixa, houve consonância entre os instrumentos SEAL, IRDI e ADBB: díades com não dificuldades no processo de aquisição de linguagem também foram assinaladas com não dificuldades de desenvolvimento (p-valor=0,019) e sem retraimento infantil (p-valor=0,003) pelos instrumentos indicados, sucessivamente. Percebemos que as duplas com DL e DD ou com DL e R, apesar do valor-p ter sido baixo, não se associam tão intensamente como as do $\tilde{N}-D L$ e Ñ-DD ou Ñ-DL e SR.

Mesmo assim, tais achados vão ao encontro da literatura apresentada no capítulo 2, na qual os irmãos mais novos de crianças com autismo podem apresentar maiores entraves de desenvolvimento se comparados às crianças que não possuem um irmão com diagnóstico de TEA. Como já referido, atrasos motores estão intimamente ligados a retrocesso no desenvolvimento da linguagem e atrasos de linguagem puderam ser mensurados nestes irmãos de crianças com TEA no primeiro e segundo ano de vida. Para os primeiros meses de vida da criança, Ramos (2013) expressa a importância dos aspectos corporais (não verbais) do bebê juntamente com o sistema verbal materno, indicando que mães de bebês em situações de dificuldades de desenvolvimento parecem não estar tão sensíveis para captar as sutilezas nas demandas não verbais (corporais) de seu filho, como já exposto brevemente no capítulo 3.

Ao analisarmos os aspectos de desenvolvimento e aquisição linguagem a partir do prisma da multicausalidade, que infere que o ambiente familiar é um fator importante para o desenvolvimento global-linguístico, levantamos a hipótese desta influência sobre os achados, pensando nas especificidades de nossa amostra, partindo de um universo balanceado. 
Cachapuz (2006) identifica fatores de risco para o quesito estudado em famílias com baixo nível de instrução dos pais e baixo nível socioeconômico, além de uso de drogas pelos pais, pobreza, baixa escolaridade materna e abuso infantil ou negligência. Pelo teste qui-quadrado de Pearson e de regressão logística observou-se o fator de escolaridade da mãe com o intuito analisar esta variável significativa, capaz de influenciar os resultados. Este dado encontrava-se dentro do questionário da grande pesquisa; a informação socioeconômica da família foi excluída pelo elevado número de repostas ausentes na amostra, além de que usualmente o dado de escolaridade e renda familiar são condicionantes. Não foi observado nenhum efeito da variável escolaridade materna para dificuldade de aquisição de linguagem pelo SEAL, expressando a não existência de parcialidade quanto à escolaridade na amostra.

Um dos fatores de proteção às adversidades do ambiente em que as crianças vivem é o apoio social, com cuidadores afetivos e atentos às demandas infantis. Uma criança bem inserida em um contexto familiar afetuoso e unido tende a lidar com as situações de adversidade de forma mais eficaz do que crianças sem tais apoios (Cachapuz, 2006). É desta forma que indica Winnicott, por meio dos conceitos de handling e holding, que visam a necessidade da construção de um ambiente sustentador e integrativo como via saudável de desenvolvimento psíquico do bebê. Discorrendo mais sobre este ambiente suportivo, o autor em questão também enfatiza a importância da mutualidade entre os locutores, que resulta das identificações cruzadas e a precisão, para além das satisfações fisiológicas, que é primordial ao bebê: um espaço acolhedor. Se apropriar da realidade, para o autor, significa entrar na linguagem. E esta realidade deve vir inicialmente da mãe, capaz de se adaptar às necessidades do bebê. Apesar de não termos tido a oportunidade de cruzar dados que levem em conta o apoio social, é importante levantarmos na discussão esta variável significativa para compreendermos melhor nossos resultados.

Paschoal (2016), em sua dissertação que leva o mesmo banco de dados aqui utilizado, não encontrou relação em apoio social percebido pela mãe, medido pela Escala de Apoio Social (EAS) e presença de retraimento social do bebê. Soube posteriormente, através de estudo de colega que faz uma análise qualitativa de alguns casos clínicos deste banco de dados, que muitas das mães, só puderam falar de suas angústias e sentimentos de abandonos em um outro espaço, no qual um vínculo mais duradouro foi estabelecido, onde a escala, no momento da aplicação, não foi capaz de mensurar. 
Flax et al (2003) afirmam que o sexo masculino apresenta um desenvolvimento mais lento, estando desta forma mais suscetível a problemas de linguagem, se comparada às meninas, que apresentam menos alterações linguísticas. A literatura aponta igualmente maior incidência de TEA entre indivíduos do sexo masculino na proporção de 4:1 (Araujo, 2013). Nesta pesquisa o sexo da criança pareceu também não influenciar sobre a nossa questão, apesar de haver leve tendência na primeira subfaixa para o sexo feminino a Ñ-DL. Além disto, resultados de Paschoal (2016) encontraram que o retraimento dos bebês do grupo caso não respondiam ao sexo deles próprios, mas existia uma correlação com o sexo do irmão mais velho, com diagnóstico de autismo, havendo uma chance de retraimento destes bebês, se o irmão com TEA fosse menino. Diferentemente das crianças do grupo controle, na qual o sexo deles próprios exerceriam mais influência. Pesquisas futuras, que abarquem o sexo do irmão mais velho e a questão de sinais de aquisição de linguagem, se fazem necessárias na tentativa de compreendermos as influencias intricadas nos processos de desenvolvimento linguístico no universo desta pesquisa, especificamente.

Ao analisarmos o fator idade, observamos grande aumento da dificuldade de aquisição de linguagem pelo SEAL na segunda subfaixa, que corresponde às crianças de 7 meses a 12 meses incompletos. Na medida em que as crianças se desenvolvem, são esperadas e exigidas novas competências, o que justificaria a avaliação de mais itens em relação às crianças mais novas, porém para compreendermos melhor este resultado é importante voltarmos um pouco às etapas de desenvolvimento infantil, a fim de observarmos aquilo que é esperado em cada faixa de idade.

Sabe-se que o desenvolvimento linguístico ocorre paralelamente aos desenvolvimentos neuromotor, psicoafetivo e o cognitivo e que o período mais intenso de aquisição de linguagem acontece nos três primeiros anos de vida, tempo de grande ampliação e maturação cerebral. De acordo com a literatura, a linguagem pode ser vista sobre a dicotomia tradicional de Compreensão e Produção; Compreensão Auditiva e Produção Oral, apesar de alguns autores descreverem até os 12 meses de idade, como um período pré-linguístico (Sim-Sim, 1998); (Rigolet, 1998).

O processo de desenvolvimento da produção de sons, de acordo com Sim-Sim; Silva \& Nunes (2008), é regido pela maturação biológica, revelando uma universalidade neste aspecto, levando em consideração, é claro, a integridade fisiológica de cada um. Para cada etapa do desenvolvimento são esperadas novas competências: o bebê ao nascer é capaz de maneira inata de reagir a variações acústicas relacionadas a voz humana, sendo esperado, de 0 a 6 meses, na área de Produção Oral, um choro diferenciado em contextos variados e a produção de sons, seja em 
interação ou sozinho. Para crianças de 6 a 12 meses, é confiado que se utilizem de sons para chamar a atenção, balbuciem repetidamente, se comuniquem através de expressões faciais e que digam uma ou duas palavras (não; pai; mãe; ...) (Rebelo \& Vital, 2006).

$\mathrm{Na}$ área de Compreensão Auditiva, é esperado do 0 aos 6 meses que a criança reaja a sons e dirija seu olhar/rosto para a origem destes sons e, dos 6 aos 12 meses, que se responda ao nome; identifique alguns objetos comuns; compreenda ordens simples (dá, diz tchau, não, ...) e que se mobilize com sons/música (Rebelo \& Vital, 2006). Percebe-se logo que o SEAL está de acordo com as teorias de desenvolvimento que marcam domínios importantes de aquisição em cada faixa de idade, sendo coerente a divisão por subfaixas utilizada e as aquisições exigidas pelo instrumento, de acordo com a literatura da área.

Na pesquisa de Paschoal (2016), que utilizou o mesmo banco de dados desta dissertação, foi encontrada uma concentração de bebês com retraimento, mensurados pela ADBB, no segundo semestre do primeiro ano (entre 7 e 12 meses) que corresponderam a $42 \%$ de toda amostra (8 dos 19 bebês). Este resultado parece indicar que esta subfaixa possui maior vulnerabilidade se comparada a outras idades. Apesar de não haver significância entre SEAL e ADBB para a subfaixa de 7 a 12 meses em nossa amostra, das 8 crianças identificadas com retraimento pela ADBB, 7 foram sinalizadas com DL pelo SEAL. O teste não deu associação, pois a maioria das duplas com DL pelo SEAL não foram avaliadas com retraimento pela ADBB. Porém como estamos levantando a hipótese de possíveis vieses metodológicos influenciando neste resultado, é importante ressaltar este achado, independentemente de decorrência.

É neste período de idade que o bebê, após os períodos de integração do ego, inicia o processo de diferenciação entre a psique e a soma, dando conta da sua existência, sendo capaz de poder se ver habitado em seu próprio corpo (Winnicott, 1990). O bebê, com experiências de handlings positivas, desenvolve vivencias de continuidade que vão sendo fortificadas e dando capacidade à criança de diferenciar a realidade externa de seu esquema corporal. Para que esta vivência aconteça é necessário uma ritmicidade nos encontros, supondo que relações menos recíprocas entre mães e bebês, possam vir a alterar o processo de subjetivação.

Podemos também observar entre 8 e 12 meses de idade a ansiedade dos oito meses, descrita por Bowlby (1990) e Spitz \& da Rocha (1998), que refere o choro do bebê após afastamento da mãe ou aproximações de estranhos. Este comportamento pode ter se expressado nos encontros filmados, pela presença da pesquisadora, e impedido que muitas nuances fossem captadas, o que 
justificaria o grande número de itens ausentes no SEAL. Além disto, pode-se refletir se o SEAL estaria vulnerável a um viés decorrente desta característica típica do desenvolvimento infantil, modificando os resultados.

Retornando aos vídeos, observamos que das 40 crianças, 5 expressaram comportamento de choro e desconforto em algum momento da filmagem, ficando nítido certo retraimento dos bebês, que foram pontuadas pelo SEAL. Em um outro vídeo, a mãe se ausenta em grande parte da filmagem para falar ao telefone e a criança fica muito tempo sozinha, com a chupeta na boca. É de refletir se este vídeo poderia ter sido retirado da amostra por não corresponder à insígnia proposta, supondo também que a díade deixou de expressar muitos comportamentos pela falta de interatividade colocada pela mãe, o que não significa que em outras situações, de maior disponibilidade materna, tais aspectos não poderiam aparecer. Se retirássemos estes 6 vídeos da amostra, mesmo assim o resultado seria bastante significativo, se comparado à primeira subfaixa, ao avaliarmos o nível de dificuldade de linguagem identificado pelo SEAL.

Como este trabalho se origina de uma base de dados secundária, os vídeos não foram filmados com a intenção de se captar algumas nuances linguísticas que o SEAL se atenta de maneira mais pormenorizada e que talvez poderiam ser melhor observadas com um direcionamento da pesquisadora para que a mãe se dirigisse verbalmente ao seu bebê ou para que ela incentivasse o bebê a se expressar mais verbalmente. Uma codificação dos vídeos por mais de uma especialista precisa ser levada também em consideração em futuras pesquisas, com o intuito de criar mais fidedignidade para os resultados. Este trabalho não pode executar este fator devido a dificuldades que se expressaram em limitações financeiras, de dispor de mais uma profissional treinada para codificar o instrumento.

A pesquisa "Vulnerabilidade de pais e irmãos de crianças com transtorno do espectro autista" encontrou na CIB uma piora em 5 dos 8 compósitos medidos pelo instrumento na subfaixa de 12 a 24 meses em comparação com a primeira subfaixa, de até 12 meses de idade da criança. Houve agravamento de todos os itens maternos: intrusividade, queda de 0,11 na média; sensibilidade, piora de 0,12 na média e limite, com piora de 0,9 na média. Para a criança houve queda na média do compósito envolvimento, de 0,10 e para a díade, houve piora da reciprocidade 0,16 (Durand et al., Infant Mental Health Journal, no prelo).

Poderíamos levantar a hipótese de que tais resultados vão ao encontro dos nossos achados da segunda subfaixa de idade, onde as crianças apresentaram mais DL ao compararmos com a 
primeira subfaixa, supondo uma possível queda das competências maternas influenciando no processo de apropriação linguísticas das crianças. Porém, esta hipótese não se sustenta ao analisarmos o resultado oposto à literatura em relação ao grupo caso e controle na segunda subfaixa, na qual as díades do grupo controle obtiveram uma frequência maior de dificuldade (62\%) no processo de aquisição de linguagem em comparação com as do grupo caso (38\%). Poderíamos imaginar que isto ocorreu porque as duplas do grupo caso teriam conseguido desenvolver importantes competências em favor de um desenvolvimento linguístico esperado, ao compararmos com os grupos caso da primeira subfaixa. Díades do grupo caso (que seriam mais vulneráveis, de acordo com a literatura) não se mostraram em maiores dificuldades em nossa amostra nesta segunda subfaixa. Poderíamos supor possíveis melhores competências destas mães de crianças com TEA, que não suprimiram seus investimentos aos seus bebês por terem tido um primeiro filho com TEA, conseguindo estabelecer experiências de reciprocidade com seus filhos. Além destes bebês irmãos de crianças com TEA terem conseguido desenvolver a sintonia afetiva necessária para se estabelecerem na linguagem, junto às suas mães. Porém acreditamos que esta hipótese seja pouco possível visto as discrepâncias dos dados em relação à literatura e os vieses metodológicos intricados na pesquisa.

Voltando ao resultado da maior frequência de DL na segunda subfaixa, podemos tecer alguns paralelos com os limites no estabelecimento do diagnóstico de autismo no primeiro ano de vida e na reflexão sobre o processo de aquisição de linguagem trazido pelo SEAL, já que o desenvolvimento linguístico surge concomitantemente a outros desenvolvimentos, como o motor, psíquico e neurológico. Garcia \& Lampreia (2018) expressam as deficiências em se diagnosticar crianças com autismo no primeiro ano de vida, na medida em que os sinais do transtorno podem mudar consideravelmente com a idade, sendo mais sutis nos primeiros meses e mais aparentes com o desenvolvimento infantil, além do pouco conhecimento sobre o desenvolvimento inicial dos bebês que recebem diagnostico. As limitações na identificação da detecção dos riscos ao autismo ainda residem, de acordo com as autoras:

(...) na busca de um conjunto de categorias comportamentais discretas cuja ausência revelaria o risco de autismo; no delineamento dos estudos com intervalos de observação muito longos, o que dificulta captar pequenas mudanças que ocorrem em intervalos curtos de tempo; na pouca ênfase em 
categorias afetivas e de interação, cujos déficits são marcantes no autismo; em análises pouco descritivas das características de interação entre bebê e adulto.

Garcia \& Lampreia (2011) falam que as possibilidades de identificação de risco para o autismo no primeiro ano parecem se expressar melhor na análise de categorias de interação e de ordem afetiva que sejam realizadas em observações mais intensas e frequentes; em avaliações qualitativas das categorias interativas e afetivas, tanto do bebê, como do adulto e da relação entre eles. Os instrumentos SEAL, IRDI e ADBB utilizam-se tanto de categorias interativas, como afetivas e foram criados com o intuito de serem aplicados em espaços de saúde, com encontros mais frequentes. Faz-se notar que os instrumentos aqui utilizados não têm nenhum propósito de realizar diagnóstico - todos detectam sinais, ou, segundo analogia feita pela Profa. Ana Paula Ramos, "fumaça" acerca de aspectos que não vão bem, de acordo com o que se espera em cada fase do desenvolvimento. Tal consideração não compromete o conceito de risco: "a probabilidade de um membro de uma população definida desenvolver uma dada doença em um período de tempo" (Almeida-Filho, 1989).

Talvez, para se captar de forma mais verídica estes sinais enunciativos, fosse necessário um acompanhamento mais intenso e frequente das díades, com uma periodicidade que pudesse dar conta das nuances desenvolvimentais ao longo dos meses da criança, conjuntamente à sua mãe. Os resultados apresentados foram obtidos somente em uma única avaliação, realizada a posteriori. Parece ser importante reavaliar as díades, a fim de que pequenas mudanças e nuances afetivas sejam melhor captadas. Sabemos que o processo de aquisição de linguagem está ligado às relações iniciais mãe-bebês, e quanto mais nos aproximarmos deste diálogo, mais conseguiremos identificar possíveis ausências e, consequentemente, evitar cristalização de sintomas, se feita intervenção a termo. Desta forma, pesquisas que caminhem em projetos de detecção e se utilizem de instrumentos que sinalizem dificuldades na primeiríssima infância se fazem de grande valor.

Retomando a trajetória da pesquisa, partiu-se inicialmente do resultado do item de vocalização da CIB, que nos indicou algo fora do esperado na literatura, no qual bebês irmãos de crianças com TEA acabaram por verbalizar mais do que as que não possuíam irmão com este diagnóstico. Não é novo saber que as vocalizações estão longe de abarcar a questão propriamente da linguagem; um bebê que vocaliza não está na linguagem se não houver uma intencionalidade 
comunicativa com o outro e se esta verbalização não se desenvolver em códigos comunicacionais estabelecidos, transformando-se em palavras convencionadas pela língua materna.

Talvez o resultado da CIB, usado como ponto de partida para esta dissertação, evocou ainda mais a complexidade do processo de aquisição de linguagem e, ao se estudar o desenvolvimento da linguagem em crianças até doze meses, a questão propriamente da verbalização não importe tanto enquanto variável isolada, apesar de ser um indicio importante da expressividade do bebê e como ele reage e se coloca no mundo, além de pesquisas ainda muito iniciais tenderem a observar a frequência deste fator como um sinal significativo em crianças que posteriormente foram diagnosticadas com TEA.

É importante ressaltar que filmagens de um único momento da díade nos dão uma delicada informação de como se relaciona a mãe e seu bebê, sendo um bom recurso para captar pormenorizadamente muitas nuances. Porém, se o intuito é aprofundar o olhar sobre cada díade, encontros com cada uma das famílias seriam importantes a fim de captarmos melhor esta informação e tercemos uma melhor análise acerca dos pontos estudados, adentrando mais no universo familiar e captando com mais singularidade cada nuance.

É de conhecimento a informação do quanto a presença de uma pesquisadora pode causar uma inibição maior às mães e seus bebês, sem contar que cada mãe sabia que a (s) pesquisadora (s) eram psicólogas, sendo cabível de instigar certas fantasias e provocar também alguma mudança ao modo de agir desta mãe, inibindo-a ou incitando-a a agir de forma mais mecanizada. A presença de um estranho, no caso, a pesquisadora (s) também pode alterar o comportamento dos bebês, além destes serem influenciados pelo estado emocional e ações maternas.

Sabe-se também das limitações de algumas das filmagens, que podem ter interferido de forma mais intensa nos resultados devido a dificuldades tanto no foco da díade (em um dos vídeos o rosto da mãe não é captado em muitos momentos, somente o da criança), como em outros nos quais interferências externas, como barulho ou presença de outras pessoas além das pesquisadoras no setting de filmagem, podem ter modificado a expressão dos resultados aqui avaliados.

Apesar destas dificuldades, as filmagens são recursos importantes para uma análise mais refinada dos dados, possível de se visualizar muitas vezes, com o intuito de discutir percepções, traçar análises mais assertivas e pormenorizadas e facilitar trocas entre a equipe. Além disto, as filmagens garantem a cegueira das pesquisadoras quanto ao grupo caso e controle no momento de avaliação do material. 
Dentro deste universo de considerações, realizarei abaixo a descrição de 1 cena filmada de uma dupla da segunda subfaixa do grupo controle que foi indicada somente com DL pelo SEAL, escolhida aleatoriamente dentre os casos. Priorizou-se a qualidade da filmagem, sem interferências de terceiros na cena e a captação nítida pela câmera das expressões materna e do bebê. Os 5 vídeos nos quais os bebês expressaram desconforto/choro também foram excluídos. A vinheta tem o intuito de nos aproximar dos resultados empíricos desta pesquisa que se apresentaram como proeminentes e contraditórios à literatura, com a intenção de tecermos considerações mais assertivas sobre nossos achados.

\section{A) Cena: Tânia e Fabi (8 meses)}

Tânia e Fabi estão sentadas uma de frente para outra em uma cama de casal, Fabi tem por entre as pernas uma cesta com brinquedos com algumas panelinhas de plástico, uma esponja, uma corrente com bolinhas de plástico (como as de enfeite de árvore de natal), uma pequena boneca e uma mamadeira, todo à disposição. A mãe pega uma das panelinhas e apresenta à filha, que pega com uma de suas mãos, a filha observa com o olhar. Tânia deixa as panelinhas de lado e apresenta à filha a boneca, colocando-a no colo de Fabi e dizendo com manhês: " a nenê, toma a nenê mãe, a nenê!! Ahh toma a nenê". Fabi corresponde o olhar da mãe e sorri, a mãe sorri alto de volta e reafirma "pega a nenê", aconchegando a boneca entre o corpo da filha e dizendo " $\tilde{a} \tilde{a} \tilde{a} \tilde{a}$ ", fazendo o movimento de deitar a boneca no colo de Fabi. A bebê sorri e tenta segurar a boneca com um de seus braços, no outro ainda segura uma panelinha, que não tirou da mão desde o início da filmagem. Tânia pega então a corrente de natal, sacudindo-a próxima à filha, que logo volta seu olhar à corrente, tentando pegá-la com uma das mãos. Fabi pega a corrente e a sacode no ar, abaixando-a até próximo do colchão da cama, a mãe então lhe apresenta a esponja, colocando-a próxima ao rosto de Fabi, dizendo "psiu!", a filha expressa-se com sorriso, bem baixinho "rah rah rah".

Com a mão que segura a panelinha, Fabi bate o brinquedo na cestinha de plástico, a mãe logo abre a cesta, sacode (os brinquedos fazem barulho) e diz "tó, brinca...". A mãe oferece à filha a esponja que está em suas mãos, a bebê pega, olhando para mãe. Deixa-a em sua frente e se volta à corrente, levantando-a no ar. A mãe pega uma colher de plástico na cesta "ó a colherzinha, ó, shiiiu”, sacudindo-a em frente à filha, que ainda fixa seu olhar à correntinha. A mãe bate a colher na panelinha que Fabi segura com uma de suas mãos, a filha olha para a cena, mas logo se volta 
para a corrente, balançando-a ainda no ar; a mãe diz "gostou, nê", pegando na correntinha e levando-a mais ao ar. Fabi e Tânia sacodem juntas e com vigor a corrente, a mãe larga o brinquedo e volta-se à boneca, dizendo "ó a nenê", e coloca o brinquedo próximo ao rosto da filha, encenando um beijo. A bebê põe o rosto da boneca na boca e expressa, também baixinho "rah rah", a mãe sorri e a bebê dirige seu olhar à câmera e bate a panelinha, que ainda não soltou de sus mãos, na cesta de plástico.

A mãe pega uma fraldinha e limpa a boca da filha, logo depois diz, balançando a mamadeira em frente à filha e colocando-a na boca da boneca: "toma, tó! Olha a mamadeirinha da nenê, ó ... Ó Fabi, da nenê, eeeee, toma", Fabi olha para a mamadeira, porém continua sacudindo a correntinha, que voltou a pegar. Tânia observa o movimento da filha, pega a corrente das mãos da filha e sacode forte, dando novamente à Fabi, que agarra forte a corrente e sacode a panelinha na cesta, fazendo barulho. "Bagunceira...", diz a mãe, abrindo a cesta e oferecendo outras panelinhas à filha, que continua com o olhar fixado na corrente de bolinhas. A mãe bate um panelinha naquela que Fabi está segurando, Fabi se expressa baixinho "hmmm", colocando a panelinha na boca, e logo a mãe diz "na boca não!", tirando o brinquedo do alcance da filha. Fabi e Mãe ficam com os olhares compartilhados entre as panelinhas, a boneca e a corrente, cada uma delas olha e interage com um brinquedo em momentos simultâneos e contínuos, porém ser haver encontro nas escolhas dos objetos.

A mãe tira a boneca do colo da filha, ajeitando-a ao lado e Fabi segue com o olhar "Olha e nenê!", diz a mãe, porém Fabi volta-se para as panelinhas, pegando uma em cada mão e levando uma delas à boca, "tira da bocaaa" diz a mãe. A bebê coloca outra panelinha na boca, a mãe diz “pisu!!", baixando o braço da filha. Continuam a interagir em momento quase seguidos com os três brinquedos, cada uma em um andamento, a atenção de Fabi fica partilhada.

A cena termina com a mãe voltando-se para a boneca e dizendo "olha a nenê, ó, olha Fabi, olha a nenê, ó"; Fabi está focada nas panelinhas e na corrente, a mãe então mexe em suas bochechas com um dos dedos, a fim de chamar a atenção da filha para a boneca, agora apontando para a mamadeira. Fabi fixa seu olhar na bebê com a mamadeira e a mãe diz "óóó a nenê, que lindo". Fim da cena.

A vinheta expressa momentos de encontros e desencontros entre mãe e filha. Fabi mostra-se disponível para interagir junto à sua mãe, respondendo com o olhar e sorrisos às intervenções 
materna e se sentindo chamada a brincar com aquilo que é apresentado pela mãe. Parece à vontade na cena, interessada em explorar com detalhes cada brinquedo e tirar proveito deste momento de encontro com os objetos e com Tânia. Está sentada na cama de casal, sua postura e forma de preensão dos brinquedos expressa um adequado desenvolvimento motor e tônico. Sua expressão na interlocução se atém aos sons não verbais, com 2 momentos de sorrisos (rah rah rah) e um breve resmungo ("hmmm").

Nos itens do SEAL que dizem respeito à criança, obteve ausentes no 2 - A criança preenche seu lugar na interlocução com sons verbais como vogais elou consoantes; 9 - A criança preenche seu lugar na interlocução (enunciado) com sons verbais (sílabas com vogais $e$ consoantes variadas - ao menos dois pontos e dois modos articulatórios de consoantes); 10 - A criança esboça a produção de protopalavras por espelhamento à fala da mãe (ou substituto) e 11 A criança esboça a produção de protopalavras espontaneamente.

A avaliação da especialista foi coerente e expressa aquilo que também pude observar na filmagem. Fabi, em nenhum momento, coloca-se por meio de sons verbais como vogal ou consoantes, nem mesmo o uso de protopalavras, compreendidas aqui enquanto formas com estabilidade fonética, com clara intenção comunicativa (ex: mamá, papá).

Tânia, na cena, realiza manhês adequado e parece sensível para captar alguns sinais e gostos da filha, verbalizando que a bebê gostou da corrente de bolinhas, mudando o rumo da brincadeira ao ver o olhar da bebê por um outro objeto e de cuidar de Fabi, quando observa que a mesma está com um pouquinho de baba na boca. Apesar disto, tem-se a impressão de certa ansiedade e invasividade na maior parte da interação. A mãe propõe muitas atividades, em um espaço pequeno de tempo, impedindo, muitas vezes, da filha se envolver profundamente em alguma brincadeira: parece haver uma confusão por entre os brinquedos, geradora de desencontros durante a interação.

Pelo SEAL, a mãe teve ausente o item 12 - Quando a mãe (ou substituta) é convocada a enunciar pela criança, a mesma reproduz seu enunciado e aguarda a resposta da criança. $\mathrm{Na}$ cena, Tânia até enuncia por Fabi, porém não consegue esperar a resposta da filha, já introduzindo seus conteúdos ou mudando o rumo da brincadeira para aquilo que lhe convém.

Esta ansiedade da Tânia pode ter sido gerada pelo momento da filmagem, como já discutido anteriormente, ou pode ser o retrato de um comportamento contínuo materno. Dentro desta última hipótese, este vínculo "barulhento" entre mãe e filha pode gerar reflexos na instauração de Fabi na linguagem, já que o ato de anunciação se encontra desencontrado, permeada por "ruídos": pelo 
excesso de estímulos de Tânia, Fabi não conseguiu espaço para se expressar verbalmente. Neste caso, a relação de conjunção e disjunção eu e tu são dificultadas pela impossibilidade materna de transformar em palavras as muitas das manifestações da bebê, por Tânia estar presa às suas necessidades, em grande parte das vezes. A mutualidade entre os locutores, ponto trazido por Winnicott, é o alicerce da comunicação da mãe com seu bebê, sendo a partir dela que a linguagem se desenvolverá. Se não houver esta sincronia, a entrada no simbólico será dificultada, gerando atrasos linguísticos.

Tânia e Fabi, em alguns momentos, apresentam sintonia e a mãe mostrou-se atenta às demandas da filha, porém fica a sensação de mais desencontros do que encontros, propriamente, apesar, é claro, de haver potência de mutualidade entre elas.

Neste caso, o SEAL foi eficaz na identificação de DL, já que houve desencontros entre e mãe e filha, com ausência de expressão verbal pela bebê e comportamento intrusivo materno. Como já elencado nesta discussão, seria necessário um acompanhamento da dupla para compreendermos melhor a situação desenhada, a fim de entendermos se a invasividade foi causada por uma ansiedade em decorrência da situação de filmagem, que resultou na não expressão verbal de Fabi ou se a dupla é permeada por estes desencontros, que estão causando atrasos nas expressões verbais da criança.

A exemplificação do caso expande a discussão dos resultados, porém o esclarecimento do aumento de DL no grupo controle, se comparado ao grupo caso, na segunda subfaixa ainda se mostra distante de conclusões assertivas, assegurando a necessidade de avaliação destas duplas em outros momentos.

A literatura aponta aumento de dificuldades de desenvolvimento, inclusive do processo de aquisição de linguagem em crianças mais velhas, porém sabemos que a disparidade entre as duas subfaixas apresentou-se neste trabalho de maneira estranha, já que a diferença entre elas foi muito alta. Cabe até levantar se é possível a comparação entre duas subfaixas onde o nível de exigência entre ambas se faz diferente, já que são exigidas mais competências das díades com idades de crianças maiores, do que as de menor idade, pautadas em teoria de desenvolvimento infantil desenvolvidas na dissertação. Este desnível no processo de avaliação dos requisitos invalidaria esta comparação, sendo necessária a construção de ouras métricas comparativas, a serem pesquisadas. 
Sem contar com as questões já abordadas a respeito das filmagens, que trariam possível inibição nas duplas e aqui, no caso, afetaram sobremaneira as relações entre mães e bebês da segunda subfaixa, se compararmos com as da primeira subfaixa. 


\section{CAPÍTULO 5: CONSIDERAÇÕES FINAIS}

Esta pesquisa surgiu da inquietação advinda de um resultado contrário à literatura, no qual crianças que possuíam um irmão mais velho com TEA (caso) verbalizaram mais do que crianças com o irmão mais velho sem o diagnóstico de TEA (controle), avaliadas a partir da CIB (Coding Interactive Behavior) e ADBB (Alarm Distress Baby Scale). Como hipótese inicial pensou-se sobre a não sensibilidade dos instrumentos para captar este aspecto. Meu caminho foi o de me aprofundar nas referências que diziam respeito ao universo da linguagem, a fim de compreender melhor o processo de aquisição linguística dentro de um panorama que dialogasse com a teoria do psicanalista Winnicott e com autores de desenvolvimento infantil, em crianças que possuíam um irmão mais velho com diagnóstico de TEA.

O arcabouço teórico trabalhou conjuntamente aos instrumentos escolhidos nas avaliações da amostra, na medida em que todos preconizavam itens que valorizavam a subjetividade do bebê e reciprocidade das interações entre mãe e filho. Winnicott, em especial, frisou a necessidade de um ambiente suportivo, capaz de dar conta das necessidades essenciais do bebê para que este desenvolva sua potencialidade de ser, sendo mais explorado nas análises qualitativas do que propriamente na discussão dos resultados empíricos. Ao longo do processo de escrita, percebeu-se dificuldade em encontrar justificativas para os dados na teoria winnicottiana, já que o autor utiliza conceitos pouco atualizados a respeito do autismo e por abordar a questão da linguagem mais centralizada nos aspectos comunicacionais entre mãe e filho. A necessidade de explorar outros autores psicanalíticos e da teoria enunciativa veio a partir desta constatação; porém a proposta de Winnicott vem agregar reflexões à pesquisa na primeira infância, trazendo a importância do ambiente no desenvolvimento humano e o cuidado na atenção às necessidades e competências do bebê.

As cenas transcritas a partir da teoria de Socha (2008) tiveram caráter elucidativo e nos aproximaram das relações íntimas duais e de possíveis entraves que podem se desenvolver, sendo necessário estarmos atentos a estas sutis, mas importantes nuances que aparecem nas relações.

Estas dificuldades podem acarretar tanto problemas de desenvolvimento psíquico, como dificuldades de mutualidade observadas qualitativamente nas díades apresentadas.

A principal hipótese do trabalho foi testar a concepção de que crianças do grupo caso teriam mais dificuldades no processo enunciativo de aquisição de linguagem, se comparadas às do grupo controle, o que não ocorreu como dado estatisticamente significante. 
Apesar disto, encontramos uma tendência a uma dificuldade de aquisição de linguagem na primeira subfaixa, dos 2 meses aos 6 meses e 29 dias, nas díades do grupo caso. Este resultado vai ao encontro da literatura e corrobora na reafirmação da condição de maiores dificuldades de desenvolvimento dos irmãos de crianças com TEA. Vale frisar que esta condição se expande não só à criança, mas à relação mãe-bebê, na qual a mãe ocupa um papel fundamental no processo de subjetivação infantil, podendo ser influenciada pelas dificuldades envolvidas em ter um filho com o diagnostico de autismo. Dentro desta mesma subfaixa de idade, houve associação entre Ñ-DL e ÑDD, além de Ñ-DL e SR. Encontrou-se também tendência do sexo feminino para não dificuldade no processo de aquisição de linguagem, se comparada aos meninos, indo ao encontro da literatura já descrita.

Para a segunda subfaixa, dos 7 meses aos 12 meses e 29 dias, obtivemos um resultado oposto à literatura, no qual díades do grupo caso tiveram menos dificuldades no processo de aquisição de linguagem avaliadas pelo instrumento SEAL do que díades do grupo controle (crianças sem irmão mais velho com TEA). Supõe-se que na medida em que os bebês se desenvolvem, são esperadas novas competências infantis, sendo necessário nestas crianças um repertório cada vez mais complexo a nível desenvolvimental, o que abriria espaço para a aparição de maiores problemas no desenvolvimento, que abarcam, inclusive, as dificuldades de linguagem. Mais pesquisas neste universo precisam ser desenvolvidas com o intuito de estudarmos melhor as especificidades de desenvolvimento, tanto psíquico, como linguístico nesta subfaixa, em especifico.

Na pesquisa da qual esta dissertação se deriva, os resultados da CIB dos compósitos que dizem respeito às qualidades maternas, nas díades de 12 a 24 meses, foram piores ao se comparar com as de até 12 meses de idade, com aumento da intrusividade, diminuição da sensibilidade e do limite. Este resultado nos alerta também sobre a condição destas mães e a importância de um olhar cuidadoso e atento às cuidadoras principais por parte dos órgãos de saúde, para diminuir o sofrimento destas mães, criando uma rede de apoio e acolhimento frente às demandas geradas.

Ao mesmo tempo, este achado nas díades da segunda subfaixa de idade, nos remete a questões metodológicas, tanto referentes à qualidade e forma de filmagem, já que se trata de uma base de dados secundária, que não teve um propósito inicial de avaliar aspectos de enunciação mais pormenorizados, como também à importância de uma segunda avaliadora cega frente aos grupos caso e controle, para validar o material com mais fidedignidade. 
O caso clínico brevemente exposto teve como finalidade ilustrar e fazer com que pudéssemos nos aproximar de uma das duplas, com o intuito de compreender o resultado empírico mais destoante deste trabalho. A vinheta alude ao universo subjetivo das díades da segunda subfaixa, do grupo controle, que foram avaliadas com DL pelo SEAL. Percebemos a não expressão verbal infantil durante a filmagem, que nos faz entrar tanto na hipótese de um possível atraso lingüístico, como das limitações da pesquisa, ao avaliar somente um único momento da criança. A análise da qualidade vocal materna e de suas competências na relação com seu bebê foram pontos valorizados, já que, como preconizado, a subjetivação infantil se dá sempre na relação com um outro. Aspectos linguísticos, de articulação verbal e uso de vogais e consoantes também puderam ser avaliados, sendo sua ausência, no caso, algo a se atentar, já que foge ao esperado.

Tivemos como desafio explicar dois resultados inesperados oriundos desta pesquisa: a disparidade entre as subfaixas de idade para dificuldade de linguagem e a elevada dificuldade de linguagem na segunda subfaixa em crianças do grupo controle, em comparação ao grupo caso. Nenhum dos caminhos foi conclusivo, fazendo com que fosse desenvolvido até um questionamento sobre métricas de comparabilidade entre as idades. As questões ainda se fazem inconclusivas, porém espera-se que os caminhos aqui desenvolvidos tenham auxiliado na expansão do conhecimento sobre esta temática.

Para além disto, a motivação do uso do SEAL partiu da importância de sinalizar possíveis dificuldades no processo enunciativo de linguagem, que se desdobram na construção de um olhar atento sobre este aspecto ao cuidarmos principalmente de duplas mãe-bebê em risco. No entanto, é precoce afirmar que o instrumento apresentou eficácia em nossa amostra na detecção dos sinais de dificuldades de linguagem, pois houve resultados inesperados, para os quais a literatura parece não tecer explicações, sendo necessário um acompanhamento destas díades no decorrer de seus desenvolvimentos, a fim de que houvesse mais certeza quanto aos resultados aqui encontrados.

Apesar dos resultados serem inconclusivos para a detecção de dificuldades de linguagem entre os grupos caso e controle em nossa amostra, em consideração à literatura, permanece uma recomendação de cuidado tanto para as mães como para estes bebês irmãos de crianças com TEA. Futuras pesquisas que se utilizem de instrumentos preditivos para linguagem, visando o caráter de aspectos da relação mãe e bebê trabalhados aqui, são importantes ao pensarmos no valor de instrumentos de avaliação para o estudo, prevenção e cuidado destas mães e seus filhos. 


\section{REFERÊNCIAS BIBLIOGRÁFICAS}

Agamben, G. (2007). Bartleby, escrita da potência. Lisboa: Assírio \& Alvim.

Almeida Filho, N. D. (1989). Epidemiologia sem números. Rio de Janeiro: Campus.

Alvarez, A. (1994). Companhia viva: psicoterapia psicanalítica com crianças autistas, borderline, carentes e maltratadas. Porto Alegre: Artes Médicas.

American Speech-Language-Hearing Association (2018). Homepage: https://www.asha.org/. Acesso em 17 de janeiro de 2019.

Anzieu, D.(1976). L'enveloppe sonore du soi. Nouvelle revue de psychanalyse, 13,173- 179.

Anzieu, D., \& Séchaud, E. (1994). Le moi-peau. Paris: Dunod.

Araújo, C. A. (2003). O autismo na teoria do amadurecimento de Winnicott. Natureza humana, 5(1), 39-58.

Araujo, G. X. (2010). Quando não há mais espaço-um estudo sobre a fratria das crianças autistas. Estilos da Clinica, 15(1), 126-143.

Araujo,G.D., \& Lerner,R .(2010). Discussão da noção de intersubjetividade à luz de contribuições da psicanálise. Reverso, 32(60), 35-42.

Bailey, A., Phillips, W., \& Rutter, M. (1996). Autism: towards an integration of clinical, genetic, neuropsychological, and neurobiological perspectives. Journal of Child Psychology and Psychiatry, 37(1), 89-126.

Baker-Ericzen,M.J.; Brookman-Frazee, L; \& Stahmer, A. (2005). Stress level and adaptability in parents of toddlers with and without autism spectrum disorders. Research and practice for persons with severe disabilities. 30(4), 194-204.

Benveniste, É. (1989). O aparelho formal da enunciação, in: Problemas de lingüística geral II, 3, 81- 92. 
Benveniste, É. (1995). Da subjetividade na linguagem, in: Problemas de linguística geral I, 3, 284293.

Bhat, S., Acharya, U. R., Adeli, H., Bairy, G. M., \& Adeli, A. (2014). Autism: cause factors, early diagnosis and therapies. Reviews in the Neurosciences, 25(6), 841-850.

Bick, E. (1991). A experiência da pele em relações de objeto arcaicas, in: Melanie Klein Hoje. Desenvolvimentos da teoria e da técnica, 1 .

Bion, W. (1991). Aprendendo com a experiência. Rio de Janeiro, Imago.

Bowlby, J. (1990). Apego. Segunda ed. São Paulo: Martins Fontes.

Cassel, T. D., Messinger, D. S., Ibanez, L. V., Haltigan, J. D., Acosta, S. I., \& Buchman, A. C. (2007). Early social and emotional communication in the infant siblings of children with autism spectrum disorders: An examination of the broad phenotype. Journal of autism and developmental disorders, 37(1), 122-132.

Cachapuz, R. F. (2006). A influência das variáveis ambientais no desenvolvimento da linguagem em uma amostra de crianças. Revista da AMRIGS, 50(4), 292-301.

Charman, T., \& Baird, G. (2002). Practitioner review: Diagnosis of autism spectrum disorder in 2-and 3-year-old children. Journal of Child Psychology and Psychiatry, 43(3), 289-305.

Cleland, J., Gibbon, F. E., Peppé, S. J., O'Hare, A., \& Rutherford, M. (2010). Phonetic and phonological errors in children with high functioning autism and Asperger syndrome. International Journal of Speech-Language Pathology, 12(1), 69-76.

Cohen, I. L., Sudhalter, V., Landon-Jimenez, D., \& Keogh, M. (1993). A neural network approach to the classification of autism. Journal of Autism and Developmental Disorders, 23, 443-466.

Crespin, G. (2004). A clínica precoce: o nascimento do humano. São Paulo: Casa do Psicólogo.

Crestani, A. H., de Mendonça Rosa, F. F., de Souza, A. P. R., Pretto, J. P., Moro, M. P., \& Dias, L. (2012). A experiência da maternidade e a dialogia mãe-filho com distúrbio de linguagem. Revista 
Cefac, 14(2).

Crestani, A. H., Souza, A. P. R. D., Beltrami, L., \& Moraes, A. B. D. (2012). Análise da associação entre tipos de aleitamento, presença de risco ao desenvolvimento infantil, variáveis obstétricas e socioeconômicas. J Soc Bras Fonoaudiol, 24(3), 205-10.

Crestani, A. H. (2012). Produção inicial de fala, risco ao Desenvolvimento Infantil e Variáveis Socieconômicas, Demográficas, Psicossociais e Obstétricas. Dissertação de mestrado. Universidade Federal de Santa Maria.

Crestani, A. H. (2016). Elaboração e validação de índices de aquisição da linguagem em uma perspectiva enunciativa para crianças de 2 a 12 meses. Tese de Doutorado. Universidade Federal de Santa Maria.

Durand et al., (2019). Infant Mental Health Journal, no prelo

Elsabbagh, M., Divan, G., Koh. Y. J., Kim, Y. S., Kauchali, S., Marcín, C., Montiel-Nava, C., Patel,V., Paula,C. S., Wang, C., Yasamy, M. T., \& Fombonne, E. (2012). Global Prevalence of Autism and Other Pervasive Developmental Disorders. Autism Res. 5, 160-179.

Facuri Lopes S.C., Ricas J., Mancini M.C. (2008). Evaluation of the psychometrics properties of the alarm distress baby scale among 122 Brazilian children, Infant Mental Health Journal; 29 (2): 153173.

Feldman, R. (1998). Coding interactive behavior manual. Manual não publicado. Bar-Ilan University, Israel.

Fernandes, F. D. M. (2003). Distúrbios da linguagem em autismo infantil. Fonoaudiologia informação para a formação: linguagem: desenvolvimento normal. Alterações e distúrbios. Rio de Janeiro: Guanabara Koogan.

Fernandes, F. D. M. (2009). Famílias com crianças autistas na literatura internacional. Rev Soc Bras Fonoaudiol, 14(3), 427-32.

Filipek, P. A., Accardo, P. J., Baranek, G. T., Cook, E. H., Dawson, G., Gordon, B., \& Minshew, 
N. J. (1999). The screening and diagnosis of autistic spectrum disorders. Journal of autism and developmental disorders, 29(6), 439-484.

Flax, J. F., Realpe-Bonilla, T., Hirsch, L. S., Brzustowicz, L. M., Bartlett, C. W., \& Tallal, P. (2003). Specific language impairment in families: Evidence for co-occurrence with reading impairments. Journal of Speech, Language, and Hearing Research, 46(3), 530-543.

Flores, M. R., Beltrami, L., \& de Souza, A. P. R. (2011). O manhês e suas implicações para a constituição do sujeito na linguagem. Distúrbios da Comunicação, 23(2).

Freud,S., \& de Souza, P. C. (2010). Obras Completas: Introdução ao narcisismo: ensaios de metapsicologia e outros textos (1914-1916). Companhia das Letras.

Fombonne, E. (2005). The changing epidemiology of autism. Journal of Applied Research in Intellectual Disabilities, 18(4), 281-294.

Fulgencio, L. (2008). O método especulativo em Freud. EDUC-Editora da PUC-SP.

Garcia, M. L., \& Lampreia, C. (2011). Limites e possibilidades da identificação de risco de autismo no primeiro ano de vida. Psicologia: Reflexão e Crítica, 24(2).

Gernsbacher, M. A., Stevenson, J. L., Khandakar, S., \& Goldsmith, H. H. (2008). Why does joint attention look atypical in autism?. Child Development Perspectives, 2(1), 38-45.

Geschwind, D.H. (2011). Genetics of Autism Spectrum Disorders. Trends in Cognitive Sciences, $15(9), 409-416$.

Goldberg, W. A., Jarvis, K. L., Osann, K., Laulhere, T. M., Straub, C., Thomas, E., \& Spence, M. A.(2005). Brief report: Early social communication behaviors in the younger siblings of children with autism. Journal of autism and developmental disorders, 35(5),657-664.

Griep, R. H., Chor, D., Faerstein, E., Werneck, G. L., \& Lopes, C. S. (2005). Validade de constructo de escala de apoio social do Medical Outcomes Study adaptada para o português no Estudo Pró-Saúde. Cadernos de Saúde Pública, 21, 703-714. 
Guedeney, A., Fermanian, J. (2001). A validity and reliability study of assessment and screening for sustained withdrawal reaction in infancy: the Alarm Distress Baby Scale. Infant Mental Health J. 22: 559-575.

Haag, G. (2008). Comment les psychanalystes peuvent aider les enfants avec autisme et leurs familles. In Autisme: état des lieux et horizons (pp. 119-143). ERES.

Hastings,R.; Kovshof, F., Ward, N., Espinosa, F., Brown, T., Remington, B. (2005). Systems analysis of stress and positive perceptions in mothers and fathers of pre-school children with autism. Journal of Autism and Developmental Disorders. 35(5), 635-544.

Hayes, S. A., \& Watson, S. L. (2013). The impact of parenting stress: A meta-analysis of studies comparing the experience of parenting stress in parents of children with and without autism spectrum disorder. Journal of autism and developmental disorders, 43(3),629-642.

Hoffman, C. D.; Sweeney, D. P.; Hodge, D.; Lopez-Wagner, M. C., \& Looney, L. (2009). Parenting stress and closeness mothering of typically developing children and mothers of children with autism. Focus on autism and other developmental disabilities. 24(3), 178-187.

Howlin, P., Goode, S., Hutton, J., \& Rutter, M. (2004). Adult outcome for children with autism. Journal of Child Psychology and Psychiatry, 45(2),212-22

Kasari, C., \& Sigman, M. (1997) Linking parental perceptions to interactions in young children with autism. Journal of Austism and developmental disorders.27(1), 39-57.

Klin, A. (1991). Young autistic children's listening preferences in regard to speech: a possible characterization of the symptom of social withdrawal. Journal of autism and developmental disorders, 21(1), 29-42.

Kruel, C. S., Rechia, I. C., Oliveira, L. D., \& Souza, A. P. R. (2016). Categorias enunciativas na descrição do funcionamento de linguagem de mães e bebês de um a quatro meses. CEP, 28(3), 244-251. 
Kupfer, M. C. M., Jerusalinsky, A. N., Bernardino, L. M. F., Wanderley, D., Rocha, P. S. B., Molina, S. E., \& Lerner, R. (2009). Valor preditivo de indicadores clínicos de risco para o desenvolvimento infantil: um estudo a partir da teoria psicanalítica. Lat. Am. Journal of Fund. Psychopath. Online, 6(1), 48-68.

Lacan, J. (1964). Le Séminaire, Livre XI, Les quatre concepts fondamentaux de la psychanalyse. Paris: Seuil, 1973.

Landa, R. (2007). Early communication development and intervention for children with autism. Mental retardation and developmental disabilities research reviews, 13(1), 16-25.

Landa, R.J., Gross, A.L., Stuart, E.A., \& Bauman, M. (2012). Latent class analysis of early developmental trajectory in baby siblings of children with autism. Journal of Child Psychology and Psychiatry, 53(9), 986-996.

Laznik-Penot, M. C. (1995). Vers la parole. Paris: Denoël.

Laznik, M C. (2004). A voz da sereia. Salvador: Ágalma.

Laznik, M. C., Maestro, S., \& Muratori, F. (2005). Interações sonoras entre bebês que se tornaram autistas e seus pais. Proceedings of the Colóquio franco-brasileiro sobre a clínica com bebês.

Lerner, R. (2011). Indicadores clínicos de risco para o desenvolvimento infantil-IRDI: verificação da capacidade discriminativa entre autismo, retardo mental e normalidade. Universidade de São Paulo.

Loparic, Zeljko. (2000). O "animal humano". Natureza humana , 2(2), 351-397.

Lord, C. (1995). Follow-up of two-year-olds referred for possible autism. Journal of child psychology and psychiatry, 36(8), 1365-1382.

Losapio, M. F., \& Pondé, M. P. (2008). Tradução para o português da escala M-CHAT para rastreamento precoce de autismo. Rev Psiquiatr Rio Gd Sul, 30(3), 221-9.

Malloch, S., \& Trevarthen, C. (2009). Musicality: Communicating the vitality and interests of 
life. Communicative musicality: Exploring the basis of human companionship, 1, 1-10.

Mahler, M., \& de Souza, H. M. (1982). O processo de separação-individuação. Porto Alegre: Artes Médicas.

Jesus Mari, J., \& Williams, P. (1986). A validity study of a psychiatric screening questionnaire (SRQ-20) in primary care in the city of São Paulo. The British Journal of Psychiatry, 148(1), 2326.

McNeill, D. (1985). So you think gestures are nonverbal? Psychological review, 92(3), 350.

Meltzer, D. (1984). A one-year-old goes to nursery: A parable of confusing times. Journal of Child Psychotherapy, 10(1), 89-104.

Meltzer, D. (1984). Les concepts d'identification projective (Klein) et de contenant-contenu (Bion) en relation avec la situation analytique. Revue française de psychanalyse, 2, 542-549.

Meltzer, D. (1986). Discussion of Esther Bick's paper 'Further considerations on the function of the skin in early object relations'. British Journal of Psychotherapy, 2(4), 300-301.

Messinger, D., Young, G. S., Ozonoff, S., Dobkins, K., Carter, A., Zwaigenbaum, L. \& Hutman, T. (2013). Beyond autism: a baby siblings research consortium study of high-risk children at three years of age. Journal of the American Academy of Child \& Adolescent Psychiatry, 52(3), 300-308.

Mitchell, S., Brian, J., Zwaigenbaum, L., Roberts, W., Szatmari, P., Smith, I., et al. (2006). Early language and communication development of infants later diagnosed with autism spectrum disorder. Journal of Developmental and Behavioral Pediatrics, 27, S69-S78.

Montes, G., \& Halterman, J. S. (2007). Psychological functioning and coping among mothers of children with autism: A population-based study. Pediatrics, 119(5), e1040-e1046.

Newschaffer, C., Croen L. A., Fallin M. D., Hertz-PicciottoI. Shedd-Wise K. M. (2012). Infant siblings and the investigation of autism risk factors. Journal of Neuro developmental Disorders, $4: 7$. 
Ogden, T. H. (1998). Reverie and interpretation. Northvale, NJ: Jason Aronson.

Oliveira, L. D., \& Ramos-Souza, A. P. (2014). O distúrbio de linguagem em dois sujeitos com risco para o desenvolvimento em uma perspectiva enunciativa do funcionamento de linguagem. Revista CEFAC, 16(5), 1700-1712.

Organização Mundial da Saúde. (1994). CID-10: Classificação Estatística Internacional de Doenças, Vol. 1. São Paulo: Edusp.

Osborne, L. A., \& Reed, P. (2010). Stress and self-perceived parenting behaviors of parents of children with autistic spectrum conditions. Research in Autism Spectrum Disorders, 4(3), 405-414.

Ozonoff, S., Young, G., Carter, A., Messinger, D., Yirmiya, N., Zwaigenbaum, L.et al. (2011). Recurrence Risk for Autism Spectrum Disorders: A Baby Siblings Research Consortium Study. Pediatrics.128, (3).

Palladino, R. R. R. (2007). A propósito dos indicadores de risco. Distúrbios da Comunicação. ISSN 2176-2724, 19(2).

Paschoal, L. P. (2016). Retraimento social em bebês: um estudo exploratório sobre os irmãos mais novos de crianças com transtorno do espectro do autismo. Universidade de São Paulo.

Paul, R., Fuerst, Y., Ramsay, G., Chawarska, K., \& Klin, A. (2011). Out of the mouths of babes: Vocal production in infant siblings of children with ASD. Journal of Child Psychology and Psychiatry, 52(5), 588-598.

Paula, C. S., Ribeiro, S. H., Fombonne, E., \& Mercadante, M. T. (2011). Brief report: prevalence of pervasive developmental disorder in Brazil: a pilot study. Journal of Autism and Developmental Disorders, 41(12), 1738-1742.

Pereira, A., Riesgo, R. S., \& Wagner, M. B. (2008). Childhood autism: translation and validation of the Childhood Autism Rating Scale for use in Brazil. Jornal de Pediatria, 84(6), 487-494.

Quintero, N., \& McIntyre, L. L. (2010). Sibling adjustment and maternal well-being: An examination of families with and without a child with a nautism spectrum disorder. Focus on 
autism and other developmental disabilities. 25(1), 37-46.

Ramos, A. P. (2013). A interpretância na articulação corpo linguagem na Clínica de Bebês. Comunicações Orais em: III Seminário Internacional Transdisciplinar de Clínica e Pesquisa sobre o Bebê - Paris. Promovido por Instituto Langage.

Rebelo, A. C., \& Vital, A. P. (2006). Desenvolvimento da linguagem e sinais de alerta: construção e validação de um folheto informativo. Re (habilitar) - Revista da ESSA, n. ${ }^{\circ}$ 2, Edições Colibri, 2006, pp. 69-98.

Rigolet, S. A. N. (1998). Para uma Aquisição Precoce e Optimizada da Linguagem: Linhas de Orientação para Crianças até aos 6 anos. Porto (Portugal): Porto Editora.

Ritvo, E. R., Freeman, B. J., Pingree, C., Mason-Brothers, A., \& Jorde,L. (1989). The UCLAUniversity of Utah epidemiological survey of autism: Prevalence. The American Journal of Psychiatry, 146(2), 194.

Rosolato, G. (1977). Lesh allucinations acoustico-verbal eset les champs perceptifs du corps. L'évolution psychiatrique, 3(2).

Safra, G. (2005). Curando com histórias. São Paulo: Edições Sobornost, 23.

Sandin, S., Lichtenstein, P., Kuja-Halkola, R., Larsson, H., Hultman, C. M., \& Reichenberg, A. (2014). The familial risk of autism. Jama, 311(17), 1770-1777.

Siegel, B., Vukicevic, J., Elliott, G., \& Kraemer, H. (1989). The use of signal detection theory to assess DSM-III-R criteria for autistic disorder. Journal of the American Academy of Child and Adolescent Psychiatry, 28, 542-548

Sifuentes,M., \& Alves Bosa, C. (2010). Criando pré-escolares com autismo: características e desafios da coparentalidade. Psicologia em estudo, 15(3).

Silva, C. L. C. A instauração da criança na linguagem: princípios para uma teoria enunciativa em aquisição da linguagem. Porto Alegre: 2007. (Tese) Doutorado em Teorias do Texto e do Discurso. Universidade Federal do Rio Grande do Sul, 2007. 
Sim-Sim, I. (1998). Desenvolvimento da linguagem. Lisboa: Editora Lisboa, 1998.

Sim-Sim, I., Silva, A. C., \& Nunes, C. (2008). Linguagem e comunicação no jardim-de-infância: textos de apoio para educadores de infância. Lisboa: Ministério da Educação- Direção Geral de Inovação e de Desenvolvimento Curricular.

Slade, A. (2009). Mentalizing the unmentalizable. Parenting children on the spectrum. Journal of infant, child and adolescent psychotherapy. 8(1).

Smalley, S. L. (1997). Genetic influences in childhood-onset psychiatric disorders: autism and attention-deficit/hyperactivity disorder. The American Journal of Human Genetics, 60(6), 12761282.

Socha, A. (2008). A função especular da voz materna e suas referências ao psiquismo e à constituição do si mesmo. Winnicott e-prints, 3(1E2), 1-12.

Sousa, E. C., Lima, F. T., Tamanaha, A. C., Perissinoto, J., Azevedo, M. F. D., \& Chiari, B. M. (2009). A associação entre a suspeita inicial de perda auditiva e a ausência de comunicação verbal em crianças com transtornos do espectro autístico. Revista da Sociedade Brasileira de Fonoaudiologia.

Spitz, R. A., \& da Rocha, E. M. B. (1998). O primeiro ano de vida. São Paulo: Martins Fontes.

Sullivan, M., Finelli, J., Marvin, A., Garrett-Mayer, E., Bauman, M., \& Landa, R. (2007). Response to joint attention in toddlers at risk for autism spectrum disorder: A prospective study. Journal of autism and developmental disorders, 37(1), 37-48.

Szejer, M. (1999). Palavras Para Nascer a Escuta Psicanalitica Na Maternidade. São Paulo: Casa do Psicólogo.

Tager-Flusberg, H., Paul, R. \& Lord, C. (2005). Language and communication in autism. Handbook of autism and pervasive developmental disorders, 1, 335-364.

Taylor, J. L., \& Warren, Z. E. (2012). Maternal depressive symptoms following autism spectrum diagnosis. Journal of autism developmental disorder. 42(7), 1411-1418. 
Teixeira Caldas Campana, N., \& Lerner, R. (2014). Trocas alimentares entre bebês irmãos de autistas e suas mães: risco ou recurso?.Revista Latinoamericana de Psicopatologia Fundamental, 17(2).

Tustin, F. (1984). The growth of understanding. Journal of Child Psychotherapy, 10(2), 137-149.

Tustin, F. (2018). Autism and childhood psychosis. Routledge.

UNESCO (2002). Organização para a cooperação econômica e o desenvolvimento. Ministério da Saúde. Educação e cuidado na primeira infância: grandes desafios. Brasília: Unicef.

Volkmar, F., Chawarska, K., \& Klin, A. (2005). Autism in infancy and early childhood. Annu. Rev. Psychol., 56, 315-336.

Wing, L., \& Wing, J. K. (Eds.). (1976). Early childhood autism: Clinical, educational, and social aspects. Pergamon.

Winnicott, D. W. (1975 [1967]). O Papel de Espelho da Mãe e da Família no Desenvolvimento Infantil. In: O Brincar e a Realidade. Rio de Janeiro. Imago.

(1982 [1951]). Objetos transicionais e fenômenos transicionais. In: Da pediatria à psicanálise. Obras escolhidas. (Trad. Jane Russo, pp. 316-331). Rio de Janeiro: F Alves.

(1982). Visitando crianças hospitalizadas. In: A criança e seu mundo. 6a ed. Rio de Janeiro: Guanabara Koogan.

(1983). O ambiente e os processos de maturação. Porto Alegre. Artes Médicas.

(1990). Natureza humana. Rio de Janeiro. Editora Imago.

(1994 [1989a]). A experiência mãe-bebê de mutualidade. In: Explorações psicanalíticas. Porto Alegre: Arte Médicas. 
(2000 [1951]). Psicoses e cuidados maternos. In: Da pediatria à psicanálise.

Obras escolhidas. Rio de Janeiro: Imago.

(2006 [1987a]). Os bebês e suas mães. São Paulo: Martins Fontes. 